

\section{ИНТЕРНАУКА \\ in ternauka.org}

\section{ПЕДАГОГИКА И ПСИХОЛОГИЯ В COBPEMЕННОМ МИРЕ: ТЕОРЕТИЧЕСКИЕ И \\ ПРАКТИЧЕСКИЕ ИССЛЕДОВАНИЯ}

Сборник статей по материалам XLV международной научно-практической конференции

№ 3 (45)

Март 2021 г.

Издается с июля 2017 года

Москва

2021 


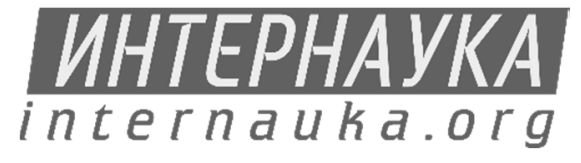

\title{
PEDAGOGY AND PSYCHOLOGY IN THE MODERN WORLD: THEORETICAL AND PRACTICAL RESEARCH
}

Proceedings of XLV international scientific-practical conference

\author{
№ 3 (45) \\ March 2021
}

Published since July 2017 
УДК 37.01

ББК 74.00

П24

П24 Педагогика и психология в современном мире: теоретические и практические исследования. сб. ст. по материалам XLV междунар. науч.-практ. конф. - № 3 (45). - М., Изд. «Интернаука», 2021. - $134 \mathrm{c}$. 


\section{Оглавление}

Доклады конференции на русском языке 8

Педагогика 8

Секция 1. Коррекционная педагогика 8

АДАПТАЦИЯ ПЕРВОКЛАССНИКОВ К ОБУЧЕНИЮ 8

В МУЗЫКАЛЬНОЙ ШКОЛЕ

Бажина Дарья Юрьевна

ПОВЫШЕНИЕ ЭФФЕКТИВНОСТИ УСВОЕНИЯ

12

СОЦИАЛЬНОГО ОПЫТА ПОСРЕДСТВОМ КОРРЕКЦИИ

ДЕЗАДАПТИВНОГО ПОВЕДЕНИЯ РЕБЁНКА С РАС

Пахомов Илья Александрович

Макарова Людмила Николаевна

Секция 2. Общая педагогика, история педагогики и образования

ЭФФЕКТИВНЫЕ МЕТОДЫ И ПРИЕМЫ СОЗДАНИЯ

ПРОБЛЕМНЫХ СИТУАЦИЙ НА УРОКАХ МАТЕМАТИКИ, ПРИ ОТКРЫТИИ НОВОГО ЗНАНИЯ В 5 КЛАССАХ

Гришаева Светлана Алексеевна

ОПТИМАЛЬНЫЕ СПОСОБЫ ВЗАИМОДЕЙСТВИЯ

И КОММУНИКАЦИИ В ПРОЦЕССЕ УЧЕБНО-

ПЕДАГОГИЧЕСКОЙ ДЕЯТЕЛЬНОСТИ

Лазарева Людмила Петровна

\section{Секция 3. Теория и методика обучения и воспитания}

ОПЫТ РАБОТЫ ПО ФОРМИРОВАНИЮ ОСНОВ

ГРАЖДАНСТВЕННОСТИ У ДЕТЕЙ СТАРШЕГО ДОШКОЛЬНОГО ВОЗРАСТА

Александрова Илона Викторовна

МАЛЫЕ ЖАНРЫ ФОЛЬКЛОРА КАК ИНСТРУМЕНТ

ФОРМИРОВАНИЯ КОММУНИКАТИВНОЙ КОМПЕТЕНЦИИ

ПРИ ИЗУЧЕНИИ РКИ

Астафурова Маргарита Владимировна

КОМПОЗИЦИЯ ПЕДАГОГИЧЕСКОГО ИЗМЕРЕНИЯ

ДЛЯ УРОКОВ АНГЛИЙСКОГО ЯЗЫКА

Буслаева Тамила Хабировна

Максимова Юлия Олеговна 
КОНЦЕПЦИИ, МЕТОДЫ И СПЕЦИФИКА ПЕДАГОГИКИ

В МУЗЫКАЛЬНОЙ ШКОЛЕ

Гильманова Гузель Забировна

СТРАТЕГИИ ОБУЧЕНИЯ КАК ВАЖНОЕ УСЛОВИЕ

48

ДЛЯ РАЗВИТИЯ АВТОНОМНОГО ОБУЧЕНИЯ

Мирзаев Дилмуроджон Тулкинжон угли

Гиздулин Эльдар Фатихович

\section{Секция 4. Теория и методика профессионального образования}

СОВРЕМЕННЫЕ ТРЕБОВАНИЯ К КАЧЕСТВУ

52

ОБРАЗОВАНИЯ В КОЛЛЕДЖАХ И УРОВЕНЬ ОСВОЕНИЯ

ПРОФЕССИОНАЛЬНЫХ КОМПЕТЕНЦИЙ

ВЫПУСКНИКОВ

Богданов Ренат Анверович

СИСТЕМА РЕЙТИНГОВОЙ ОЦЕНКИ КАЧЕСТВА ЗНАНИЙ СТУДЕНТОВ

Горбунова Татьяна Валерьевна

ПРИМЕНЕНИЕ ИННОВАЦИОННЫХ МЕТОДИК

И ТЕХНОЛОГИЙ КАК НЕОБХОДИМОЕ УСЛОВИЕ

ПОДГОТОВКИ ВОЕННОГО СПЕЦИАЛИСТА

Дубинина Елена Александровна

ВОВЛЕЧЕНИЕ БУДУЩИХ БАКАЛАВРОВ СОЦИАЛЬНОЙ

РАБОТЫ В СОЦИАЛЬНО-ПРОЕКТНУЮ ДЕЯТЕЛЬНОСТЬ ДЛЯ ФОРМИРОВАНИЯ У НИХ ПЕДАГОГИЧЕСКОЙ КУЛЬТУРЫ

Ибрагимов Юсуп Муслимович

НЕОБХОДИМОСТЬ РАЗВИТИЯ ТЕРМИНОЛОГИЧЕСКОЙ КОМПЕТЕНЦИИ В ПРОЦЕССЕ ОБУЧЕНИЯ

АНГЛИЙСКОМУ ЯЗЫКУ СТУДЕНТОВ МЕДИЦИНСКИХ СПЕЦИАЛЬНОСТЕЙ

Киселёва Дарья Олеговна

ПЕДАГОГИЧЕСКОЕ РУКОВОДСТВО

САМОСОВЕРШЕНСТВОВАНИЕМ ОФИЦЕРОВ КАК ОДНО

ИЗ УСЛОВИЙ ЭФФЕКТИВНОЙ ДЕЯТЕЛЬНОСТИ

КОМАНДИРА

Краснова Марина Васильевна

Проняева Елена Вячеславовна 
ПРОБЛЕМЫ ОРГАНИЗАЦИИ ИНДИВИДУАЛЬНЫХ РАБОТ

СТУДЕНТОВ ПО МАТЕМАТИКЕ

Нишонов Фарход Мусажонович

ОСОБЕННОСТИ И СПЕЦИФИКА ПРОФЕССИОНАЛЬНОГО 86

РОСТА ПРЕПОДАВАТЕЛЕЙ СИСТЕМЫ СРЕДНЕГО

ПРОФЕССИОНАЛЬНОГО ОБРАЗОВАНИЯ

Узунова Галина Петровна

\section{Психология}

Секция 5. Социальная психология

ПСИХОЛОГИЧЕСКИЕ УСЛОВИЯ УСПЕШНОЙ АДАПТАЦИИ 91 ПОДРОСТКОВ-МИГРАНТОВ

Родин Фаина

Conference papers in English

Pedagogy

Section 1. General pedagogics, pedagogics and formation history

EDUCATION OF THE DOMESTIC SPIRIT OF STUDENTS

OF PROFESSIONAL EDUCATIONAL INSTITUTIONS

Komil Abdullaev

THE ROLE OF HISTORICAL ARCHITECTURAL

MONUMENTS IN THE FORMATION OF NATIONAL PRIDE

BY PRESCHOOL ADULT CHILDREN

Shakhnoza Khasanova

Қазақ тіліндегі конференция баяндамалары

\section{Психология}

\section{1-Бөлім. Педагогикалық психология}

ЖЕКЕ ТҰЛҒАНЫҢ ТАНЫМДЫҚ ҮРДІСТЕРІНІҢ ДАМУЫ

МЕН КАЛЫПТАСУЫНЫҢ МҮМКІНДІКТЕРІ

Әліпбек Ардақ Зәуірбекқызы

Бахрамова Гульмира Абдурасуловна

Джанибекова Мухлиса Мирзакаримовна

Жәнділла Қайнар Серікұлы 
ЖАС ҰРПАҚТЫ ҰЛТТЫҚ БІРЕГЕЙЛІКТІ САҚТАУҒА

ТӘРБИЕЛЕУДІҢ МҮМКІНДІКТЕРІ

Қойшиев Қалдан Елеуұлы

Әліпбек Ардақ Зәуірбекқызы

Танабаева Гульмира Тулебаевна

Ибрай Еңлік Ибрайқызы

ОҚУШЫЛАРДЫҢ ЛИДЕРЛІК ҚАСИЕТІН ТӘРБИЕЛЕУДІҢ

МҮМКІНДІКТЕРІ

Әліпбек Ардақ Зәуірбекқызы

Сманов Ілесхан Сманович

Амирханова Гулимжан Нурадиновна

Искендар Марат Оралбекұлы

O'zbek tilidagi konferentsiya ma'ruzalari

Pedagogika

1 -Bo'lim. General pedagogika, pedagogika va ta'lim tarixi

TALABALARDA AKADEMIK MOBILLIKNI RIVOJLANTIRISH

Shermanova Diyora Shakarboyevna

2-Bo'lim. Kasb ta’limi nazariyasi va metodikasi

AMALIY MASHG'ULOTLARDA SIMULYATORLAR BILAN ISHLASH

Musamedova Kamola Abdulxakovna 


\title{
ДОКЛАДЫ КОНФЕРЕНЦИИ НА РУССКОМ ЯЗЫКЕ
}

\author{
ПЕДАГОГИКА
}

\author{
СЕКЦИЯ 1.
}

\section{КОРРЕКЦИОННАЯ ПЕДАГОГИКА}

\section{АДАПТАЦИЯ ПЕРВОКЛАССНИКОВ К ОБУЧЕНИЮ В МУЗЫКАЛЬНОЙ ШКОЛЕ}

Бажнина Дарья Юрьевна преподаватель по классу фортепиано, кониертмейстер, КГКП «Татарская школа искусств», Республика Казахстан, г. Семей

Адаптация в музыкальной школе - перестройка познавательной, мотивационной и эмоционально-волевой сфер ребенка при переходе к систематическому организованному школьному обучению. Основными особенностями систематического школьного обучения являются следующие. Во-первых, с поступлением в музыкальной школу ребенок начинает осуществлять общественно оцениваемую деятельность - учебную деятельность. Во-вторых, особенностью систематического школьного обучения является то, что оно требует обязательного выполнения ряда для всех одинаковых правил, которым подчинено все поведение ученика во время его пребывания в музыкальной школе. Благополучное сочетание социальных внешних условий ведет к адаптированности, неблагополучное - к дезадаптации.

Существует несколько уровней адаптации:

1. Высокий уровень. Первоклассник положительно относится к музыкальной школе, предъявляемые требования воспринимает адекватно; учебный материал усваивает легко; глубоко и полно овладевает программным материалом; прилежен; внимательно слушает указания объяснения 
учителя; выполняет поручения без внешнего контроля; проявляет большой интерес к самостоятельной учебной работе. Общественные поручения выполняет охотно и добросовестно; занимает в классе благоприятное статусное положение. Причем исходя из данных некоторых исследователей большинство шестилетних первоклассников не может иметь высокий уровень адаптации в силу неразвитости таких аспектов адаптации, как готовность к школьному обучению (по параметрам произвольности поведения, способности к обобщению, учебной мотивации и др.), несформированность личностных новообразований кризиса 7 лет (самооценка и уровень притязаний) без необходимого вмешательства педагогов и психологов.

2. Средний уровень. Первоклассник положительно относится к школе, ее посещение не вызывает отрицательных переживаний, понимает учебный материал, если учитель излагает его подробно и наглядно, усваивает основное содержание учебных программ, внимателен при выполнении заданий, поручений, указаний взрослого, но при его контроле; бывает сосредоточен только тогда, когда занимается чем-то, что ему интересно, общественные поручения выполняет добросовестно, дружит со многими одноклассниками.

3. Низкий уровень адаптации. Первоклассник отрицательно относится к школе; нередки жалобы на нездоровье; доминирует подавленное настроение; наблюдается нарушение дисциплины; объясняемый учителем материал усваивает фрагментарно; самостоятельная работа затруднена; при выполнении самостоятельных учебных заданий не проявляет интереса; к урокам готовится нерегулярно; необходимы постоянный контроль, систематические напоминания и побуждения со стороны учителя и родителей; сохраняет работоспособность и внимание при удлиненных паузах для отдыха, общественные поручения выполняет под контролем, без особого желания, пассивен; близких друзей не имеет, знает по именам и фамилиям лишь часть одноклассников.

4. Дезадаптация. Это отклонения в школьной деятельности затруднения в учебе, конфликты с одноклассниками, учителями. Школьная дезадаптация - это образование неадекватных механизмов приспособления ребенка в школе в форме нарушений учебы, поведения, конфликтных отношений, психогенных заболеваний и реакций, повышенного уровня тревожности, искажений в личностном развитии.

Существует три дезадаптационных стиля: Аккомодационный ребенок стремиться полностью подчинить свое поведение требованиям среды, ассимиляционный - ребенок стремится подчинить социальную среду своим потребностям. Незрелый - связан с психологической незрелостью ребенка и проявляется в неспособности его к принятию 
новой социальной ситуации развития. Повышенная степень выраженности каждого из этих стилей приспособления ведет к школьной дезадаптации.

Для многих детей поступление в школу может стать трудным испытанием. Хотя бы с одной из следующих проблем сталкивается каждый ребенок:

- режимные трудности (они заключаются в относительно низком уровне произвольности регуляции поведения, организованности);

- коммуникативные трудности (чаще всего наблюдаются у детей, имеющих малый опыт общения со сверстниками, проявляются в сложности привыкания к классному коллективу, к своему месту в этом коллективе);

- проблемы взаимоотношений с учителем;

- проблемы, связанные с изменением семейной обстановки.

Таким образом успешность адаптации зависит от уровня развития интеллектуальных функций, эмоционально-волевой сферы, сформированности коммуникативных навыков и т.д. Незрелость какой-либо из указанных сфер является одной из причин, которая может привести к той или иной форме дезадаптации.

\section{Особенности первоклассника-музыканта}

Главная особенность детей-первоклассников - первичное осознание позиции школьника, прежде всего через новые обязанности, которые ребенок учится выполнять. Ребенок убежден в том, что у него все должно получаться хорошо, поэтому сильно переживает свои неудачи, не всегда понимает их причины.

Учебная деятельность эффективнее осуществляется в условиях игры, наличия элементов соревновательности. Первоклассник хорошо запоминает, когда не только слышит информацию, но и видит ее наглядное отображение, имеет возможность потрогать носитель информации.

Внимание и память в основном не произвольны, то есть для концентрации ребенку требуется внешняя помощь (интересные картинки, звуковые сигналы, игровые ситуации). Внимание во многом определяется темпераментом. В силу этого отвлекаемость во время выполнения заданий довольно высокая, а контролировать свои действия (например, проверитьналичие ошибок в разборе нотного текста) малыш умеет плохо.

\section{Правила успешной адаптации первоклассников-музыкантов для родителей}

Поступление ребенка в музыкальную школу - это принципиально новый этап его жизни. Наиболее трудным для него является период 
адаптации к школе. Родителям надо быть готовыми к тому, что период адаптации может затянуться на несколько месяцев. Ребенку нужна помощь и, в первую очередь, он нуждается в поддержке самых близких ему людей - родителей.

Главная забота родителей в период адаптации первоклассника к школе - поддержание и развитие стремления учиться, узнавать новое. Ваше участие и интерес положительно скажутся на развитии познавательных способностей ребёнка. И эти способности вы также сможете ненавязчиво направлять и укреплять в дальнейшем.

Не сравнивать ребёнка с одноклассниками в музыкальной школе. Уважайте индивидуальность своего ребёнка, любите и принимайте его таким, какой он есть. Сравнивайте его собственные успехи.

С пониманием относитесь к тому, что у вашего малыша что-то не получается, даже если это кажется вам элементарным. Ваш ребенок не сможет сразу научиться играть как профессиональный музыкант. Запаситесь терпением. Помните, что высказывания типа: «Ну, сколько раз тебе повторять? Когда же ты, наконец, научишься?» и т.п. - кроме раздражения с обеих сторон, ничего не вызовут. Лучше поддерживайте, подбадривайте ребенка. Показываете, что вы верите в его силы, что у него все получится, и он всего добьется.

Музыкальная школа является дополнительным образованием, но это не кружок, а именно школа. С первых дней необходимо настроить ребенка на серьезное отношение к посещению школы. Как известно, лучший прием воспитания это собственный пример, поэтому от Вашего отношения к музыкальной школе, будет зависеть отношение к ней вашего ребенка. Если вы будете интересоваться классической, живой музыкой, то и ваш ребенок будет увлечен ей. Слушайте такую музыку дома, смотрите и посещайте концерты классической музыки.

Самая главная цель родителей в этот период - дать ребенку опыт самостоятельной работы, с первых же дней внушая, что только он сам ответственен за то, что происходит с ним в школе. Это очень важно на этой, самой главной ступеньке во взрослую жизнь. И ребенок в силу своих возрастных особенностей уже вполне способен принять и понять эту ответственность.

Не следует все время делать уроки вместе с ребенком. Иначе потом, когда вы придете с работы, окажется что он не занимался, т.к. взрослых не было дома.

Не стоит регулярно проверять домашнее задание, если ребенок сам об этом не попросит. Если вы сами окончили музыкальную школу, то ваша помощь может понадобиться ребенку, но это не должно быть систематически, потому что ребенок переложит ответственность за свои ошибки на ваши плечи. 
Не стоит интересоваться только отметками в музыкальной школе, лучше спросить, что сегодня было интересного в школе, что нового он узнал, что ему больше всего нравится в школе.

Первое время необходимо все таки ненавязчиво контролировать выполнение домашних заданий по музыке, пока ребенок не привыкнет к новому режиму дня. А режим дня должен быть у школьника обязательно. И даже если ваш ребенок уже не первоклассник в общеобразовательной школе и у него уже выработался свой режим, то с поступлением в музыкальную школу необходимо внести соответствующие изменения в его режим.

\section{Список литературы:}

1. А.Д. Лазарева. Пособие для преподавателей детей и родителей «Учимся играя».

2. Кузин. методическое пособие «Доинструментальный период».

3. Т.А. Рокитянская методическое пособие «Воспитание чувства ритма».

4. Р.Н. Бажилин «Школа игры на аккордеоне».

5. В. Семёнов «Современная школа игры на баяне».

6. В.В.Ушенин. «Школа художественного мастерства баяниста».

7. Кирнарская Д.К. статья: "Музыкальные способности", "10 причин отдать ребенка в музыкальную школу".

\section{ПОВЫШЕНИЕ ЭФФЕКТИВНОСТИ УСВОЕНИЯ СОЦИАЛЬНОГО ОПЫТА ПОСРЕДСТВОМ КОРРЕКЦИИ ДЕЗАДАПТИВНОГО ПОВЕДЕНИЯ РЕБЁНКА С РАС}

Пахомов Илья Александрович научный сотрудник, Тамбовский государственный университет им. Г.Р. Державина, $P \Phi$, г. Тамбов

Макарова Людмила Николаевна

д-р пед. наук, проф., Тамбовский государственный университет им. Г.Р. Державина, $P \Phi$, г. Тамбов 


\begin{abstract}
АННОТАЦИЯ
В публикации речь идёт о практическом случае коррекции дезадаптивных вокализаций ребёнка с РАС, осуществлявшейся средствами прикладного анализа поведения в рамках работы над созданием условий для эффективного наполнения социального опыта дошкольников, обучающихся в инклюзивной группе. Конкретно описана процедура дифференциального подкрепления альтернативных реакций. Приведён график, демонстрирующий динамику альтернативных и нежелательных реакций на разных этапах реализации процедуры. Сделаны соотвествующие выводы.
\end{abstract}

Ключевые слова: фазовые характеристики, цепь.

Введение. Формирование среды, способствующей эффективному наполнению социального опыта дошкольников, представляет собой одну из основных задач дошкольного педагога (как коррекционного, так и общей направленности) [2]. В условиях инклюзивных групп формирование такой среды может значительно затрудняться в том случае, если у кого-то из инклюзируемых детей присутствуют дезадаптивные (нежелательные) формы поведения [1]. К таковым можно отнести те поведения, которые значимо ухудшают уровень функционирования самого человека или его окружения. Наиболее яркими примерами однозначно нежелательных поведений являются агрессивное поведение, самоагрессивное поведение и деструктивное поведение. При этом в контексте работы над формированием социального опыта в качестве нежелательных реакций можно рассматривать те реакции, которые делают невозможными или значительно затрудняют обучающие мероприятия или социальную игровую деятельность. В данной публикации мы рассмотрим практический случай успешной коррекции социально-дезадаптивного поведения ребёнка с РАС посредством дифференциального подкрепления альтернативных реакций.

Участник и среда. Света - девочка 5 лет с диагнозом расстройство аутистического спектра (имя ребёнка изменено из соображений конфиденциальности, но прочая информация подана без искажений). Словарный запас близок к возрастной норме, но функциональное использование речи может вызывать затруднения. Девочка обучается в комбинированной (инклюзивной) группе ДОО без отдельного сопровождающего (тьютора или ассистента). При этом на время реализации процедуры коррекции нежелательного поведения (НП) индивидуальное сопровождение девочке потребовалось. Его осуществлял отдельный педагог, имеющий квалификацию в области применения прикладного анализа 
поведения в работе с детьми, имеющими поведенческие (эмоциональноволевые) особенности развития.

Целевое поведение. В качестве целевого поведения были взяты громкие вокализации, возникавшие в процессе продуктивной деятельности (такой как совместная творческая деятельность под руководством педагога, совместное конструирование, организованное педагогом и т.п.). Вокализации были в основном беспорядочными: могли содержать различимые слова или просто представлять собой наборы звуков. Возникали вокализации, в основном, в ситуациях при предъявлении немотивационных (слишком сложных для девочки или не совпадающих с выбранной ей последовательностью действий) инструкций педагога. После вокализаций инструкция, в основном снималась. Кроме того, ученице предоставлялось внимание (вопросы и «успокаивание» от педагога, а также внимание со стороны других детей группы). Учитывая то, что взаимодействие детей друг с другом не запрещалось в рамках рассматриваемой продуктивной деятельности, мы сделали предположение, что привлечение внимания может являться основной функцией НП с низкой вероятностью. На основании этих соображений нами был сделан предварительный вывод о том, что в функциональном смысле нежелательное поведение носит функцию избегания.

Материалы. В качестве материалов для обучения использовался тот инвентарь, с которым, в основном, проходит совместная продуктивная деятельность (пластилин, краски, карандаши, фломастеры, ножницы, клей, бумага, детали конструкторов, игровые наборы «Семья», «Автодок» и т.д.). Кроме того, на этапе формирования альтернативной реакции использовалась визуальные подсказки (карточки с надписью «я хочу сделать по-своему» и соответствующей иконкой-символом). Так как сама продуктивная деятельность является мотивационной для девочки, в качестве поощрений использовались, в основном, социальные поощрение (похвала и тактильные интеракции), в рамках некоторых заданий использовалась жетонная система поощрений с последующими сенсорными интеракциями (щекотка, поднимание вверх, кружение, объятия и т.п.).

Процедура. Обучение происходило в три этапа: индивидуальная работа с неограниченным количеством избеганий, индивидуальная работа с ограниченным количеством избеганий, групповая работа с ограниченным количеством избеганий. Дифференциальное подкрепление альтернативных реакций предполагало на фоне гашения нежелательных реакций (после возникновения целевых вокализаций требования не снимались, а продолжали предъявляться, при необходимости с использованием физических подсказок) возможность девочкой избежать требования 
посредством фразы «я хочу сделать по-своему», которая сопровождалась передачей ей карточки с данной надписью педагогу. На первом этапе таких карточек было неограниченное количество (на столе лежало 5 карточек, при этом педагог после получения карточки возвращал её в соответствующую стопку).

Для вызова альтернативной реакции использовалась жестовая подсказка (указывание пальцем на карточку с надписью), которую педагог предоставлял после возникновения «предшественников нежелательного поведения» (за несколько секунд до целевых вокализаций девочка начинала ёрзать на стуле и смотреть попеременно то на материалы, то на педагога). После слов «я хочу сделать по-своему» педагог сразу снимал требование и позволял девочке продолжить так, как она хочет.

На втором этапе количество «билетов на избегание» было снижено до 2 за одну процедуру. То есть за рисование, например, одного домика или сбор одного сюжета из игрушек ученица могла использовать карточку только два раза, а затем педагог в случае проговаривания Светой соответствующей фразы указывал на пустое место на столе и говорил «билетов не осталось, нужно сделать как просят».

Данные собирались подсчётом количество реакций (нежелательных и альтернативных) за первую пробу в день. Первая проба предполагала продуктивную деятельность, состоящую из не менее, чем 10 этапов (например, рисунок, предполагающий не менее 10 образцов от педагога или построение сюжета из игрушек, предполагающий не менее 10 просьб педагога). Полученные данные визуализированы в графике (рисунок 1).

Выводы. Визуальный анализ графика демонстрирует то, что уже к 4 сессии количество нежелательных поведений было доведено до нуля, но при этом количество альтернативных реакций было осталось стабильно большим (5-6). Начало второго этапа спровоцировало сильное увеличение количества нежелательных реакций, что может быть объяснено феноменом поведенческого взрыва (возникшего из-за того, что функция альтернативного поведения начала выполняться в ограниченном количестве раз). Тем не менее, уже через 5 сессий частота нежелательного поведения опустилась до стабильно нулевой. На третьем этапе вмешательства к третьей сессии частота стабилизировалась. На этапе обобщения за первые три сессии возникала только одна альтернативная реакция, что не может рассматриваться как нежелательное поведение. 


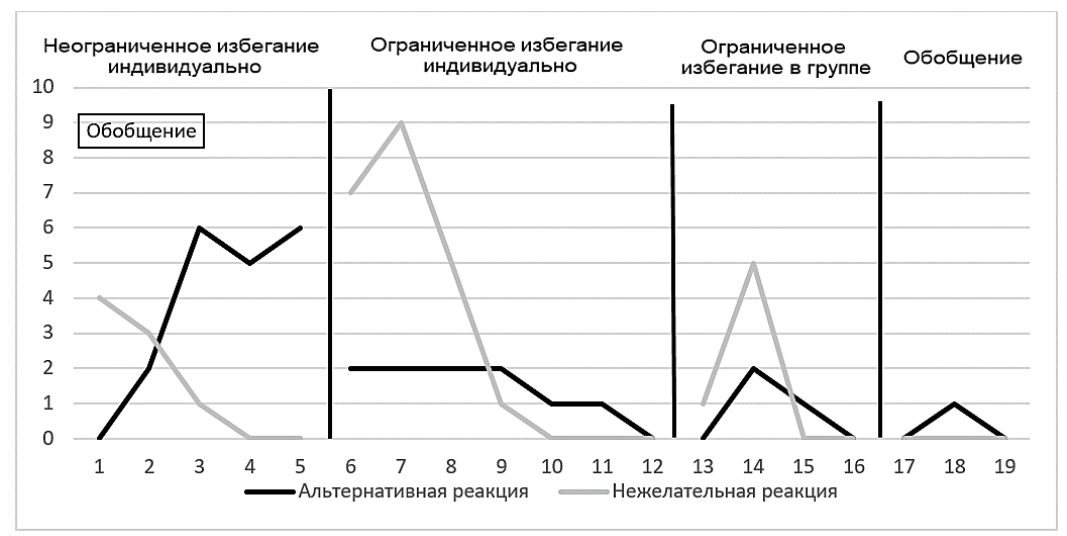

Рисунок 1. Динамика нежелательного поведения и альтернативного поведения за одну процедуру

Успешность процедуры демонстрирует нам, что метод дифференцированного подкрепления альтернативных реакций в частности и работа методами прикладного анализа поведения в целом могут применяться в коррекционной педагогике в качестве эффективного способа коррекции нежелательного поведения детей с эмоционально-волевыми расстройствами. При этом эффекты такой коррекции не ограничиваются повышением уровня социального функционирования самих детей с РАC, но также могут рассматриваться как мероприятие по созданию условий для эффективного наполнения социального опыта дошкольников, обучающихся в инклюзивных группах, в целом.

\section{Список литературы:}

1. Афонькина Ю.А., Кузьмичева Т.В., Рыжкова И.В. Бурцева А.В. Психологопедагогическое сопровождение инклюзивного образования: международный опыт, научный концепт и современная практика. Красноярск: ООО «Научноинновационный центр», 2015. $212 \mathrm{c}$.

2. Михайлова Л.А. Формирование социального опыта детей старшего дошкольного возраста в образовательном процессе детского сада // Вопросы дошкольной педагогики. 2015. № 3(3). С. 40-42. 


\title{
СЕКЦИЯ 2.
}

\section{ОБЩАЯ ПЕДАГОГИКА, ИСТОРИЯ ПЕДАГОГИКИ И ОБРАЗОВАНИЯ}

\section{ЭФФЕКТИВНЫЕ МЕТОДЫ И ПРИЕМЫ СОЗДАНИЯ ПРОБЛЕМНЫХ СИТУАЦИЙ НА УРОКАХ МАТЕМАТИКИ, ПРИ ОТКРЫТИИ НОВОГО ЗНАНИЯ В 5 КЛАССАХ}

\author{
Гришаева Светлана Алексеевна \\ учитель математики МАОУ СОШ № 1, \\ РФ, Кемеровская область, г. Мыски
}

Svetlana Grishaeva Insegnante di matematica MAOW Sosh n. 1, Russia, Myski

\begin{abstract}
АННОТАЦИЯ
В статье представлены основные идеи создания проблемных ситуаций на уроках математики, уроках открытия нового знания в 5 классе.

Автор делится своим видением данной технологии и опытом работы над созданием проблемных ситуаций на уроках математики в 5 классе. Предлагает наработки по постановке проблемных ситуаций на уроках открытия нового знания.

Цель данной работы: Применение проблемного обучения на уроках математики для формирования метапредметных и личностных результатов.

Задачи, которые необходимо решить для реализации данной цели:

1) продолжить изучать новаторские идеи для внедрения «проблемного обучения»;

2) определить роль и место проблемного обучения на уроках математики;

3) разработать ряд проблемных ситуаций на уроках математики и поделиться с коллегами.

\section{ABSTRACT}

The article presents the basic ideas for creating problem situations in mathematics lessons, lessons of discovering new knowledge in Class 5.
\end{abstract}


The author shares his vision of this technology and the experience of working on creating problem situations in mathematics lessons in Class 5. It offers developments in the creation of problem situations in the lessons of discovering new knowledge.

The purpose of this work: the application of problem learning in mathematics lessons for the formation of metapredmetnyh and personal achievements.

Tasks to be solved to achieve this goal:

1) continue to explore innovative ideas to implement " problem learning»;

2) determine the role and place of problem learning in mathematics lessons;

3) develop a number of problem situations in math lessons and share with colleagues.

Ключевые слова: проблемное обучение, проблема, УУД, метапредметные и личностные результаты.

Keywords: problem-based learning, problem-based learning, UUD, meta-subject and personal results.

Очень сложно стало обучать ребят, то им не очень интересно, то им скучно, то им трудно, то им.....Задача педагога сделать так, чтобы было интересно, доступно, легко. На помощь приходят разные методики преподавания предмета. Я, как учитель математики, взяла на вооружение проблемное обучение, которое помогает справиться с «не хочу, не могу, не умею, не получится». Китайская мудрость гласит: “Я слышу - я забываю, я вижу - я запоминаю, я делаю - я усваиваю”. Моя задача, как учителя, организовать учебную деятельность таким образом, чтобы полученные знания на уроке учащимися были результатом их собственных поисков. Но эти поиски необходимо организовать, при этом управлять учащимися, развивать их познавательную активность, т.е. учителю в этих условиях необходимо сделать учебный материал более доказательным и убедительным, формировать у обучающихся элементарные навыки поисковой и исследовательской деятельности, формировать и развивать положительное отношение, интерес, как к учебному предмету, так и к учению вообще. В связи с этим возникла необходимость использования в учебном процессе инновационных образовательных технологий развивающего типа: исследовательской (проблемно-поисковой), коммуникативной (дискуссионной), имитационного моделирования (игровой), психологической, деятельностной, рефлексивной и др. 
Одной из наиболее универсальных технологий, по моему мнению, применимых на разных ступенях образовательной системы и на любом предметном содержании, является технология проблемного обучения, которая заключается в том, чтобы предлагать ученикам для решения посильные задачи, которые вели бы их к собственным «открытиям». Проблемное обучение - это обучение, при котором учитель, создавая проблемные ситуации и организуя деятельность обучающихся по решению учебных проблем, обеспечивает оптимальное сочетание их самостоятельной поисковой деятельности с усвоением готовых законов математики. Сложность состоит в том, что нужно подобрать не очень легкие и не слишком сложные задачи, которые вели бы их к собственным «открытиям». Проблемное обучение - это обучение, при котором учитель, создавая проблемные ситуации и организуя деятельность обучающихся по решению учебных проблем, обеспечивает оптимальное сочетание их самостоятельной поисковой деятельности с усвоением готовых законов математики. Наиболее сложным этапом работы является постановка учебной проблемы, и в частности - создание проблемной ситуации. «Мышление начинается с проблемной ситуации» - слова Сергея Рубинштейна, выдающегося психолога и философа 20 века, как нельзя лучше раскрывают целесообразность использования технологии проблемно-диалогического обучения.

Учебная проблема существует в двух основных формах:

1) как тема урока;

2) как не совпадающий с темой урока вопрос, ответом на который является новое знание.

Следовательно, поставить учебную проблему, это значит помочь ученикам самим сформулировать либо тему урока, либо не сходный с темой вопрос для исследования.

Актуальность использования данной технологии обусловлена тем, что она построена на принципах развивающего обучения, она позволяет заменить урок объяснения нового материала уроком «открытия» знаний, учит учиться, что очень важно на современном этапе. 
Таблица 1.

\section{Пример 1. Этап постановки учебной проблемы на уроке математики в 5 классе по теме: «Проценты»}

\begin{tabular}{|c|c|}
\hline Деятельность учителя & Деятельность обучающихся \\
\hline $\begin{array}{l}\text { Предлагает учащимся задачу, дать } \\
\text { ответ на её вопрос, устно. } \\
\text { «Изменится ли цена товара, если } \\
\text { цену товара сначала повысили на } \\
10 \% \text {, а затем новую цену снизили } \\
\text { на 10\%.» }\end{array}$ & $\begin{array}{l}\text { Учащиеся предполагают, что цена товара } \\
\text { не изменилась (житейское представление) } \\
\text { (- }\end{array}$ \\
\hline $\begin{array}{l}\text { Дает задание: Решите задачу при } \\
\text { условии, что цена товара } 1000 \text { руб. }\end{array}$ & $\begin{array}{l}\text { Ребята решают и получают ответ, что } \\
\text { цена уменьшилась на } 10 \text { руб. }\end{array}$ \\
\hline $\begin{array}{l}\text { Задает вопросы: Итак, что вы } \\
\text { заметили? А как на самом деле? }\end{array}$ & $\begin{array}{l}\text { Отвечают: мы увидели, что цена товара не } \\
\text { осталась прежней!!!Она изменилась }\end{array}$ \\
\hline Учитель & Молодцы! \\
\hline $\begin{array}{l}\text { Спрашивает: «Значит, что мы } \\
\text { будем делать сегодня?» } \\
\text { Формулирует тему урока: } \\
\text { «Решение задач на проценты» }\end{array}$ & $\begin{array}{l}\text { Пытаются сформулировать цель } \\
\text { деятельности на уроке: «Правильно } \\
\text { решать задачи на «процент»»» } \\
\text { Правильно понимать процент. }\end{array}$ \\
\hline
\end{tabular}

В данном фрагменте присутствуют два приема: «яркое пятно» это удивление ребят неверностью предположения, «актуальность» это важность данной темы в повседневной жизни человека.

Таблица 2.

\section{Пример 2. Этап постановки учебной проблемы на уроке математики в 5 классе по теме: «Буквенные выражения»}

\begin{tabular}{|l|l|}
\hline \multicolumn{1}{|c|}{ Деятельность учителя } & \multicolumn{1}{c|}{ Деятельность обучающихся } \\
\hline Предлагает учащимся Найдите & Учащиеся считают четыре первых \\
значение выражения: & числовых выражений легко, а пятое \\
$(22+15)+(35+22)$ & выражение вызывает затруднения! Мы не \\
$(36+33)-(34-17)$ & можем посчитать последний пример, так \\
$36: 3+12 \cdot 2$ & как там не число, а буква \\
$12 * 11-10$ & \\
$387-300:$ х & \\
\hline $\begin{array}{l}\text { Значит не все выражения можно } \\
\text { вычислить? }\end{array}$ & Да, мы не можем вычислить выражение, \\
\hline $\begin{array}{l}\text { А как мы называем выражения 1-4, } \\
\text { а как назовем выражение 5??? }\end{array}$ & Числовые выражение. \\
\hline $\begin{array}{l}\text { Значит, сегодня мы будем работать } \\
\text { с какими выражениями? }\end{array}$ & С буквенными \\
\hline $\begin{array}{l}\text { И тема урока- ...... } \\
\text { Дают определение буквенного выра- } \\
\text { жения, находят сходство и различия }\end{array}$ & Ребята записывают тему урока- \\
\hline
\end{tabular}


В данном фрагменте присутствует анализ, сравнение, сталкивается знание с незнанием, решается проблема, которая возникает в ходе выполнения задания. Самостоятельно формулируется тему урока и определение буквенного выражения.

Таблица 3.

\section{Пример 3. Этап постановки учебной проблемы на уроке математики в 5 классе по теме: «Сравнение обыкновенных дробей с разными знаменателями»}

\begin{tabular}{|l|l|}
\hline \multicolumn{1}{|c|}{ Деятельность учителя } & \multicolumn{1}{|c|}{ Деятельность обучающихся } \\
\hline $\begin{array}{l}\text { Предлагает учащимся задачу, сравнить } \\
\text { дроби } 1 / 3 \text { и } 2 / 3 \\
12 / 18 \text { и } 3 / 18 ; 33 / 47 \text { и } 34 / 47 ; 12 / 13 \text { и } \\
22 / 26\end{array}$ & $\begin{array}{l}\text { Учащиеся легко сравнивают дроби с } \\
\text { одинаковыми знаменателями, } \\
\text { последнее задание вызывает } \\
\text { затруднение (- }\end{array}$ \\
\hline $\begin{array}{l}\text { Как мы сравниваем обыкновенные } \\
\text { дроби с одинаковыми числителями и } \\
\text { знаменателями? }\end{array}$ & Ребята проговаривают правило. \\
\hline $\begin{array}{l}\text { Чем отличается последнее задание от } \\
\text { предыдущих примеров? }\end{array}$ & $\begin{array}{l}\text { Отвечают: мы увидели, что } \\
\text { знаменатели разные }\end{array}$ \\
\hline $\begin{array}{l}\text { Учитель: и что мы будем делать? Как } \\
\text { сравнить? }\end{array}$ & $\begin{array}{l}\text { Дети высказывают свои } \\
\text { предположения }\end{array}$ \\
\hline $\begin{array}{l}\text { Так, значит, что мы сегодня будем } \\
\text { делать на уроке? }\end{array}$ & $\begin{array}{l}\text { Сравнивать дроби с разными } \\
\text { знаменателями! }\end{array}$ \\
\hline $\begin{array}{l}\text { Какие есть предложения? } \\
\text { Так какая тема урока? } \\
\text { Формулирует тему урока: «Сравнение } \\
\text { дробей с разными знаменателями», } \\
\text { формулируют алгоритм сравнения. }\end{array}$ & $\begin{array}{l}\text { Высказывают свои предложения. } \\
\text { (Привести дроби к одинаковым } \\
\text { числителю или знаменателю) } \\
\text { (Формулировка правила, открытие } \\
\text { нового знания) }\end{array}$ \\
\hline
\end{tabular}

Создание проблемной ситуации на уроке помогает сделать урок доступным, понятным и интересным. Урок перестанет быть скучным, а сам материал станет для ребенка доступным, так как ученик находит ответы на вопросы самостоятельно, открывая новые знания своими силами. Технология проблемного обучения обеспечивает следующие образовательные результаты: Регулятивные: умение решать проблемы. Коммуникативные: умение вести диалог. Познавательные: извлекать информацию, делать выводы. Личностные: в случае, если ставилась проблема нравственной оценки ситуации, гражданского выбора. Итак, урок, будет ли он любимым, доступным и понятным это может решить учитель, мечтающий творить, а не встречать ребят со словами: «Открыли тетрадь и записали тему урока». 


\title{
Список литературы:
}

1. Максимова В.Н. Проблемный подход к обучению в школе [Текст] /В.Н. Максимова // - Л., 1973. - 82 с.

2. Мельникова Е.Л. Технология проблемно-диалогического обучения [Текст] / Е.Л. Мельникова // Образовательная система «Школа 2100». Сборник программ .- М., 2009. - 400 c.

\section{ОПТИМАЛЬНЫЕ СПОСОБЫ ВЗАИМОДЕЙСТВИЯ И КОММУНИКАЦИИ В ПРОЦЕССЕ УЧЕБНО-ПЕДАГОГИЧЕСКОЙ ДЕЯТЕЛЬНОСТИ}

\author{
Лазарева Людмила Петровна \\ старший преподаватель, \\ Российский экономический университет \\ им Г.В. Плеханова, \\ РФ, г. Москва
}

\author{
OPTIMAL WAYS OF INTERACTION \\ AND COMMUNICATION IN THE PROCESS \\ OF EDUCATIONAL AND PEDAGAGICAL ACTIVITY
}

Lazareva Ludmila

Senior teacher, Plekhanov Russian University of Economics, Russia, Moscow

\begin{abstract}
АННОТАЦИЯ
В данной статье рассматриваются вопросы организации учебнопедагогического и воспитательного процесса, методы и приемы педагогического взаимодействия. Обозначены пути преодоления конфликтной ситуации. Определены условия для активизации мыслительной деятельности учащихся. Указаны задачи и требования к педагогу для успешной реализации учебно-педагогической деятельности.

ABSTRACT

This article discusses the organization of educational, pedagogical and educational process, methods and techniques of pedagogical interaction.
\end{abstract}


The ways of overcoming the conflict situation are outlined. The conditions for enhancing the mental activity of students have been determined. The tasks and requirements for the teacher for the successful implementation of educational and pedagogical activities are indicated.

Ключевые слова: активизация мыслительной деятельности, оптимизация процесса обучения, педагогический такт, принципы взаимодействия, стили общения.

Keywords: activation of the mental activity of students, optimization of the learning process, pedagogical tact, principles of interaction, communication styles.

Процесс социально-психологического общения - жизненная необходимость. Это достигается в процессе учебно-воспитательной работы.

Структура организации этого процесса довольно сложная. Она базируется на важных моментах:

\section{1. Умение выстроить алгоритм общения.}

Данный этап включает в себя процесс взаимодействия, результатом которого является общение. Формы общения могут быть разнообразными. Главенствующая роль, при этом, принадлежит межличностному общению. Насколько это общение будет результативным зависит от ряда факторов, таких как:

- умение слушать и слышать;

- умение контактировать с людьми различного уровня;

- умение четко изложить свою позицию и отстаивать ее до конца.

2. Выработать общую концепцию общения с последующей ее реализацией.

Чтобы выстроить правильную концепцию общения, нужно иметь четкое представление о предмете разговора, дискуссии, обсуждения. Немаловажную роль при этом играет личность собеседника. Чем интереснее собеседник, тем выше диапазон общения. В случае позитивного варианта общения достигается взаимопонимание. В случае негативного варианта - взаимодействие и общение, как таковые, полностью исключаются

\section{3. Определиться с контингентом обучающихся.}

Общение преподавателя с коллективом учащихся - неотъемлемая часть учебно-педагогического и воспитательного процесса. Чем выше уровень взаимодействия, тем качественнее общение. Межличностное общение сопряжено с активизацией мыслительной деятельности учащихся. Наиболее результативной формой общения является активное общение преподавателя с аудиторией и учащихся друг с другом. 
В общении с учащимися преподаватель передает им информацию, в общении между собой и преподавателем учащиеся усваивают ее.

Процесс общения, как говорит Карнеги, предполагает умение слушать и слышать. В данном случае задействованы все органы чувств: и зрение, и слух и другие различные рецепторы. Важную роль при этом играет тональность выражения, восприимчивость речи говорящего, умение интонировать и акцентировать внимание на существенных аспектах.

Положительный эффект от общения педагога с обучающимися достигается в случае полного взаимопонимания и обоюдной заинтересованности в общении. При отсутствии должного педагогического общения учащиеся, как правило, теряют интерес к предмету изучения, замыкаются в себе, боясь насмешек со стороны своих одноклассников или однокурсников. А это приводит к нежеланию общаться.

Задача педагога состоит в том, чтобы максимально раскрыть потенциальные возможности всего коллектива и индивидуальные способности каждого из обучающихся.

Актуальность данной проблемы отражена в работе советского педагога и психолога В.А. Канн-Калика «О педагогическом общении». Согласно его теории, структура профессионально-педагогического общения включает: [140]

1. Моделирование педагогом результативного общения с учащимися.

2. Организация процесса активной коммуникации (коммуникативная атака).

3. Управление общением в ходе педагогического процесса.

4. Анализ системы коммуникации для перспективного моделирования процесса общения.

Процесс моделирования сложный. Он предполагает высокую компетенцию педагога тщательно выстраивать учебно-педагогический процесс с целью его максимальной оптимизации. А дальше следует поэтапное решение поставленных задач. Реализация каждой из задач приближает педагога максимально к результативному общению с обучающимися.

В продолжение теории Канн-Калика, организация процесса активной коммуникации или так называемая «коммуникативная атака» сопряжена с активизацией мыслительной деятельности учащихся.

Этап управления общением в учебно-воспитательном процессе предполагает взаимодействие педагога с учащимися. Здесь возможно разнообразие форм. Одной из самых распространенных форм является ролевая игра, во время которой максимально раскрывается потенциал каждого участника. 
Учитель должен быть инициатором, лидером в управлении процессом общения. Для этого В.А. Канн-Калик советует обратить внимание на необходимость контакта с аудиторией, преодоления дистанционного барьера, который чаще всего имеет место на раннем этапе педагогической карьеры. Что в этом случае целесообразно сделать?

- Четко обозначить цель для успешного взаимодействия с аудиторией.

- Использовать все общедоступные средства коммуникации для достижения поставленной цели.

Важную роль в процессе коммуникации играет тесный контакт педагога с аудиторией. Как показывают проведенные исследования, у педагога с положительным психоэмоциональным зарядом и позитивным отношением к обучающемуся аудитория раскована, общительна, открыта к общению. Негативное отношение к аудитории, неустойчивость позиции учителя, подпадающего под власть своих отрицательных эмоций, создает атмосферу недоверия, что приводит, в конечном итоге, к возникновению конфликтной ситуации.

Задача педагога, по утверждению ученого, в скорейшем разрешении возникшего конфликта, а лучше - в его предотвращении. Для погашения конфликтной ситуации должны быть задействованы всевозможные инструменты, облегчающие процесс педагогического общения.

Канн-Калик выделяет несколько видов педагогического общения, а именно: [141]

общение на основе дружеского расположения,

общение - дистанция,

общение - устрашение,

общение - заигрывание

Что касается меня, я бы к этим стилям общения добавила общение на основе высоких профессиональных установок педагога.

Такой педагог пользуется большим авторитетом у обучающихся. Он является образцом для подражания. Его доброжелательное и уважительное отношение к аудитории вызывает положительные эмоции, чувство удовлетворенности и даже восхищение.

Стиль педагогического общения на основе дружеского расположения тесно связан с первым. Педагог в данном случае выполняет роль наставника, старшего товарища, руководителя, находящегося в постоянном поиске методов и приемов для успешного взаимодействия с аудиторией. Данный стиль предполагает увлеченность общим делом при отсутствии панибратства.

К сожалению, довольно распространенным стал стиль общение дистанция. Новые времена диктуют новые формы общения. К этому 
вынуждают объективные обстоятельства. Сегодня как никогда дистанционное обучение в условиях пандемии стало наиболее востребованной формой общения. Эта форма общения, по словам Канн-Калика, снижает общий творческий потенциал совместной работы с учащимися. И я с этим утверждением полностью согласна. Моя практика работы в университете показала, что дистанционная работа не позволяет должным образом контролировать уровень знаний студентов.

Крайней формой общения является общение - устрашение. Такой стиль общения соединяет в себе отрицательное отношение к учащимся и авторитарность в способах организации деятельности, создает обычно на уроке атмосферу нервозности, эмоционального неблагополучия, тормозит творческую деятельность, так как ориентирует не на программу действий, а на ее ограничения и запреты.

Общение - заигрывание характерно для молодых преподавателей, стремящихся любыми способами завоевать авторитет, а это приводит к обратному результату - нежеланию общаться.

Педагог не имеет права ни на миг забывать о своей роли в учебнопедагогическом и воспитательном процессе. В данном контексте актуальны слова Н.К. Крупской: «То, что говорит любимый учитель, воспринимается совсем по-другому, чем то, что говорит презираемый ими, чуждый им человек. Самые высокие идеи в его устах становятся ненавистными» [142].

\section{Социально - психологический портрет руководителя}

В психологии разработаны довольно четкие параметры взаимодействия педагогического общения. В этом плане представляет интерес книга А.Н. Лутошкина «Как вести за собой», в которой он выделяет три стиля руководства и дает им образные названия: [143]

- авторитарный стиль («разящие стрелы»);

- демократический стиль («возвращающийся бумеранг»);

- либеральный стиль («плывущий плот»)

Авторитарный стиль («разящие стрелы»)

Педагог единолично определяет нормы и формы работы группы, подавляя тем самым какую-либо инициативу участников процесса общения. Основные формы взаимодействия - приказ, указания, инструкции к обязательному исполнению распоряжений.

Демократический стиль («возвращающийся бумеранг»)

Этот стиль руководства предполагает опору руководителя на коллектив в целом, и индивида - в частности. Он основан на взаимном доверии и уважении. Своей основной задачей учитель считает хорошую организацию учебно-педагогического и воспитательного процесса, 
направленного на активизацию мыслительной деятельности учащихся. Используя различные методы и приемы, он стремится пробудить интерес учащегося к изучаемому предмету. Если этого удастся добиться, то диапазон общения педагога с обучающимися значительно расширятся.

Либеральный стиль «плывущий плот»)

Анархический, попустительский на раннем этапе общения. Учитель старается не вмешиваться в жизнь коллектива, фактически отстраняясь от взаимодействия с аудиторией. Об авторитете педагога в данном случае не может быть и речи.

Возвращаясь к упомянутому выше авторитарному стилю руководства, следует добавить, что данный стиль создает крайне негативную обстановку в коллективе, где подавляется инициатива, мыслительная деятельность учащихся. Ни о каком взаимодействии, а тем более о взаимопонимании не может быть и речи.

\section{Педагогический такт}

Тактичность - это непременное качество педагога, неотъемлемая часть его педагогического мастерства.

Педагогический такт заключается в уважительном отношении ко всей аудитории в целом и индивиду - в частности.

Доверие к учителю - залог успешной коммуникации педагога с учащимися. Отсутствие его - верный путь к недопониманию, вплоть до возникновения конфликтной ситуации.

Анализ возникновения конфликтной ситуации в коллективе, как показывает практика, возникает на почве неуважительного отношения педагога к учащемуся во всех его проявлениях, начиная с внешнего вида учащегося, его способностью воспринимать и воспроизводить предлагаемый учебный материал к изучению.

Оценка и контроль результативности работы учащихся должны быть объективными. Ученик, как правило, раскрывается, если он чувствует одобрительное и участливое отношение со стороны педагога. Большое значение в формировании правильного стиля общения имеют также такие аспекты, как чувство справедливости и объективности. При этом немаловажную роль играет изучение опыта работы своих коллег, постоянный поиск и совершенствование педагогического мастерства. Одной из важных форм общения является убеждение. Формами убеждения могут быть диспуты, дискуссии, беседы, круглые столы и т.д. Инициатива при этом может исходить как от учителя, так и от ученика. Чтобы убеждение, как метод взаимодействия, было максимально действенным, необходимо учитывать возрастные и индивидуальные особенности личности. Убеждение может быть конструктивным лишь в том случае, 
если педагог уверен в правоте своей идеи. Для этого он должен обладать большим арсеналом знаний и умением аргументированно донести до собеседника необходимость реализации поставленной задачи.

Наряду с убеждением, как методом педагогического взаимодействия, определенная роль в педагогическом процессе принадлежит внушению. Внушение - одно из средств взаимодействия людей в процессе совместной деятельности.

Долгое время роль внушения в педагогическом процессе не признавалась. Однако, хотим мы этого или нет, элемент внушения присутствует в педагогической практике, является частью педагогического взаимодействия. Правильно организованное внушение опосредованно стимулирует сознательную активность обучающихся, а различные его виды обогащают арсенал средств педагогического взаимодействия. Благодаря этому возможно наиболее тонко и тактично осуществлять индивидуальный подход к каждому из обучающихся. Учитель не должен игнорировать вышеупомянутый метод, ибо он влияет на психоэмоциональное состояние учащихся. А в случае его успешного применения возможно решить ряд многоплановых задач, связанных с обучением, воспитанием, приобщением к интересному делу и т.д.

Обращаясь к внушению, как методу педагогического воздействия, каждый учитель должен четко определить, а есть ли у него достаточный арсенал средств и знаний для реализации поставленных задач.

Не владея вышеперечисленными способами воздействия на ученика, невозможно добиться взаимодействия и взаимопонимания в общении.

Изучение опыта работы молодых специалистов показало, что они владеют лишь небольшим арсеналом выразительных средств, а именно: отсутствие должной мимики и жестов, монотонность ведения урока, отсутствие эмоциональной составляющей. Все это замедляет процесс усвоения, а порой парализует полностью, либо частично процесс активизации мыслительной деятельности. Основным средством влияния на индивидум как при убеждении, так и внушении является слово. Слово, произнесенное без эмоциональной окраски малоэффективно и, как правило, не способствует убеждению. По утверждению великого русского писателя Л.Н. Толстого: «Слово - выражение мысли. И потому слово должно соответствовать тому, что оно выражает». Об этом должен всегда помнить учитель и постоянно находиться в творческом поиске.

\section{Список литературы:}

1. Канн-Калик В.А. Учителю о педагогическом общении: Кн. для учителя М., Просвещение, 1987. 
2. Канн-Калик В.А. Основы профессионально - педагогического общения. Грозный, 1979.

3. Крупская Н.К. О требованиях к учителю. М., Просвещение. 1989.

4. Лутошкин А.Н. Как вести за собой. М., Просвещение. 1986.

5. Основы педагогического мастерства: Учеб. пособие для пед. спец. Высших учебных заведений под ред. И.А. Зязюн. Мастерство педагогического взаимодействия. М.: Просвещение, 1989, с. 136 - 152. 


\title{
СЕКЦИЯ 3.
}

\section{ТЕОРИЯ И МЕТОДИКА ОБУЧЕНИЯ И ВОСПИТАНИЯ}

DOI: $10.32743 / 25419862.2021 .3 .45 .257953$

\section{ОПЫТ РАБОТЫ ПО ФОРМИРОВАНИЮ ОСНОВ ГРАЖДАНСТВЕННОСТИ У ДЕТЕЙ СТАРШЕГО ДОШКОЛЬНОГО ВОЗРАСТА}

\author{
Александрова Илона Викторовна \\ канд. пед. наук, \\ доч. кафедры педагогики и психологии детства \\ Петрозаводского государственного университета, \\ РФ, г. Петрозаводск
}

\begin{abstract}
АННОТАЦИЯ
В статье раскрывается и предлагается возможный путь решения проблемы гражданского воспитания детей старшего дошкольного возраста. Предлагается комплекс мероприятий, построенный с учетом требований комплексно-тематического планирования, используемый в работе дошкольных образовательных организаций.
\end{abstract}

\section{ABSTRACT}

The article reveals and suggests a possible way to solve the problem of civic education of older preschool children. A set of measures is proposed, built taking into account the requirements of complex thematic planning, used in the work of preschool educational organizations.

Ключевые слова: дети дошкольного возраста, нравственное воспитание, гражданское воспитание, комплексно-тематическое планирование.

Keywords: preschool children, moral education, civic education, complex thematic planning.

Проблема гражданского воспитания подрастающего поколения сегодня одна из наиболее актуальных. В 2001 году принята государственная программа "Гражданско-патриотического воспитание детей дошкольного возраста. В связи с этим заметно активизировалась 
работа исследователей и дошкольных образовательных учреждений, одна за другой стали проводиться научно-практические конференции по вопросам гражданского воспитания детей.

Следует отметить, что раньше не уделялось должного внимания проблеме гражданского воспитания дошкольников: недостаточно исследований в данной области, в детских садах не считалось нужным проводить работу по гражданскому воспитанию. [1,82]

Но в последние десятилетия в нашем обществе значительно изменилось отношение к таким ценностям, как патриотизм, долг, честь, достоинство, знание героического прошлого своего государства.

От эффективности организации гражданского воспитания во многом зависит политическая, экономическая и социальная состоятельность нашего общества в будущем.

В процессе гражданского воспитания формируются качества личности, «характеризующие её способность к активному проявлению своей гражданской позиции через социально значимую, практико-ориентируемую деятельность» (М.Ю. Новицкая).

Целью нашей работы стала разработка комплекса мероприятий по гражданскому воспитанию детей старшего дошкольного возраста, опираясь на принцип тематического планирования материала (по блокам), иерархичности (от простого к сложному), личностно-ориентированного общения, наглядности, занимательности, а также с учётом ведущего вида деятельности детей дошкольного возраста - игра. Также использовать занятия различной направленности (познавательное развитие, экология, рисование, Исходя из цели, были поставлены следующие задачи:

1. Формировать положительное отношение и чувство сопричастности к родному дому, семье детскому саду, городу, природе родного края,

2. Познакомить детей с государственной символикой: флаг, герб, гимн, язык.

3. Познакомить с природой России, воспитание любви и чувства прекрасного.

4. Познакомить с картой мира, с глобусом (учить находить и показывать Россию)

5. Воспитывать у детей положительное отношение и чувство симпатии по всем расам и народам. Воспитание любви и уважения к своей Родине - России, к своей нации, государственной символике, традициям государства, общественным праздникам.

На основании изучения современной литературы по гражданскому воспитанию детей старшего дошкольного возраста, пособий по 
реализации государственной программы «Гражданско-патриотическое воспитание дошкольников», нами был разработан собственный комплекс мероприятий по гражданскому воспитанию,

На наш взгляд, тематическое планирование способствует эффективному усвоению детьми знаний о своей стране, родном крае, помогает им устанавливать взаимосвязь между событиями и явлениями. Все предлагаемые темы связаны между собой логически и вместе представляют целостную картину сведений о России.

Комплекс мероприятий по гражданскому воспитанию детей старшего дошкольного возраста «Мы живём в России»

Разработанный комплекс мероприятий включает в себя четыре взаимосвязанных между собой блока (каждый блок включает в себя организованную образовательную деятельность различной направленности: познавательное развитие, экология, рисование, беседа, дидактические игры).

Первый и второй блоки включают в себя по пять занятий, третий блок включает четыре занятия, а также для закрепления материала используются дидактические игры, четвертый блок включает в себя восемь занятий и дидактические игры для закрепления изученного материала. Таким образом, данный комплекс мероприятий по всем блокам в целом включает в себя 22 занятия.

\section{Блок №1. «Мир людей»}

Данный блок реализуется по средством следующих задач:

Способствовать формированию, расширению понятия о том, что в любом сообществе людей (детский сад, семья и др.) действуют разные правила, которые выполняют все члены этого сообщества. Воспитывать любовь к родному дому, семье, детскому саду.

- Я и моя семья. Занятие познавательному развитию.

- Мой дом детский сад - моя маленькая Родина. Занятие познавательному развитию.

- Что такое дружба? Занятие познавательному развитию.

- Чтение сказок «Кот, петух и лиса», «Три медведя» и др. (для закрепления понятия семья).

- «Кто в круге?» Моделирование отночений между людьми при помощи «кругов Эйлера».

\section{Блок №2 «Родной город»}

Данный блок реализуется посредством следующих задач: 
Формировать, расширять, закреплять представления детей об основных достопримечательностях, городских зданиях, улицах. Воспитывается гордость за свою малую Родину.

- Мой город, в котором я живу.

- Улицы родного города. Занятие по познавательному развитию, рисованию.

- Достопримечательности нашего города. Занятие по познавательному развитию, рисованию.

- Рассматривание иллюстраиий достопримечательностей родного города, картин карельской природы, чтение карельских сказок, рассматривание иллюстраций к карельским сказкам Т. Юфа. Занятие по рисованию «Нарисуй понравившуюся сказку».

\section{Блок №3 «Родная природа»}

Данный блок реализуется посредством следующих задач:

Любовь к родной природе - одно из проявлений гражданственности. Дети получают представление о природе родного края, реках, озёрах, растениях, животном мире. Воспитывается умение эстетически воспринимать красоту окружающего мира, относиться к природе бережно, эмоционально, желание больше узнать о родной природе.

- Человек природе - друг. Занятие по экологии.

- Русский лес-чудесный лес. Занятие по экологии, рисованию.

- Животные и растения нашей страны. Занятие по экологии.

- Для закрепления изучаемого материала используются дидактические игры:

1. «С какого дерева листок». Закрепление названий деревьев русского леса.

2. «У кого какой домик». Закрепление знаний детей о жилищах диких животных, птии, насекомых.

3. «Чьи припасы». Закрепление знаний детей о том, чем питаются дикие животные.

4. «Что в лесу растёт, кто в лесу живёт». Закрепление знаний детей о растительном и животном мире русского леса.

\section{Блок №4 «Родная страна»}

Данный блок реализуется посредством следующих задач:

1. Представления о символике: герб, гимн, флаг, представление о значении гос. символов. Воспитывать уважительное отношение к символам, знакомство со столицей. 
2. Формируются представления о том, что Россия - многонациональная страна, формируется основы гражданско-патриотических чувств: любовь и уважение к своей стране, её культуре, осознание личной причастности к жизни России.

3. Дать понятие о правах человека, правах ребёнка. Формировать представления детей об условиях обеспечивающих сохранение и укрепление здоровья каждого ребёнка, дать понятие «право на безопасные условия жизни», «право не подвергаться жестокому обращению», научить детей разбираться в таких понятиях как гуманности, доброжелательности, терпимость, а также определять жестокое обращение и уметь находить защиту от него.

4. Воспитание толерантного отношения к представителям других национальностей, расширять представления об окружающем мире и разных странах, развивать логическое мышление.

- Нама страна Россия.

- Главньй город нашей странь - Москва

- Три иввета Российского флага.

- Государственные символы России - герб.

- Цвета в гербах животные в Гебах. Беседа.

- Что значит быть гражданином? Права и обязанности гражданина России.

- Я имею право.

- Разноцветные люди, дети разных национальностей.

- Для закрепления изучаемого материала используются дидактические игры:

1. «Кто в какой стране живёт». Закрепления названий стран, населения стран.

2. «Узнай наш флаг (герб)». Закреплять знания детей о государственном флаге, гербе, учить узнавать (называть) наш флаг и герб среди флагов и гербов других стран.

3. «Иностранеи». В игровой форме закрепить знания детей о Родной стране (о столище), о родном городе.

Таким образом, воспитание гражданственности у детей дошкольного возраста - это многогранный и трудоёмкий процесс, который затрагивает все стороны жизнедеятельности. Участие в этом процессе должны принимать и семья, и образовательные учреждения. Только общими усилиями можно воспитать поколение людей, которые станут полноценными гражданами своей страны. Работа по формированию основ гражданственности у детей старшего дошкольного возраста должна носить комплексный характер, пронизывать все виды деятельности 
дошкольника, осуществляться в повседневной жизни и в процессе организованной образовательной деятельности.

\title{
Список литературы:
}

1. Комратова Н.Г. С чего начинается Родина. Дошкольное воспитание №6., 2003. c. 82.

2. Новицкая М.Ю. Наследие. Гражданское воспитание в детском саду. М.: Педагогика, 2004.

\section{МАЛЫЕ ЖАНРЫ ФОЛЬКЛОРА КАК ИНСТРУМЕНТ ФОРМИРОВАНИЯ КОММУНИКАТИВНОЙ КОМПЕТЕНЦИИ ПРИ ИЗУЧЕНИИ РКИ}

\author{
Астафурова Маргарита Владимировна \\ студент (магистратура), \\ направление «Русский язык как иностранный: \\ теория и актуальные методики эффективного обучения», \\ Институт филологии, журналистики и межкультурной \\ коммуникации ЮФУ, \\ РФ, г. Ростов-на-Дону
}

Коммуникативная компетенции есть способность решать средствами изучаемого языка актуальные для личности и социума задачи общения в личной сфере, общественной, профессиональной, образовательной.

«Основная задача преподавания иностранных языков в России в настоящее время - это обучение языку как реальному и полноценному средству общения», - считает С.Г. Тер-Минасова [3]. Коммуникативная компетенция - это интегративное образование, включающее в себя лингвистический, социолингвистический и прагматический аспекты. В процессе обучения РКИ определение понятия коммуникативной компетенции приобретает особое значение и соотносится с уровнем владения русским языком. Для успешного овладения каждым языковым уровнем иностранным студентам необходимо в одинаковой степени владеть коммуникативной компетенцией в разных видах речевой деятельности.

Как утверждает С.Г. Тер-Минасова, «для того, чтобы научить иностранному языку как средству общения, нужно создавать обстановку реального общения, наладить связь иностранных языков с жизнью, 
активно использовать иностранные языки в живых, естественных ситуациях» [3].

При изучении языка формируется коммуникативная компетенция, то есть умения, прежде всего, общаться, устанавливать как деловые, так и дружеские контакты с людьми.

Одна из важных задач при изучении языка - это показ его особенностей, обратить внимание на красоту русского языка и его богатство возможно через устное народное творчество: пословицы, загадки, сказки, песни. Важным условием при обучении языку является аутентичность текстов, а фольклор и является таковым. Аутентичные тексты должны отвечать определенным требованиям, к таким требованиям относятся: использование аутентичной лексики, фразеологии и грамматики, связность текста, адекватность используемых языковых средств в предлагаемой ситуации, отражение особенностей культуры и национальной ментальности носителей языка, информативная и эмоциональная насыщенность.

Изучение русского языка на материале малых жанров, пословиц, поговорок, дает возможность лучше понять средства выражения изучаемого языка, характер мышления народа, его национальное своеобразие. Народ и язык - понятия неразделимые, в языке закрепляется опыт народа.

Будучи квинтэссенцией народной мудрости, пословицы и поговорки представляют собой материал для изучения культурных эталонов, символов и стереотипов русского народа, расширяя представление иностранцев о русской культуре, русских традициях и ценностях. Представляя собой микротекст, они могут быть востребованы в качестве материала для работы в иностранной аудитории: их можно использовать для развития различных навыков и умений, а также в качестве средства постижения специфики русской культуры, снятия языкового барьера и улучшения межкультурной коммуникации. Это небольшие мудрые изречения, в которые вложена и народная педагогика, и опыт поколений, и оценка как человеку, так и его поступкам, действиям.

Т.А. Пищулина уверена, что пословицы «могут служить хорошим средством формирования социокультурной компетенции» [2], так как дают представление об особенностях русской культуры. Через пословицы обучаемые могут пополнить словарный запас, свои знания о стране, понять культуру народа и особенности русского национального характера. Пословицы могут создавать особенную атмосферу на занятии, так как развивают творческое мышление, помогают уловить черты характера человека (Говорит красно, да слушать тошно. Не тебе бы говорить, да не мне бы слушать. Сам не дерусь, а семерых не боюсь), сопоставить отношения между людьми (Друзей - то много, да друга нет. Не искал бы в селе, а искал бы в себе). 
Пословицы краткие, но яркие выражения выполняют определённые функции:

1. Уточняют полученную информацию.

2. Усиливают высказывание и делают его ярче, образнее.

3. Могут подвести итог при обсуждении темы или проблемы.

Использовать пословицы можно на разных этапах изучения языка: главное при отборе учитывать уровень владения русским языком. Важно подобрать такие, где можно отрабатывать опознание звуков или отработку техники чтения. (Терпение и труд-всё перетрут. Семь бед - один ответ (д|т), Маленькое дело лучше большого безделья. Любишь кататься, люби саночки возить. Худо тому, кто добра не делает никому). Используя пословицы, можно выработать целую систему упражнений, с помощью которых формируется не только развитие фонетических навыков, но и речевых, и коммуникативных, где нужно идти от простого к сложному, переходить от отработки отдельных навыков к практике, подчёркивая при этом мудрость, вложенную в эти мини-тексты, национальную культуру народа, которая формировалась веками. Пословица - это минипьеса. Упражнения и их задания определяются целью и характером действия обучаемых. Использование пословиц и поговорок на уроках РКИ - это возможность формировать целый ряд компетенций, но всегда надо иметь в виду уместность их использования. Весь подобранный материал можно разделить на тематические группы: «Погода», «Семья», «Труд», «Дом», «Дружба», «Человек». По мнению К.А. Деменевой, отбор пословиц и поговорок должен быть очень строгим и учитывать следующие параметры:

- частотность, употребимость в современном языке;

- грамматическая валентность (способность к трансформации в предложениях);

- стилистическая валентность (способность встраиваться в высказывания разных стилей и жанров);

- универсальность контекстов употребления, их повсеместная встречаемость и узнаваемость;

- образность и эмоциональность;

- лексико-грамматическая прозрачность (интуитивная понятность отдельных элементов) [1]. В связи с этим предлагается ранжировать данный материал по уровням владения языком и распределять его равномерно с тем, чтобы на уроках регулярно появлялась новая пословица или поговорка. Такой дидактический материал - это удобный инструмент, который поможет решить ряд методических задач и даст положительный результат в формировании многих составляющих коммуникативной компетенции. 
Фольклорные тексты представляют собой богатый дидактический материал для культурологической, лингвострановедческой и лексической работы. Они позволят обучающимся пополнить запас разговорнобытовой лексики, познакомиться с простыми народными выражениями, традициями, то есть изучение русского языка как иностранного должно быть не только прагматичным, но и духовным. Ещё К.Д. Ушинский писал, что очень важно учить не просто говорить, а видеть богатство культуры страны изучаемого языка.

Устное народное творчество, зародившееся в далёком прошлом, это источник национальной культуры, языка. Фольклорные произведения отличает не только идейная глубина, но и высокое художественное качество. Поэтика богата системой изобразительных средств. Народное творчество наглядно показало, как зарождался и развивался русский язык. Хотя язык произведений устного народного творчества специфический, но именно в нём шло формирование русского языка как национального. Этот язык выполняет, прежде всего, коммуникативную функцию. Язык фольклора - это народный язык, он выражает содержание фольклорных текстов.

\section{Список литературы:}

1. Деменёва К.А. Пословицы и поговорки на уроках РКИ. Журнал «Русский язык за рубежом» №6 2013.

2. Пищулина Т.А. Пословицы и поговорки как средства формирования социокультурной компетенции. Минск6 БГУ, 2013.

3. Тер-Минасова С.Г.Язык и межкультурная коммуникация. Москва «Слово» 2000/.

4. Ушинский К.Д. Педагогические сочинения 6т. Составитель С.Ф. Егоров М., Педагогика, 1998.

DOI: $10.32743 / 25419862.2021 .3 .45 .255251$

\section{КОМПОЗИЦИЯ ПЕДАГОГИЧЕСКОГО ИЗМЕРЕНИЯ ДЛЯ УРОКОВ АНГЛИЙСКОГО ЯЗЫКА}

Буслаева Тамила Хабировна

аспирант,

Казанский (Приволжский) федеральньй университет, $P \Phi$, г. Казань 


\title{
PEDAGOGICAL MEASURING IN ENGLISH LESSONS
}

\author{
Tamila Buslaeva \\ Postgraduate student, \\ Kazan (Volga Region) Federal University, \\ Russia, Kazan \\ Julia Maksimova \\ Postgraduate student, \\ Kazan (Volga Region) Federal University, \\ Russia, Kazan
}

\begin{abstract}
АННОТАЦИЯ
Тестирование стало неотьемлемой частью педагогической деятельности. Понимание принципов построения тестов для проверки знаний учащихся крайне необходимо в повышении качества обучения. Данная статья отражает базовые правила составления вопросов и вариантов ответа для разных типов тестов. В качестве основы для данного исследования были взяты примеры тестовых заданий по предмету Английский язык.

Testing has become an integral part of teaching activities. Understanding the principles of building tests to examine students' knowledge is essential in improving the quality of learning. This article reflects the basic rules for composing questions and answer options for different types of tests. Examples of test tasks on the English language subject were taken as a basis for this study.
\end{abstract}

Ключевые слова: тест, тестирование, педагогическое измерение, английский язык, иностранный язык, требования к тесту, виды тестов.

Keywords: test, testing, pedagogical measurement, the English language, foreign language, test requirements, types of tests. 
В современном российском обществе на данный момент не существует консенсуса в вопросе целесообразности и эффективности использования тестирования в образовании. Тем не менее, тестовый контроль получает все большее распространение на занятиях в школе и вузе. С помощью него педагоги легко могут провести диагностику образовательного процесса, проверить, оценить знания учащихся, накопить и проанализировать статистические данные, выявить динамику, тенденции и спрогнозировать дидактически процесс [3, с. 161].

Педагоги в ежедневной работе с учащимися предпочитают применять тестовый контроль, потому что с его помощью можно быстро проверить уровень знаний большого количества учащихся. Объективность оценки результата крайне высока. Но нельзя считать каждый контроль с вариантом ответов, как качественный и правильно составленный тест.

Задачей данного исследования мы ставим определить критерии качественного педагогического теста, правил его создания.

В первую очередь необходимо определить понятие «тест». По Аванесову В.С. педагогический тест - это «система знаний возрастающей трудности, специфической формы, позволяющая качественно и эффективно измерить уровень и оценить структуру подготовленности учащихся» $[1$, с. 7$]$.

При всем многообразии видов тестов можно определить два основных: традиционный и нетрадиционный.

В традиционных тестах испытуемые проходят контроль в идентичных условиях, абсолютно совпадает содержание задания, выделенное на решение время и шкала оценок результатов тестирования.

Традиционные тесты бывают гомогенными и гетерогенными. Первые являются самыми популярными, так как они формируются для проверки знаний по одной, конкретной учебной дисциплине. Вторые, используются для комплексной, объективной оценки по нескольким учебным дисциплинам. К примеру, такие тесты проходят выпускники школ, абитуриенты, кандидаты на должность при приёме на работу.

Нетрадиционные тесты подразделяются на интегративные и адаптивные.

Интегративные тесты нацелены на выявление знаний учащихся в двух и более дисциплинах, правильные ответы на задания можно найти только при понимании межпредметных связей. Такой вид тестирования чаще всего проводится в высших учебных заведениях, при накоплении большого объема знаний в различных областях.

Адаптивные тесты появились из-за необходимости протестировать учащихся с разным уровнем подготовки. Нет надобности давать простые 
задания успевающему студенту. Это будет только расхолаживать его, время будет потрачено впустую без какой-либо образовательной значимости. Так же как и неприемлемо предлагать решить сложное задание отстающему студенту. Результатом может стать утрата веры в свою способность усвоить материал, полная демотивация. Данный вид тестового контроля осуществляется при помощи компьютеров. При каждом правильном ответе следующее задание будет повышенной сложности. Если же учащийся отвечает неверно, компьютерный алгоритм следующим заданием предложит более простой вопрос.

В спецификации консорциума IMS QTI (Question and Test Interoperability - унифицированные вопросы и тесты) существует более 20 форм тестов, все они могут быть сведены к повсеместно известным открытым и закрытым формам заданий.

Открытые вопросы требуют от учащегося самостоятельного ответа (задание на дополнение, эссе, выполнение расчета и т.д.), закрытые вопросы уже имеют готовые ответы (задания с выбором из множества ответов, нескольких правильных ответов, установление правильной последовательности, соответствия и т.д.).

В процессе композиции тестовых заданий педагог должен учитывать требования, предъявляемые к качественному тесту, и неукоснительно следовать им.

1. Тестовое задание должно быть сформулировано четко, понятно для читателя. Оно должно восприниматься однозначно, без переносного значения.

2. Формулировка задания должна быть лаконичной, без использования сложноподчиненных предложений, лишних вводных слов. Все, что не несет смысловой нагрузки должно быть удалено из вопроса. В среднем в вопросе должно быть от 5 до 9 слов, но чем меньше, тем лучше [1, с. 34].

3. Каждый вопрос должен спрашивать о чем-то одном. Утяжеление вопроса заданиями что-то найти, решить и объяснить не имеет смысла. Необходимо делить такие задания на несколько вопросов.

4. В тесте необходимо конкретно определить, что считается правильным ответом. Не допускается определение понятия через перечисление элементов, не входящих в него. В примере ниже мы можем видеть, что тестовое задание открытой формы содержит огромное количество возможных ответов.

Английские согласные по признаку палатализачии не

5. В соответствии с законом исключенного третьего классической логики нельзя употреблять такие варианты ответов, как «все ответы верны», «все ответы неправильные», «правильного ответа нет». 
6. Для каждого ответа необходимо обеспечить место в задании. Например, в вопросах открытой формы ответ должен быть вписан вместо прочерка, следуемый после текста задания. Если же это вопрос с выбором, то студент должен выбрать соответствующую букву или цифру.

7. Необходимо обеспечить место для подбора ответа в самом задании. Пример ниже требует прочерка в начале вопроса.

She (to help) mother yesterday?a) did ... help b) did ... helped c) does ... help $\mathrm{d}$ ) is ... helping

8. Необходим тщательный подбор дистракторов, которые призваны отвлечь внимание неподготовленного учащегося от правильного ответа.

9. Ответы на выбор не должны иметь явно неподходящий вариант. Как в примере, где вариант D будет отметен даже самым слабо подготовленным студентом.

You'll be here tomorrow, ...?

a) isn't it b) won't you c) will you d) to run

10. Избегать вопросов на выражение мнения, таких как «Что является самым важным...?». Степень важности определяется индивидуально у отдельных учащихся.

Для таких важных событий, как Единый государственный экзамен эксперты тщательно продумывают тестовые задания, вычисляют их сложность, расположение вопросов, внимательно подбирают ответы на выбор и многое другое. Таким же тщательным образом педагоги различных дисциплин должны создавать тесты для электронных образовательных ресурсов в высших учебных заведениях и тесты начального, промежуточного и итогового контролей. Вышеизложенные требования смогут стать ориентиром для преподавателя в самооценке качества тестирования.

\section{Список литературы:}

1. Аванесов В.С. Теория и методика педагогических измерений (Материалы публикаций в открытых источниках и Интернет) Подготовлено ЦТ и МКО УГТУ-УПИ, 2005 г. - 98 с.

2. Кабанова Т.А. Тестирование в современном образовании / Кабанова Т.А., Новиков В.А. - М.: Высшая школа, 2010. - 381 с.

3. Егоров В.В. Педагогика высшей школы: Учебное пособие / Егоров, В.В., Скибицкий Э.Г., Храпченков В.Г.. - Новосибирск: САФБД, 2008. - 260 с. 


\title{
КОНЦЕПЦИИ, МЕТОДЫ И СПЕЦИФИКА ПЕДАГОГИКИ В МУЗЫКАЛЬНОЙ ШКОЛЕ
}

\author{
Гильманова Гузель Забировна \\ преподаватель \\ Детской Школь Искусств им. Салиха Сайдашева, \\ РФ, Республика Татарстан, с. Высокая Гора
}

\section{EXAMINATION OF DRAFT REGULATORY LEGAL ACTS}

\section{Guzel Gilmanova}

Teacher of the Children's School of Arts.Salikha Saidasheva, Russia, Republic of Tatarstan, Vysokaya Gora village

\begin{abstract}
АННОТАЦИЯ
Цель статьи рассмотреть современные достижения в области музыкально-педагогических исследований, образовательных методик.

В статье проведен анализ основных факторов понятия «профессионализм» применительно к музыкальной педагогике, выявляет его основные аспекты. Рассмотрены современные концепции и основные аспекты обучения в ДШИ в дополнительном образовании применительно к предметам музыкально теоретического цикла. В статье так же представлены преимущества и методы проведения открытых уроков в музыкальной школе.

В заключении статьи определены преимущества проведения открытого урока, который будет способствовать созданию подлинно профессионально и целостного значимого урока.

\section{ABSTRACT}

The purpose of the article is to consider modern achievements in the field of music and pedagogical research, educational methods. The article analyzes the main factors of the concept of "professionalism" in relation to music pedagogy, reveals its main aspects. The modern concepts and the main aspects of teaching in the secondary school in additional education in relation to the subjects of the musical and theoretical cycle are considered. The article also presents the advantages and methods of conducting open lessons in a music school. In conclusion, the article identifies the advantages of conducting an open lesson, which will contribute to the creation of a truly professional and holistic meaningful lesson.
\end{abstract}


Ключевые слова: музыкальное образование, Детская школа искусств, Детская музыкальная школа, открытый урок, сольфеджио, профессионализм, педагогики, учащиеся.

Keywords: music education, Children's art school, children's music school, open lesson, solfeggio, professionalism, pedagogy, students.

На современном этапе музыкальное образование представляет собой систему, которая включает в себя музыкальное воспитание, развитие и обучение [1, с. 12]. Действующая в нашей стране система музыкального образования включает в себя как общее музыкальное образование, так и дополнительное. К дополнительному музыкальному образованию относятся Детские музыкальные школы (далее - ДМШ), Детские школы искусств (далее - ДШИ).

В ДШИ и ДМШ учебный процесс осуществляется путем внедрения дополнительных художественно-эстетических образовательных программ, которые направлены на воспитание у учащихся любви и интереса к музыке, на формирование активных музыкально-слуховых представлений и развитие практических музыкальных навыков - аналитических, слуховых и исполнительских. Несмотря на имеющиеся преимущества комплексного обучения, которое получают дети на занятиях теоретического цикла в курсе ДШИ и ДМШ, основная задача которого заключается в одновременном формировании всех музыкальных способностей учащихся: слуха, творческого воображения, чувства ритма, памяти. [4, с. 55]. На современном этапе музыкально-теоретические дисциплины теряют популярность и востребованность у учащихся. Поэтому актуальным направлением изучения практики преподавания данных дисциплин считается изучение авторских методик и различных форм музыкальнопедагогической деятельности, изучение лучшего творческого опыта ведущих педагогов теоретиков, которые направлены на повышение интереса учащихся к предмету.

Первоочередным компонентом музыкального образования считается высокий уровень профессионализма преподавателя. В области передачи профессиональных знаний сложившаяся в музыкальной педагогике система взаимодействия, через проведение открытых уроков и мастерклассов общеизвестна. Понятия «профессионализм, «открытый урок», педагогическое мастерство» рассматриваются как единое целое, потому что открытый урок показывает авторские наработки педагога по своему предмету и уровень его профессионализма актуализирует весь накопленный им ранее опыт, умения и знания. В процессе подготовки и проведения открытого урока к преподаваемому предмету формируется 
высокопрофессиональное отношение. На рисунке 1 представим основные характеристики открытого урока.

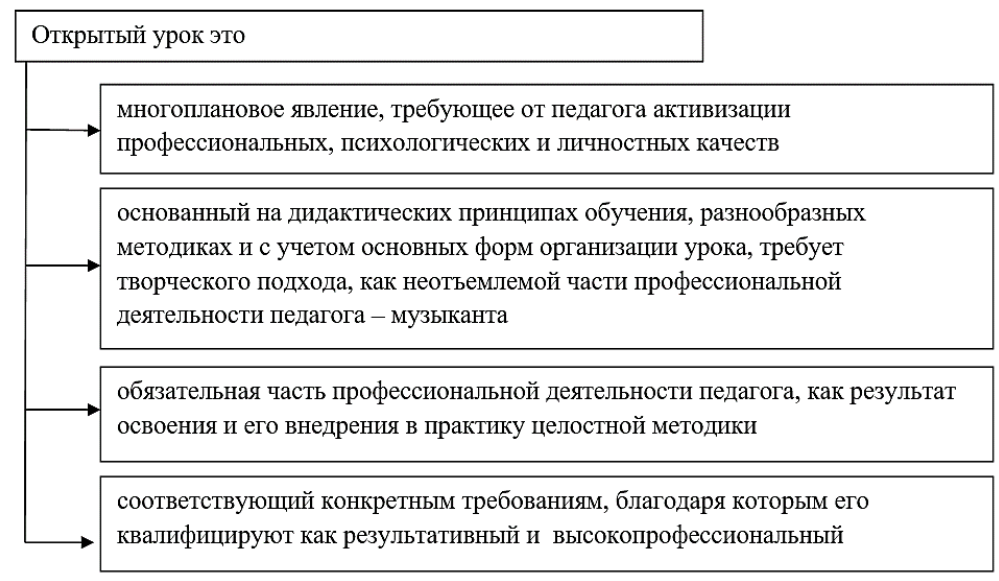

\section{Рисунок 1. Основные характеристики открытого урока}

В современной музыкальной педагогике вопрос проведения и подготовки открытых уроков по предметам образовательного цикла в ДШИ и ДМШ изучен мало, обозначим основные методические задачи и определим наиболее значимые этапы проведения и подготовки высокопрофессионального урока сольфеджио с учетом достижений современной педагогики на основе имеющихся методик музыкально-теоретического цикла [3, с. 67].

Для этого необходимо решить задачи:

- изучение музыкальной педагогики в общем и дополнительном музыкальном образовании (подходы, методы и формы к обучению музыке);

- выявление востребованных методик преподавания в образовательном процессе теоретических дисциплин и изучение их практического применения;

- определение основные компонентов и выявление важных аспектов при проведении и подготовке открытых уроков по теоретическим дисциплинам;

- изучение и обобщение существующего музыкально-педагогического опыта, опыта проведения открытых уроков по теоретическим дисциплинам в ДМШ и ДШИ. 
В музыкально-педагогической системе главенствующая роль принадлежит инновационным процессам, которые затрагивают различные сферы образования; неотъемлемой частью педагогической работы считается исследовательская деятельность, основанная в изучении разностороннего опыта в научно-методической литературе и педагогической сфере с целью применения достижений в практической деятельности; важность проектировочной роли в музыкальной педагогике, которая заключается в планировании задач и целей музыкально-творческой и педагогической деятельности; эффективность конструктивной и организаторской деятельности педагога, которая заключается в методически грамотном построении уроков, в креативности педагогического мышления, помогающем к решению учебно-воспитательных задач подходить с разных точек зрения; психолого-педагогическое и коммуникативное направление в педагогической деятельности, современная педагогическая деятельность основываться должна на применении успешных психотехнологий, в установлении на уроке взаимоотношений с учащимися с точки зрения педагогической экологии.

Подводя итоги изучения научно-методических трудов в области музыкальной педагогики отметим: успешность воплощения педагогической концепции зависит от педагогической обученности и профессиональной подготовленности, основанной на непрерывном обновлении содержания образования, методов и форм обучения, а также на непрерывной интенсификации учебного процесса.

В связи с изменившимися требованиями к музыкальному образованию детей в XXI веке появилась необходимость дальнейшего усовершенствования учебных планов, методик и программ, ориентации их на решение проблем, выдвигаемых музыкальной современной педагогикой. [2, с. 38]. Педагоги-практики в настоящее время, осознавая важные задачи, которые стоят в сфере преподавания сольфеджио перед профессиональной деятельностью, используют пути улучшения качества преподавания предмета и внедряют инновационные методы и приемы работы в образовательный процесс. Сольфеджио это урок, который продолжает оставаться основной формой обучения и имеет ряд специфических особенностей. Являясь результатом творческого поиска, музыкальный урок в себе сочетает неповторимость искусства, гуманитарнодеятельностный подход и художественное содержание к освоению поставленных в учебном процессе задач.

Особый интерес на таких занятиях вызывает индивидуальная педагогическая техника, та именно взаимодействие профессиональных различных умений, которые и считаются базовым компонентом педагогического мастерства. 
Поэтому к открытым урокам при проведении музакального обучения предъявляются требования:

- открытый урок должен отличается новизной (иметь свое «творческое лицо»);

- успешность открытого урока зависит от естественности поведения учителя, который будет работать сосредоточенно и увлеченно;

- учащиеся должны быть заинтересованы в предмете и стремится к познавательной деятельности;

- должны быть отобраны материалы, способствующие решению проблемно-поисковых задач, потому что их успешное решение учениками будет основным смыслом урока;

- план урока составляется с учетом времени на каждую форму работы и указанием аспектов учебной деятельности педагога и учащихся на конкретном этапе урока;

- учебный материал урока должен содействовать раскрытию темы и повышению его результативности;

- проведение и подготовка открытого занятия предполагает использование и владение педагогом разнообразных и многосторонних методик, при этом необходимо учитывать, что методика преподавания предмета отвечает на вопросы о способах обучения, а учебный процесс это единый и двусторонний акт, совместного творчества преподавателя и учащихся.

Все эти составляющие в своем единстве способствуют созданию подлинно профессионально и целостного значимого урока.

\section{Список литературы:}

1. Арчажникова Л.Г. Профессия - учитель музыки: книга для учителя - М.: «Просвещение», 1984. - 111 с.

2. Барбазюк Т.О. Развитие отечественного начального музыкального образования как проблема музыкознания - Магнитогорск, 2008. - 246 с.: ил. РГБ ОД, 61 09-17/10.

3. Крюкова В.В. Музыкальная педагогика / В.В. Крюкова - Ростов на Дону. «Феникс», 2002 - 281 с.

4. Холопова В.Н. Музыка как вид искусства: учеб. пособие - СПб.: изд-во «Лань», 2000. - 320 c. 


\title{
СТРАТЕГИИ ОБУЧЕНИЯ КАК ВАЖНОЕ УСЛОВИЕ ДЛЯ РАЗВИТИЯ АВТОНОМНОГО ОБУЧЕНИЯ
}

\author{
Мирзаев Дилмуроджсн Тулкинжсон угли \\ магистрант, \\ Ферганский государственный университет, \\ Республика Узбекистан, г. Фергана
}

Гиздулин Эльдар Фатихович

магистрант, Ферганский государственный университет, Республика Узбекистан, г. Фергана

В западной литературе по дидактике иностранного языка термин «автономное обучение» является актуальным примерно с 1980 года. Учащиеся должны иметь возможность самостоятельно определять цели, содержание и процессы обучения, а также выбирать собственные методы и техники обучения. Они также должны самостоятельно оценивать свои успехи в обучении. Эта новая дидактическая концепция автономного обучения направлена на поддержку преподавателей и обучающихся в развитии их культуры преподавания и обучения.

На сегодняшний день вопрос обучения - один из самых приоритетных. Авторы учебников, учебных пособий и программ, преподаватели, как и сами учащиеся, интересуются новыми стратегиями и методами обучения. Требуется саморегулируемое обучение, где обучающийся берет на себя ответственность за итоговый результат. В этом контексте методы и стратегии обучения тематизированы, а учащиеся рассматриваются как „субъекты" собственного обучения, которые - в идеале - автономно, даже вне школы, организовывают свое собственное обучение, планируя, конструируя и контролируя его [1].

Концепция автономного обучения представляет собой способность учащегося самостоятельно принимать решение о процессе собственного обучения, его формы, методах проведения и оценки независимо от преподавателя, учебного материала или учебного заведения. Для достижения этой цели решающую роль играет использование стратегий обучения. Стратегии обучения представляют собой значительный и необходимый компонент автономного обучения, являются основой и инструментом для создания саморегулируемого обучения. 
Знание стратегий обучения и способность эффективно их использовать позволяют учащемуся выбирать содержание своего обучения, целенаправленно, эффективно и структурированно формировать процесс обучения в соответствии с его целями и проверять собственный прогресс [2].

Существуют различные трактовки понятия «стратегии обучения», так же, как и для понятия «автономное обучение». Термин «стратегии обучения» в настоящее время не имеет однозначного определения в специальной литературе, поэтому появилось множество толкований понятия «стратегии». Для некоторых ученых «стратегии обучения» - это «последовательность действий для достижения цели обучения» или «действия, которые учащиеся осуществляют с целью улучшения своей компетенции». Другие ученые понимают под стратегиями обучения «правила принятия решений по выбору подходящих методов и средств достижения цели» или «знание стратегий» [3]. Поэтому необходимо ознакомиться с определения, данными разными учеными.

Стратегии обучения не только помогают учащимся повысить эффективность обучения и работы, но и способствуют формированию независимости учащихся. Учащиеся, владеющие неэффективными стратегиями обучения, остаются зависимыми от преподавателя. Они ждут инструкций или требований преподавателя о том, какие упражнения и задачи изучать или выполнять. У них нет возможности собственного подхода к упражнениям, потому что они не знают или не научились определять, являются ли данные упражнения или задачи наиболее эффективными для обучения.

Знание стратегий обучения и умение их эффективно использовать могут помочь учащимся избежать неэффективные методы обучения и его рутинной однообразности. Практика преподавания показывает, что некоторые учащиеся в процессе изучения иностранного языка используют определенные стратегии обучении, которые часто рассматриваются как неэффективные. Использование неподходящих стратегий может стать причиной неудачи изучающих язык. Поэтому для учителя очень важно помочь учащимся отказаться от этих неэффективных, несоответствующих стратегий обучения.

При использовании стратегий обучения важно, чтобы учащийся осознавал, что он делает, как он решает задачу и было ли это решение успешным или функционирует ли выбранная стратегия и может ли она быть использована в следующий раз со схожим заданием.

Стратегии обучения не только помогают учащимся повысить эффективность обучения и работы, но и способствуют формированию независимости учащихся. Учащиеся, владеющие неэффективными 
стратегиями обучения, остаются зависимыми от преподавателя. Они ждут инструкций или требований преподавателя о том, какие упражнения и задачи изучать или выполнять. У них нет возможности собственного подхода к упражнениям, потому что они не знают или не научились определять, являются ли данные упражнения или задачи наиболее эффективными для обучения. Это подтверждает и Биммель:

«Чем более обширен и разнообразен комплекс учебных стратегий, которым владеют учашиеся, тем самостоятельнее они могут подходить к задачам и тем более независимыми они будет от учителя или от учебных пособий» [4].

Кроме того, изучение стратегий обучения дает учащимся возможность самостоятельно учиться и в дальнейшем. Стремительное техническое развитие, а также связанные с ним способы накопления информации, требуют от каждого человека постоянного обучения. На работе или во время обучения, или в личной жизни необходимо снова и снова собирать, записывать новую информацию, упорядочивать ее и систематизировать. Учебные заведения не могут подготовить учащихся ко всем последующим жизненным ситуациям. Преподаватель не может передать все, даже порой базовые, знания на занятии. Учащиеся всегда должны учиться чему-то новому, должны пополнять собственный запас знаний. В этом смысле стратегии обучения являются важным фундаментом обеспечения самостоятельное обучение вообще. Они помогают учащимся сделать самообучение более эффективным и успешным для приобретения знаний.

Обучение, направленное на предоставление учащимся знаний об обучении, позволяет им автономно и эффективно формировать процесс собственного обучения, нести ответственность за результат обучения и продолжать учиться дальше. Если преподаватель хочет научить учащихся стратегиям обучения, то большое значение имеет то, что он видит процесс обучения с точки зрения учащегося и распознает различные способы обучения. Кроме того, он должна беспокоиться о том, какие методы хочет использовать, чтобы научить учащихся определенным стратегиям обучения. При использовании стратегий обучения студенты и учителя должны частично переопределять свои роли. Стратегии обучения особенно эффективны, когда учитель отказывается от полного контроля над ходом занятия, выводит себя из центра урока и все чаще перекладывает ответственность на учащегося. Его роль сводится к консультированию и стимулированию. На занятиях, ориентированных на стратегии обучения, преподаватель все чаще берет на себя роль помощника или консультанта по обучению. Преподаватель дает учащимся знания о стратегиях обучения и их использовании, предоставляет им возможности для 
применения и оценки стратегий обучения, тем самым помогает им развивать самостоятельность. Поскольку не все стратегии и методы обучения одинаково подходят для всех учащихся, например, если некоторые из учащихся предпочитают стратегии обучения, а другие - нет, то преподаватель должен принять их выбор. Важным и решающим при использовании стратегий обучения всегда является то, что учащийся знает, какую цель преследуют стратегии обучения и почему они полезна для него.

\section{Список литературы:}

1. Rampillon U. Aufgabentypologie zum autonomen Lernen. Ismaning : Hueber, 2000.

2. Neuner Anfindsen S. Fremdsprachenlernen und Lernerautonomie. Sprachlernbewusstsein, Lernprozessorganisation und Lernstrategien zum Wortschatzlernen in Deutsch als Fremdsprache. Baltmannsweiler: Schneider Verlag Hohengehren, 2005.

3. Chudak S. Lernerautunomie fördernde Inhalte in ausgewählten Lehrwerken $\mathrm{DaF}$ für Erwachsene. Überlegungen zur Gestaltung und zur Evaluation von Lehr-und Lernmaterialien. Frankfurt am Main: Peter Lang, 2007.

4. Bimmel P.Lernstrategien im Deutschunterricht - Funktionen und Vermittlungfragen. In: Fremdsprache Deutsch. Fremdsprachentheorie. 1995. S. 16.

5. Rampillon U. Lerntechniken im Fremdsprachenunterricht 3. Auflage. München: Huber, 1996.

6. Tönshoff W. Lernstrategien // K.-R. Bausch, H. Christ, H.-J. Krumm. Handbuch Fremdsprahenunterricht. Tübingen und Basel: Francke, 2003. S. 331-335.

7. Bimmel P. Lernstrategien im Deutschunterricht. // Fremdsprache Deutsch. Heft 8\& Lernstrategien, 1993. S. 4-11. 


\title{
СЕКЦИЯ 4.
}

\author{
ТЕОРИЯ И МЕТОДИКА \\ ПРОФЕССИОНАЛЬНОГО ОБРАЗОВАНИЯ
}

DOI: $10.32743 / 25419862.2021 .3 .45 .256507$

\begin{abstract}
СОВРЕМЕННЫЕ ТРЕБОВАНИЯ
К КАЧЕСТВУ ОБРАЗОВАНИЯ В КОЛЛЕДЖАХ

И УРОВЕНЬ ОСВОЕНИЯ ПРОФЕССИОНАЛЬНЫХ КОМПЕТЕНЦИЙ ВЫПУСКНИКОВ
\end{abstract}

\begin{abstract}
Богданов Ренат Анверович
преподаватель,

Государственное бюджетное профессиональное

образовательное учреждение города Москвы

Колледж архитектуры, дизайна и реинжиниринга № 26;

соискатель кафедры педагогики и психологии Московского

государственного института культуры,

РФ, г. Химки
\end{abstract}

\section{MODERN REQUIREMENTS FOR THE QUALITY \\ OF EDUCATION IN COLLEGES AND THE LEVEL \\ OF DEVELOPMENT OF PROFESSIONAL COMPETENCIES \\ OF GRADUATES}

Renat Bogdanov

Teacher,

State Budgetary Professional Educational Institution

of the City of Moscow College of Architecture,

Design and Reengineering No. 26;

Candidate of the Department of Pedagogy and Psychology

of the Moscow State Institute of Culture,

Russia, Khimki 


\section{АННОТАЦИЯ}

В статье описываются современные требования к качеству образования в колледжах и уровень освоения выпускниками профессиональных компетенций, показаны основные тенденции развития среднего профессионального образования, отрицательная динамика влияния дистанционного образования на становление профессии современного рабочего класса.

The article describes the current requirements for the quality of education in colleges and the level of development of professional competencies by graduates, shows the main trends in the development of secondary vocational education, the negative dynamics of the influence of distance education on the formation of the profession of the modern working class.

Ключевые слова: среднее профессиональное образование, требования к качеству образования, дистанционное образование, профессиональные компетенции, рабочий класс, рабочая специальность, педагогическая диагностика.

Keywords: secondary vocational education, requirements for the quality of education, distance education, professional competencies, working class, working specialty, pedagogical diagnostics.

Современная образовательная политика задает инновационный вектор развития всему образованию в целом. В этой связи необходимо обогащать образовательный процесс за счет использования новых образовательных технологий, формирующих профессиональные компетенции студентов.

В соответствии с Федеральными государственными образовательными стандартами (актуализированными ФГОС по рабочим профессиям и специальностям) реализация учебного процесса должна строиться на инновационных технологиях обучения, которые служат нормативноправовой и трудовой базой для отработки обучающимися профессиональных навыков, максимально приближенных к реальности.

В сложившихся условиях будет актуальным внедрение деятельностно-компетентностного и практико-ориентированного подходов, которые обуславливают применение активных и интерактивных форм и методов обучения, позволяющих формировать трудовые ресурсы нового типа согласно ФГОС. Вместе с тем, систему среднего профессионального образования нельзя сравнивать со школьной системой, как считают некоторые представители чиновников департаментов образования 
крупных городов, курирующие образовательные системы. Колледж всегда оставался обособленной структурой, выпускающей прежде всего квалифицированные рабочие кадры для нашей страны и ближнего зарубежья, поэтому применение зачастую дистанционных или иных интерактивных форм образования могут самым негативным образом сказаться на профессиональной компетентности выпускника.

Специфика деятельностно - компетентностного подхода современного профессионального образования состоит в подготовке специалистов высокого уровня, предполагающего не только вооружение обучающихся определенным набором знаний, умений и навыков в выбранной сфере, но и становление личности будущего профессионала, способного к индивидуальным креативным решениям, к самообучению [1].

В настоящее время можно выделить следующие тенденции развития системы профессионального образования:

- интеграция образования, науки и производства;

- проектно-целевой подход к организации профессионального образования;

- развитие креативного характера профессионального образования;

- формирование и развитие региональных систем непрерывного профессионального образования;

- взаимодействие рынка образовательных услуг с рынком труда;

- повышение качества профессионального образования [2].

В колледже анализ и решение производственно-технических ситуаций могут выполняться на практических занятиях как один из видов практических работ, в качестве внеаудиторных занятий, в процессе производственной или преддипломной практики при решении комплексных производственных задач. Выполнение заданий по анализу и решению производственно-технологических ситуаций может проходить индивидуально или группами по три-пять человек с последующим коллективным обсуждением намеченных выводов [3].

Мы полагаем, что современному среднему профессиональному образованию недостает достаточного уровня диверсификации, то есть расширения перечня образовательных программ с учетом специфики направления специальности, расширения спектра оказываемых образовательных услуг таких, как например обучение смежным профессиям. И хотя правительством непрерывно производится анализ рабочих профессий, зачастую ни предприятиям, ни ведущим колледжам городов не хватает в достаточном количестве учебно - материальной базы. Структура профессионально - квалификационного состава рабочих на производстве на сегодняшний день настолько разнится, что наблюдается полное или частичное несоответствие уровня подготовки рабочих 
требованиям научно - технического прогресса. Это связано с тем, что во многом не учитываются подходы к профессиям, связанные с различными уровнями механизации и автоматизации производства таких основных направлений подготовки как монтаж систем вентиляции, монтаж систем водоснабжения и водоотведения, отопления, монтаж теплотехнического оборудования и оборудования тепловых сетей. Все эти уровни подготовки чрезвычайно важны и востребованы в современных условиях подготовки рабочего класса большинства российских мегаполисов.

Уровень освоения профессиональной компетенции выпускников среднего профессионального образования должен показывать прежде всего эффективность решения производственно-технических задач, используемых как практические методы подготовки специалистов.

Следует также отметить, что в современных реалиях в условиях проведения дистанционного обучения, связанного с пандемией коронавируса, кардинально изменяется отношение студентов к знаниям. На наш взгляд, в подобных условиях качество профессионального образования продолжает снижаться. Зачастую проблемы дисциплины могут быть дополнены разным уровнем усвояемости знаний различных студентов. При этом во главу угла ставится самостоятельная работа обучающегося, самоорганизация его учебной деятельности. Задача преподавателя в рамках дистанционного обучения сводится в большей степени в сопровождении студента по предмету, принятия мер ориентации в специфике предмета. Необходимо при этом отметить, что в условиях современного дистанционного обучения учебно - воспитательный процесс уже не является среди студентов колледжа ключевым фактором получения профессиональных знаний. Его заменяет самовоспитание и самоподготовка.

В связи с корректирующими воздействиями на профессиональное образование необходимо постоянно проводить педагогическую диагностику с целью установления и изучения признаков, характеризующих состояние процесса дистанционного обучения на современном этапе, строить пути прогнозов образовательного процесса в целом, корректировать процесс обучения в целях повышения качества подготовки квалифицированных рабочих и специалистов.

Одновременно студенты могут сталкиваться с большим количеством проблем социального и профессионального характера, требующих от них осознанного и ответственного выбора в соответствии с личностными предпочтениями.

Как полагает Клеменьтева И.Н., система качества образования в учреждениях среднего профессионального образования является 
комплексом разработанных нормативно-методических документов, определяющих содержание, технологии, методы и средства работы всех должностных лиц, преподавателей и студентов по дальнейшему повышению качества образовательного процесса и профессиональной компетентности выпускников техникума. Она позволяет разработать политику, цели гарантии качества, пути достижения этих целей и является основой постоянного улучшения всех процессов [8].

В то же время Клеменьтева И.Н. считает, что в обеспечении качества среднего профессионального образования можно выделить следующие аспекты:

- первый - политика в области среднего профессионального образования, направленная на повышение его качества;

- второй - установленные, принятые обществом и государством критерии, нормативы, стандарты качества образования;

- третий - механизмы и инструменты управления и самоуправления среднего специального учебного заведения с позиций качества;

- четвёртый - объективные условия, способствующие достижению качества образования: качественный уровень подготовки преподавателей и студентов, качество учебных программ, дидактических и методических материалов, уровень материально-технической базы, социально-бытовой и информационной структуры учебного заведения;

- пятый - конкретные технологии организации учебного и воспитательного процессов, методы оценки качества обучения на различных этапах.

Вместе с тем, закономерности педагогического процесса не всегда позволяют реализовать объективно перечисленные Клеменьтевой И.Н. аспекты повышения качества образования. На наш взгляд, перед уточнением и описанием аспектов качества образования необходимо понимать тесную взаимосвязь построения теоретической и практической учебной деятельности студентов колледжа, а также методологию обеспечения конкретной образовательной рабочей специальности. Приведем несколько доводов и проанализируем их.

Во-первых, политика в области среднего профессионального образования, направленная на повышение его качества не всегда реализуется на практике достаточно полно. Несмотря на требования нормативных документов, положений, раскрывающих сущность и динамику распространения политики качества образования, на наш взгляд, только ведущие колледжи Москвы и других мегаполисов России получают должное финансирование и поддержку со стороны соответствующих ведомств и департаментов образования. Таким образом, те положения, 
что отражены в законе об среднем профессиональном образовании, в большей мере остаются лишь на бумаге.

Во-вторых, установленные, принятые обществом и государством критерии, нормативы, стандарты качества образования реализуются не в полной мере, а лишь по мере необходимости и только для того, чтобы осуществить демонстрацию умений и навыков, которыми должны обладать выпускники колледжей, тогда как большинство выпускников и студентов младших курсов получают лишь базовое образование, не закрепленное должными практическими навыками.

В- третьих, имеют место объективные условия, не способствующие достижению качества образования, заключающиеся прежде всего в низком уровне подготовки или переподготовки преподавательского состава что в итоге ведет к снижению качества составления и наполнения учебных программ, дидактических и методических материалов.

B- четвертых, принципы педагогического процесса в профессиональном образовании, заключающиеся в созидании основных требований к обучению и методам педагогического воздействия в наше время зачастую опираются на гуманитаризацию образования, препятствуя с одной стороны малейшему проявлению технократизма, а с другой чрезмерному уделению внимания человеку и духовным ценностям. Когда речь идет о рабочих профессиях, необходимо принимать во внимание что реализация педагогического процесса в этом направлении среднего профессионального образования должна предусматривать образ мыслей современного рабочего, стилистику поведения в сложных производственных ситуациях, общее взаимодействие в социокультурном пространстве. Всеобщая и повсеместная гуманитаризация образования так широко популярная в настоящее время, по нашему мнению, основной своей целью ставит не столько профессиональное становление личности рабочего класса, сколько преследует цели восполнения духовного вакуума и формирования устойчивой социальной идеологии.

В заключении хотелось бы отметить, что в настоящее время при формировании профессиональных компетенций выпускников колледжей педагогам важно применять аксиологические подходы в образовании и обучении подрастающего поколения, прививать истинные педагогические ценности будущему рабочему классу. Педагог среднего профессионального образования должен прежде всего трезво оценивать педагогические перспективы с учетом своевременных инноваций и направлений развития по преподаваемой дисциплине, осознавая в то же время специфичность российской экономики в современных условиях.

Анализ рабочих профессий на сегодняшний день показывает, что большинство предприятий обладают учебно - материальной базой и 
обеспечивают репрезентативность выборочного исследования номенклатуры рабочих профессий. Проблема заключается в том, что профессионально - квалификационная характеристика студентов колледжей сегодня во многом не всегда соответствует нормативным показателям. Соответствие уровня подготовки рабочих требованиям научно технического прогресса зачастую соблюдается в основном на крупных промышленных предприятиях, имеющих свои собственные образовательные ресурсы и оказывающие собственные образовательные услуги. В учреждениях же профессионального образования выпускник имеет лишь базовые, основные понятия в своей профессии и зачастую не может ориентироваться в частных, конкретных производственных ситуациях. Как следует из вышеописанного, необходима повторное обучение выпускника уже на производстве, а это требует времени, сил и средств затрачиваемого в уже готового специалиста, окончившего колледж. Как правило, такая позиция не устраивает современных работодателей.

\section{Список литературы:}

1. Богданова М.В. Чебанов К.А., Формирование профессиональных компетенций обучающихся колледжа. Современные проблемы науки и образования. -2016 . - № 4.

2. Профессиональная педагогика: учебник для студентов, обучающихся по педагогическим специальностям и направлениям. Под ред. С.Я. Батышева, А.М. Новикова. Изд. 3, перераб.М.: Изд - во ЭГВЕС,2009.- 456 с.

3. Коняева Е.А., Павлова Л.Н. Краткий словарь педагогических понятий: учебное издание/Е.А. Коняева, Л.Н. Павлова. Челябинск: изд- во Челяб. гос. пед. ун-та, 2012. -131 с.

4. Российское образование. федеральный портал. режим доступа: https://edu.ru/.

5. Портал федеральных учебно-методических объединений в среднем профессиональном образовании. режим доступа: https:/fumo-spo.ru/

6. Профобразование. Режим доступа: http://проф-обр.pф/.

7. Сопровождение деятельности ФУМО СПО по внедрению новых и актуализированных ФГОС СПО. режим доступа: http://spo-edu.ru/fgos.

8. Клеменьтева М.Н. Обеспечение качества профессионального образования студентов с учетом требования ФГОС СПО. Режим доступа: https:/nsportal.ru/npo-spo/transportnye-sredstva/library/2019/09/25/statyaobespechenie-kachestva-professionalnogo. 


\title{
СИСТЕМА РЕЙТИНГОВОЙ ОЦЕНКИ КАЧЕСТВА ЗНАНИЙ СТУДЕНТОВ
}

\author{
Горбунова Татьяна Валерьевна \\ канд. пед. наук, дои. кафедры \\ педагогики и методики начального образования, \\ Чувашский государственный педагогический университет \\ им. И.Я. Яковлева, \\ $P \Phi$, г. Чебоксары
}

В связи с внедрением новых государственных образовательных стандартов и инновационных технологий обучения в практику подготовки будущих педагогов возникла необходимость использования новых подходов в системе оценки качества знаний студентов. Для организации текущего контроля и управления учебным процессом в вузах начали использовать рейтинговую систему оценки успеваемости обучающихся.

Рейтинг в переводе с английского означает «числовой или порядковый показатель, отображающий важность или значимость определенного объекта или явления».

Рейтинг, в книге «Педагогические технологии» Кукушина В.С., определяется как «сумма баллов, набранная студентом в течение некоторого промежутка времени, рассчитанная по определенным формулам, не изменявшимся в течение этого промежутка» [2, с. 11].

Главная задача рейтинговой системы заключается в повышении мотивации обучающихся к освоению образовательной программы путем более высокой дифференциации оценки их учебной работы.

Технология рейтинговой оценки качества знаний обучающихся по отдельным дисциплинам такова:

- дисциплина разбивается на разделы (модули). Для того чтобы избежать чрезмерной нагрузки обучающихся рекомендуется равномерное распределение учебной деятельности, а также контрольных проверок в течение семестра, что также будет способствовать равномерному набору баллов;

- в конце семестра подсчитывается общее количество набранных баллов. Положительную оценку по текущей аттестации обучающийся может получить, если сумма баллов от 30 до 60 при условии, что ему зачтены все плановые задания и им пройдены все контрольные испытания;

- по окончании каждого курса определяется годовой рейтинг обучающегося. Если он на зачете или экзамене набирает менее 20 
баллов или общий балл по итогам семестра казывается менее 60 , то рейтинговая оценка по дисциплине в ведомости успеваемости не проставляется, а проставляется оценка «неудовлетворительно».

Такая технология оценки качества знаний однозначно стимулирует учебную деятельность обучающихся в период изучения дисциплины, помогает устанавливать обратную связь. Итоговая отметка объективна и исключает претензии студента к преподавателю. Однако подобное оценивание требует от преподавателя особого подхода к выбору методов, форм организации подготовки будущих педагогов. Для обеспечения систематического контроля за учебной деятельностью и объективной оценки качества усвоения материала преподавателю необходимо:

- весь учебный материал по дисциплине разделить на модули;

- после окончания изучения модуля определить уровень усвоения материала каждым студентом и выставить рейтинговую оценку;

- в конце курса выставить общую оценку за работу, представляющую собой сумму рейтинговых оценок за отдельные модули.

Практика показывает, что главным в реализации рейтинговой системы оценки качества знаний является проведение систематического контроля уровня знаний и умений обучающихся.

Особое внимание хотелось бы обратить на то, что во время первой встречи со студентами преподавателю необходимо четко объяснить суть и технологию рейтинговой системы оценки знания именно по данной дисциплине. Ознакомить с модулями дисциплины, с оценочной шкалой, методикой выставления баллов за выполненное задание. В этом случае рейтинговая система будет успешно применяться, так как понятна не только преподавателю, но и самим обучающимся.

Рассмотрим основные компоненты рейтинговой системы оценки качества знаний на примере дисциплины «Педагогика». Весь учебный материал по данной дисциплине разделен на два модуля - крупных раздела. За усвоение каждого модуля студент получает определенное количество баллов (максимальное количество по одному модулю 30 баллов).

В каждом модуле несколько видов учебной деятельности, соответствующих требованиям профессиональной подготовки будущих педагогов. Оценивается посещение лекционных и практических занятий, конспектирование первоисточников, выполнение творческого задания, самостоятельная работа, написание реферата, результат тестирования. За каждое посещение лекции и аккуратное конспектирование выставляется от 0 до 1 баллов в зависимости от качества. Студенту, пропустившему лекцию по неуважительной причине, баллы не начисляются, а если по уважительной причине и конспект по пропущенной теме 
подготовлен, студент получает 0,5 балла. Посещение практического занятия, при наличии конспекта по всем вопросам, которые будут обсуждаться во время занятия, оценивается в 1 балл. Дополнительные баллы начисляются за доклады по вопросам, за активное участие в обсуждении проблемы студент может получить дополнительно ещё 12 балла. По нескольким темам модулей предусмотрено выполнение творческих заданий. Практика показывает, что выполнение таких заданий активизирует и интенсифицирует процесс обучения, в достаточной степени стимулирует мотивы учебной деятельности студентов, устраняет пропасть между обучением и реальными жизненными ситуациями, позволяет развивать творческий потенциал личности будущих педагогов $[1,103]$. За выполнение творческих заданий можно получить от 1 до 3 баллов.

Отдельно оценивается самостоятельная работа (аудиторная или внеаудиторная). Она может выполняться как индивидуально, так и в парах. При выполнении работы в паре каждый студент получает установленное для индивидуальной работы количество баллов от 1 до 3.

В каждом модуле предусмотрено проведение письменной работы, которые оцениваются максимум в 3 балла. Изучение модуля завершается тестированием, за которое можно получить максимум 5 баллов.

Для того чтобы обеспечить обучающимся возможность получить дополнительные рейтинговые баллы, предусмотрены поощрительные баллы, начисляемые за дополнительную внеаудиторную работу: выполнение индивидуальных заданий различного характера, в том числе подготовка реферата по актуальной проблеме в области педагогики. Поощрительные баллы начисляются за участие в олимпиадах по педагогике различного уровня, за выступление с научными докладами на научно-практических конференциях, за написание научной статьи. Таким образом, максимальное количество баллов, которые может заработать обучающийся по каждому модуль 30 , а положительную оценку по дисциплине в ходе текущей аттестации он получает при сумме баллов в пределах от 30 до 60.

Изучение дисциплины завершается экзаменом или зачетом. Они являются промежуточной аттестацией по дисциплине. Сроки их проведения определяются факультетом, в соответствии с графиком учебного процесса. К промежуточной аттестации допускается студент, набравший по дисциплине 30-60 баллов.

Для получения по дисциплине зачета или удовлетворительной оценки обучающемуся в семестре по итогам текущей и промежуточной аттестаций в сумме необходимо набрать не менее 60 баллов. Рейтинговая оценка по дисциплине заносится в ведомость, однако в зачетной 
книжке выставляется только оценка по 5-балльной системе. Анализ научной педагогической литературы, а также нормативно-правовых документов высших учебных заведений показывает, что соответствие между стобальной шкалой и пятибалльной шкалой в различных вузах разняться.

Ещё один момент, на который хотелось бы обратить внимание, что в Приложении к диплому, в которое вносятся результаты аттестации по всем видам учебной деятельности, предусмотренным учебным планом: учебным дисциплинам, педагогическим практикам, итоговому государственному экзамену, выполнению и защите выпускной квалификационной работы все оценки проставляются только по 5-балльной шкале.

Семестровый рейтинг определяется как средний рейтинг по всем дисциплинам и видам учебной деятельности обучающегося в семестре, предусмотренным учебным планом. Рейтинг за учебный год определяется из семестровых рейтингов и рейтинга по практике. Общий рейтинг складывается из годовых рейтингов и рейтинга студента по результатам государственной аттестации.

Рейтинговые аттестации по дисциплинам проводятся в каждом семестре и включают текущую и промежуточную составляющие. К аттестации по дисциплине приравнивается аттестация по курсовым работам. При выставлении рейтинговой оценки по курсовой работе оценивается деятельность обучающегося в период её выполнения и защиты. Аттестация по практике проводится в процессе её прохождения и отчета по ней. Все оценка выставляются по 100-балльной шкале. Итоговые государственные экзамены по направлениям подготовки, подготовка и защита выпускных квалификационных работ также оцениваются по 100-балльной шкале.

Результаты подсчета рейтингов обучающихся используются при определении рейтинга студенческой группы, курса, профиля и факультета. Результаты проведенного нами опроса показывают, что студенты положительно относятся к рейтинговой системе оценки качества знаний. Они считают, что использование такой системы оценки делает процесса обучения открытым: обучающийся сам может влиять на свой рейтинг, может заработать дополнительные баллы, наблюдать динамику своих результатов. У них формируются такие качества как целеустремленность, упорство, укрепляется чувство собственного достоинства; появляется стимул учиться лучше. Преподаватели отмечают следующие положительные стороны внедрения рейтинговой системы оценивания качества знаний: улучшилась учебная дисциплина, повысилась заинтересованность студентов в результате обучения. Таким образом, можно сделать вывод 
том, что данная система успешно заменила традиционную систему оценки, контроля и учета знаний студентов.

\title{
Список литературы:
}

1. Горбунова Т.В. Мотивационно-ценностный аспект профессиональной готовности будущих социальных педагогов к работе в условиях сельского социума // Вестник Чувашского государственного педагогического университета им. И.Я. Яковлева. - 2015. - № 3 (87). - С. 97-103.

2. Кукушин В.С. Педагогические технологии : учеб. пособие для студентов педагогических специальностей - Ростов-на-Дону : Марта, 2002. - 320 с.

\section{ПРИМЕНЕНИЕ ИННОВАЦИОННЫХ МЕТОДИК И ТЕХНОЛОГИЙ КАК НЕОБХОДИМОЕ УСЛОВИЕ ПОДГОТОВКИ ВОЕННОГО СПЕЦИАЛИСТА}

\author{
Дубинина Елена Александровна \\ мл. науч. сотр. \\ Военной академии ракетных войск \\ стратегического назначения, \\ РФ, Московская обл., г. Балашиха
}

Система подготовки военного специалиста к функциональной профессиональной деятельности актуализировала требования к научной организации учебного процесса, объединяющего различные технологии, среди которых развивающие, проблемные, программные, компьютерные и др.

В основе такой организации лежит применение различных технических средств, позволяющих сократить время изложения нужной информации с применением современных технологий, облегчающих подачу материала и способствующих более эффективному усвоению, что подчеркивает актуальность рассматриваемой темы.

Так как традиционные технические средства обучения в большинстве ориентированы на пассивный, созерцательный характер усвоения информации, основой системы средств обучения в современном вузе должны стать мультимедийные средства обучения нового поколения, объединяющие в себе все преимущества современных компьютерных технологий, выводящие процесс обучения на качественно новый уровень, соответствующие тому способу восприятия информации, которым отличается новое поколение обучающихся. Среди этих отличий можно 
выделить более высокую потребность в темпераментной визуальной информации, зрительной стимуляции, а также максимальное использование преимуществ современных информационных, коммуникационных и образовательных технологий.

Применение мультимедиа в сфере военного образования сегодня идет уже достаточно успешно и имеет следующие направления: видеоэнциклопедии; интерактивные путеводители; тренажеры; электронные лектории; персональные интеллектуальные гиды по различным научным дисциплинам; системы самотестирования знаний обучающегося; интерактивные доски и т.д.

Одновременное представление информации в аудиальной и визуальной формах с использованием всего богатства средств, представляемых компьютером, позволяет облегчить запоминание материала.

Более того, занятия без использования технических средств и занятия с их применением - это совсем разные вещи. В своей совокупности они служат важным и необходимым условием реализации содержания учебных дисциплин, дают возможность обеспечить формирование у обучающихся полноценных знаний, умений, навыков по специальности, а также способствуют их творческому развитию.

Использование новых средств в процессе подготовки будущих военных специалистов влияет на все компоненты учебного процесса. Во-первых, изменяется характер, место и методы проведения учебных занятий, а также общая деятельность преподавателя и обучающегося.

Сегодня средства компьютерно-информационных технологий являются важным помощником преподавателя в освоении информационных потоков, помогают проиллюстрировать различные процессы и явления.

Далее важно отметить, что лекционные занятия традиционно занимают одно из важных мест в учебном процессе. Разнообразны и формы их проведения. Одной из самых успешных для преподавания является лекция-визуализация (шоу, иллюстрация) в основу которой положено образное восприятие наглядности, которая представлена преподавателем с помощью компьютерных и информационных средств обучения. Проведение данной лекции, подкрепленной мультимедийными средствами, активизирует процесс преподавания и повышает эффективность учебного процесса, расширяет деятельность преподавателя, позволяет достичь большей глубины понимания материала и побуждает к более глубокому усвоению, запоминанию, способствует повышению активности, самостоятельности и интереса к предмету обучения. Использование средств компьютерных и информационных технологий во время проведения лекции-визуализации обеспечивает возможность представления широкого набора различных демонстраций учебного материала 
(видеоизображение, анимационные ролики с аудио-сопровождением, использование фрагментов лекций известных педагогов), а также облегчает процесс восприятия материала благодаря использованию интересных, ярких, запоминающихся образов [2].

Следующей эффективной нетрадиционной формой проведения лекционных занятий, которую возможно использовать во время занятий, является лекция-провокация (лекция с запланированными ошибками), подкрепленная средствами компьютерных и информационных технологий для возможности наглядной иллюстрации проблемной ситуации, повышения уровня внимания и оценки правильности информации для развития критического мышления и личной позиции. Лекция выполняет вместе со стимулирующей функцией и контролирующую, поскольку позволяет преподавателю оценить качество усвоения материала, а обучающимся проверить себя и продемонстрировать знания по предмету. Поэтому ее целесообразно проводить как итоговое занятие по теме (разделу) после формирования базовых знаний и умений (с целью контроля) или в неподготовленной аудитории (с целью диагностики того, какие знания и умения обучающимся необходимо приобрести) [4].

На наш взгляд, акцент необходимо сделать еще на одной активной форме предоставления лекционного материала, а именно проведение лекции-ситуации, подкрепленной средствами компьютерно-информационных технологий, для более эффективного понимания обучающимися представленной информации, побуждение к решению проблемных ситуаций и подготовке к глубокому восприятию материала. Во время лекции преподавателем используются в качестве фактографической информации заранее подготовленная ситуация (реальная или сконструированная) для детального исследования и решения представленной проблемы.

В качестве организационных форм обучения и воспитания, с учетом инновационной направленности образовательного процесса, необходимо отметить активное использование такой формы занятия, как лекция-пресс-конференция.

Важное место в учебном процессе занимают семинары. В идеале их можно проводить с широким использованием ролевых игр, технологии «круглый стол», «открытая кафедра».

Высокий потенциал в плане образовательных возможностей будущих специалистов в сфере высшего военного образования имеет такая технология, как «педагогическая мастерская», в процессе проведения которой каждый обучающийся - равноправный участник дискуссии по обсуждаемому вопросу [1.С.12]. 
Несмотря на разнообразие технических средств, и технологий, использующихся в учебном процессе, следует отметить, что качество обучения зависит, прежде всего, от совершенства учебного материала, формы его представления и организации учебного процесса. Так, например, при разработке модели учебных презентаций необходимо соблюдение ряда принципов: слайд-фильм должен задавать ритм прохождения материала и иметь специальные аудиовизуальные средства управления восприятием материала; динамика предъявления текста задается преподавателем (это происходит либо заранее при разработке слайд-фильма, либо в процессе демонстрации); слайд-фильм предлагает обучающимся свою логику изучения материала; допускаются перекрестные ссылки. Поэтому, в традиционной схеме обучения возникает много проблем, связанных с постоянно нарастающим потоком новой информации, усложнением знаний, отсутствием иллюстративного материала. В этих условиях акцент на интенсивную самостоятельную работу не дает положительных результатов по тем же причинам. Появление мультимедиа средств и технологий позволяет решить эти проблемы. Внедрение электронных учебно-методических обучающих средств в учебный процесс не только освобождает преподавателя от рутинной работы в организации учебного процесса, оно дает возможность создать богатый справочный и иллюстративный материал, представленный в самом разнообразном виде: текст, графика, анимация, звуковые и видеоэлементы. При отсутствии технических возможностей наглядного представления материалов, простейшими средствами визуального воздействия на обучающихся являются плакаты, реже материальные модели и совсем редко специальные кино-видео фильмы. При сравнительном анализе недостатки этих средств очевидны, а возможности мультимедийных учебных презентаций объективно шире. Основным способом повысить количество воспринимаемой информации является повышение наглядности. Возрастающая плотность информационного потока вынуждает максимально задействовать все каналы восприятия обучаемых. Следовательно, наибольшее внимание необходимо уделять зрительной составляющей теоретического курса, в противовес слуховой составляющей (голосу лектора), которая может иметь вторичное значение. Учебные видео-презентации позволяют представлять усваиваемый материал максимально детально и подробно, дробя его на порции, имеющие оптимальную информационную насыщенность и наглядность, а также совмещать указанное дробление со структурированием. Помимо этого, электронные видео-презентации позволяют использовать возможности, недоступные обычным плакатам - анимация отдельных элементов, использование видеовставок. Диапазон материалов, которые могут быть использованы в качестве исходных составляющих при разработке мультимедийных наглядных пособий, необычайно широк - начиная от 
иллюстраций в учебниках и имеющихся обычных плакатов, и до самостоятельно полученных фото и видео материалов.

В заключении отметим, что важнейшей задачей сегодняшнего дня является создание целостной системы средств обучения в современном военном вузе, что позволит реализовать механизмы и условия инновационного подхода к готовности военного специалиста в дальнейшем эффективно выполнять военно-профессиональные обязанности.

\title{
Список литературы:
}

1. Сорокопуд Ю.В. Концепция модернизации подготовки преподавательских кадров для высшей школы/Ю.В. Сорокопуд//Мир образования - образование в мире. - 2010 - № 3(39). - 10-15.

2. Минобрнауки России ФГБОУ высшего профессионального образования «Активные и интерактивные образовательные технологии (формы проведения занятий) в высшей в высшей школе», учебное пособие, Нижний Новгород ННГАСУ, 2018 г.

3. Научные ведомости. Серия Гуманитарные науки. 2013. № 27 (170). Выпуск 20 Чикина Ю.Ю. «Особенности использования активных форм организации лекционных занятий с использованием информационных технологий».

4. Проблемы и перспективы развития образования (II): материалы междунар. заоч. науч.конф. (г. Пермь, май 2012 г.). - Пермь: Меркурий, 2012. - vi, $190 \mathrm{c}$.

5. «Современная наука. Диалог естественной-научной и социальногуманитарной субкультур». Сборник научных трудов по материалам Международной научно-практической конференции г. Белгород, 2020 г.

6. Королев Л.М. Психологическое обеспечение профессионального становления военного специалиста: Монография/Л.М. Королев. - М.: Издательско-торговая корпорация «Дашков и К», 2020. - 204 с.

\section{ВОВЛЕЧЕНИЕ БУДУЩИХ БАКАЛАВРОВ СОЦИАЛЬНОЙ РАБОТЫ В СОЦИАЛЬНО-ПРОЕКТНУЮ ДЕЯТЕЛЬНОСТЬ ДЛЯ ФОРМИРОВАНИЯ У НИХ ПЕДАГОГИЧЕСКОЙ КУЛЬТУРЫ}

\author{
Ибрагимов Юсуп Муслимович \\ ассистент кафедры \\ теории и технологии социиальной работь, \\ ФГБОУ ВПО «Чеченский государственнылй университет», \\ $Р \Phi$, г. Грозный
}




\title{
INVOLVEMENT OF FUTURE BACHELORS OF SOCIAL WORK IN SOCIAL PROJECT ACTIVITIES FOR FORMING A PEDAGOGICAL CULTURE IN THEM
}

\author{
Yusup Ibragimov \\ Assistant at the Department \\ of Theory and Technology of Social Work, \\ FSBEI HPE "Chechen State University", \\ Russia, Grozny
}

\begin{abstract}
АННОТАЦИЯ
Профессиональный стандарт социального работника закрепляет многие важные требования, которыми специалист должен овладеть. Одним из важных требований закрепляется умение владеть методами организации ресурсов для оказания помощи нуждающимся гражданам. В основном под указанными ресурсами понимаются возможности социального окружения. Одной из популярных современных форм совместной деятельности является проектная деятельность. Таким образом, социально-проектную деятельность можно охарактеризовать, как одну из экзистенциальных форм профессии социального работника. Поскольку одним из обязательных направлений деятельности специалиста является образовательная деятельность, вполне очевидно, что социально-проектная деятельность определяет и его педагогическую культуру.
\end{abstract}

\section{ABSTRACT}

The professional standard of a social worker sets out many important requirements that a specialist must master. One of the important requirements is the ability to master the methods of organizing all possible resources to provide assistance to citizens in need. Basically, these resources are understood as the capabilities of the social environment. One of the popular modern forms of joint activity is project activity. Thus, social-project activity approaches the existential form of the profession of a social worker. Since one of the obligatory areas of a specialist's activity is educational activity, it is quite obvious that social-project activity determines his pedagogical culture.

Ключевые слова: гибкие компетенции, социально-проектная деятельность, бакалавр социальной работы, педагогическая культура.

Keywords: flexible competencies, social project activity, bachelor of social work, pedagogical culture. 
Содержание деятельности современного специалиста по социальной работе весьма разнообразно. Среди видов деятельности можно отметить медицинскую, правовую, организационную, а также образовательную деятельность [7]. Предметом интереса в рамках текущей работы является подготовка будущего социального работника к осуществлению образовательной деятельности. Речь в первую очередь идёт о формировании у будущего социального работника педагогической культуры, как общего коэффициента всех навыков педагогической деятельности.

Поскольку в предыдущих работах уже были выявлены содержательные основания педагогической культуры социального работника, останавливаться на их повторном анализе излишне. Вместе с тем актуальным аспектом формирования педагогической культуры будущего социального работника является освоением им гибких профессиональных компетенций (“soft skills"). К подобным компетенциям совершенно справедливо относят способность организовывать совместную образовательную деятельность [4; 8].

Стоит отметить, что проектная деятельность в области образования ошибочно воспринимается как нечто инновационное. Проектный метод работы достаточно давно себя положительно зарекомендовал в процессе организации управленческой деятельности. Данное основание и послужило активному продвижению, рассматриваемого метода управления во все возможные виды деятельности граждан. Образовательная сфера вполне закономерно оказалась в числе лидеров популяризации данного метода управления. Понятие «проект» по своему смысловому содержанию отражает явления, которые должны только-только появиться в поле ближайшей зоны развития личности. При этом в это определение добавляется характеристика неоднозначности итогового результата. Вместе с тем современная практика применения данного понятия предполагает реализацию итогового продукта с качественной детализацией.

Совершенно очевидно, что любая из сфер деятельностей по-своему будет преломлять содержание понятия «проектная деятельность». В этом свете разумно проанализировать позиции о сущности социальной проектной деятельности.

Т.А. Михайлова указывает на социальную значимость реализуемых проектов в рамках осуществления поддержки нуждающихся граждан [5]. При этом в отличие от образовательных проектов социальные проекты носят однозначно прикладной характер. Вместе с тем она предлагает универсальное понятие социально-проектной деятельности - действия, направленные на развитие социально-важных процессов.

Также она указывает, что социально-проектная деятельность делится на четыре подгруппы: культурно-исторические, здоровьесберегающие, 
педагогические и связанные с совершенствованием профессиональной культуры социальных работников [9]. Поскольку предмет исследования формирование педагогической культуры, разумно уточнить конкретные формы последних двух видов деятельности. Также стоит отметить, что в качестве форм будут учитываться виды деятельности из реальной практики социального работника.

\section{Педагогические формы социально-проектной деятельности}

1. Приобщение студентов вузов в качестве ассистентов для практикующих социальных работников. Ассистенты могут привлекаться для проведения обучающих консультаций нуждающихся граждан. К числу вопросов, по которым могут проконсультировать ассистенты, относятся вопросы правовой поддержки. 2. Также будущих социальных работников допустимо привлекать в качестве специалистов группы поддержки практикующих психологов, консультирующих граждан по острым жизненным вопросам.

\section{Формы деятельности, связанные с совершенствованием профессиональной культуры социальных работников}

1. Организация личной исследовательской деятельности в области оказания социальной поддержки нуждающимся гражданам. 2. Участие в курсах, посвящённых вопросам развития профессиональной культуры специалистов по социальной работе. 3. Участие в волонтёрских проектах для накопления знаний в области управления социальными проектами [2].

Поскольку за определение «педагогическая культура» принята версия, сформулированная В.Л. Бениным, все вышеперечисленные формы социально-проектной деятельности позволяют формировать педагогическую культуру [1]. Суть работ В.Л. Бенина заключается в уточнении «педагогической культуры», как интегративного результата педагогического воздействия на личность с различных социальных позиций.

Также следует уточнить иные предложения по формированию педагогической культуры средствами социально-проектной деятельности.

Л.С. Пастухова социально-проектную деятельность в целом относит к воспитательной форме развития педагогической культуры [6]. При этом воспитательная форма воздействия становится возможной только при педагогическом сопровождении студентов, вовлекающихся в реальные социальные программы помощи населению.

Стоит отметить, что обзор источников по исследуемой проблематике раскрыл содержательные линии названия статьи. Также можно однозначно утверждать, что вовлечение будущих специалистов по социальной работе в социально-проектную деятельность является 
условием формирования педагогической культуры. Были выявлены виды социально-проектной деятельности, составляющие базис педагогической культуры: собственно, педагогические и связанные с совершенствованием профессиональной культуры социальных работников. Поскольку исследуемые вопросы имеют отношение к весьма динамичной сфере жизнедеятельности современного социума, разумно указать на необходимость продолжения научных изысканий в этой области.

\section{Список литературы:}

1. Бенин В.Л. Теоретико-методологические основы формирования и развития педагогической культуры : автореферат дис. ... д-ра пед. наук : 13.00.01 / В.Л. Бенин. - Екатеринбург, 1996. - 32 с.

2. Бочарникова Н.А. Формирование профессиональной культуры социального работника в образовательном пространстве университета : автореферат дис. ... канд. пед. наук : 13.00 .08 / Бочарникова Н.А. - Чита, 2012. - 24 с.

3. Горина А.В. Психолого-педагогическое сопровождение формирования профессиональной компетентности студентов в социальной проектной деятельности / А.В. Горина, П.И. Фролова // Вестник Сибирской государственной автомобильно-дорожной академии. - 2014. - №. 5 (39).

4. Ильясов Д.Ф. Развитие представлений о педагогических теориях и подходах к их проектированию / Д.Ф. Ильясов, О.А. Ильясова // Сибирский педагогический журнал. - 2010. - № 1. - С. 39-50.

5. Михайлова Т.А. Проектная деятельность работников социальной сферы / Т.А. Михайлова // Казанский педагогический журнал. - 2015. - №. 5-1.

6. Пастухова Л.С. Социально-проектная деятельность как открытое воспитательное пространство: к созданию современной концепции гражданского воспитания / Л.С. Пастухова // Отечественная и зарубежная педагогика. 2019. - T. 1. - №. 5 (62).

7. Приказ Министерства труда и социальной защиты РФ от 18 июня 2020 г. $\mathrm{N} 351 \mathrm{н}$ «Об утверждении профессионального стандарта "Специалист по социальной работе». - URL: https://base.garant.ru/74386899/ (дата обращения: 27.02.2021).

8. Catellani N. et al. Development of psychological readiness in physical education teachers for the implementation of inclusive education / N. Catellani, D.F. Ilyasov, E.A. Cherepov, A.A. Sevryukova, E.A. Selivanova, V.V. Kudinov, N.O. Nikolov // Человек. Спорт. Медицина. - 2018. - Т. 18. - №. 1. - С. 125-137.

9. Kurbatov V.I., Kurbatova O.V. Social'noe proektirovanie. - Rostov n/D: Feniks, 2001. - S. 27-28. 


\title{
НЕОБХОДИМОСТЬ РАЗВИТИЯ ТЕРМИНОЛОГИЧЕСКОЙ КОМПЕТЕНЦИИ В ПРОЦЕССЕ ОБУЧЕНИЯ АНГЛИЙСКОМУ ЯЗЫКУ СТУДЕНТОВ МЕДИЦИНСКИХ СПЕЦИАЛЬНОСТЕЙ
}

\author{
Киселёва Дарья Олеговна \\ студент, \\ Томский Государственный Педагогический Университет, \\ РФ, г. Томск
}

\begin{abstract}
АННОТАЦИЯ
Согласно современным представлениям об обучении языку, развитие терминологической компетенции у будущих профессионалов играет центральную роль в овладении языком, независимо от того, является ли этот язык первым, вторым или иностранным.
\end{abstract}

Ключевые слова: терминология, английский язык, медицина, терминологическая компетенция.

Согласно современным представлениям об обучении языку, развитие терминологической компетенции у будущих профессионалов играет центральную роль в овладении языком, независимо от того, является ли этот язык первым, вторым или иностранным. В течение последних двадцати лет наблюдается возрождение внимания к изучению лексики на различных уровнях владения языком и в различных контекстах.

Развитие словарного запаса является одной из основных проблемных областей в курсах профессионально-ориентированного обучения английскому языку (ESP), одной из наиболее важных областей компетенции второго языка. Умение генерировать правильную терминологически насыщенную речь, правильно понимать, передавать профессиональные тексты и речь специалистов, профессионально интерпретировать речь иностранных коллег является важной частью учебных планов всех курсов.

Медицинский перевод - один из самых сложных видов переводческих услуг, обусловленный его высоким уровнем сложности и риском возникновения любой ошибки. Это узкоспециализированная сфера переводческой деятельности, из-за чего часто возникает нехватка специалистов в этой области. В настоящее время в английском языке широко используется выражение «английский для медицинских целей» (EMP - English for Medical Purposes).

Студенты, начинающие изучать медицину сквозь призму иностранного языка, нуждаются в помощи в виде прямого обучения с изучением 
специальной лексики, которая является для них совершенно новой. Студенты-медики имеют сильную мотивацию изучать медицинский английский, что влияет на их готовность преуспеть в изучении языка. Они отдают себе отчет в том, что изучаемый ими язык будет полезным инструментом для получения статуса и лучшей работы, что, овладев медицинским языком, они смогут активно участвовать в обмене научными знаниями на международной арене, что является одним из требований для продвижения в их нынешней или будущей работе. Они знают, что чем лучше их медицинский английский, тем легче будет контакт с иностранными пациентами, коллегами и литературой. Студенты и врачи должны овладеть медицинским словарем, который позволит им правильно писать истории болезни, отдавать распоряжения пациентам и медсестрам, обсуждать проблемы с пациентами и персоналом больницы. Они также должны читать научную литературу, выступать с речами и участвовать в дискуссиях на медицинских конференциях.

Студенты-медики должны знать, что означают специальные слова, как они используются и как произносятся. Выбор слов в общении зависит от стиля, используемого в определенном контексте, например, врачи используют разные стили при разговоре с пациентом и при разговоре с членом медицинского персонала (медсестрой или другим врачом). Студенты обычно хотят расширить объем словарного запаса, хранящегося в их памяти, поскольку это лучший показатель их языкового совершенствования.

Научная терминология является высшим проявлением человеческой мысли, главным структурным элементом уточнения и стандартизации языка отдельной отрасли. Термин - это основное лексическое средство, фиксирующее понятие в устной и письменной речи, «слово (или словосочетание) специальной сферы употребления, являющееся наименованием понятия и требующее дефиниции». Он принадлежит к логикопонятийной системе определенной отрасли научного знания и лексической системе общелитературного языка. С помощью терминов в вербальной форме фиксируются результаты процесса познания сущности предметов и явлений объективной действительности и внутренней жизни человека, осуществляется открытие нового научного знания. Они одновременно отражают актуальный уровень развития теории и практики соответствующей отрасли и являются базисом их дальнейшего развития. Именно в данном направлении реализуются такие специфические функции термина, как эвристическая (открытие нового научного знания) и когнитивная (результат процесса познания сущности предметов и явлений объективной действительности и внутренней жизни человека, вербализация специального концепта). 
Студентам медицинских направлений необходимы знания предметной области, навыки поиска информации, анализа, оценки и документирования, чтобы справиться с различными типами терминологических задач. Эти знания и совокупность умений составляют терминологическую компетенцию. Терминологические навыки позволяют студентам понимать основные понятия специализированных текстов, использовать переводческие технологии.

Среди критериев формирования профессионально-терминологической компетенции будущих специалистов можно выделить следующие:

- объем знаний профессиональной терминологии и качество профессиональной речи;

- мотивация в изучении профессиональной терминологии, осознание важности и необходимости ее использования в будущей профессии;

- оперативность в использовании профессиональной терминологии, умение использовать ее при выполнении своих служебных обязанностей;

- профессиональный подход в выборе языковых средств для объяснения процессов и явлений;

- умение использовать профессиональную терминологию в процессе установления коммуникативных отношений и осознание готовности к ее использованию, руководствуясь личностными качествами.

Процесс овладения терминологией имеет свои особенности и сложности. На первых этапах изучения профессионально ориентированных дисциплин у студентов накапливается множество терминов, которые зачастую являются бессистемными и разрозненными. Практический опыт показывает, что только через целенаправленную работу над содержанием понятий студенты могут глубоко запомнить термины. Новые термины вводятся при изучении понятий в процессе преподавания учебного материала, обсуждения или объяснения, демонстрации объектов, лабораторных работ, практических занятий и т. д. Важно, чтобы одни и те же термины использовались в разных учебных ситуациях, проявлялись в непосредственном наблюдении за естественными (или виртуальными) медицинскими операциями.

В процессе самостоятельной работы создаются условия для углубленного овладения студентами профессиональной терминологией. Самостоятельная работа с учебником или словарем позволяет систематизировать терминологические знания и заключается в составлении глоссария по определенной теме или модулю, а также индивидуального терминологического словаря по определенному предмету. Работа со схемами, моделями и манекенами позволяет визуализировать изучаемый материал. Такая самостоятельная работа может выполняться как в 
реальной, так и в виртуальной среде (цифровые фотографии строения человеческого скелета, трехмерные цифровые модели строения органов и систем и др.). Преимущества виртуальных моделей перед плоскими графическими изображениями заключаются в их объемности, расширении сферы их применения на объекты, где важны изучение топографии деталей, их относительного распределения и соподчиненности.

Очевидно, что эффективность формирования профессиональнотерминологической компетентности во многом определяется мотивацией студентов к восприятию и переработке, активному поиску и систематизации, саморазвитию и творческому подходу в овладении профессиональной терминологией.

Терминологическая работа является частью процесса перевода, и без хороших навыков поиска информации студенты не смогут повысить свои знания и, следовательно, производить качественные переводы. Деятельность, связанная с терминологией, обычно воспринимается как утомительная и отнимающая много времени, и студенты склонны пренебрегать этой фазой процесса перевода. Они обычно проверяют терминологию во время перевода и редко записывают результаты своих поисков. Во время изучения иностранного языка студенты должны быть осведомлены о важности правильного управления терминологией. Это может быть сделано с помощью соответствующих упражнений, в которых студенты учатся правильно использовать словари, работать с ИКТ, чтобы облегчить их переводческую работу. В процессе своего обучения студенты должны иметь возможность ознакомиться с источниками специальных знаний и приобрести навыки, которые позволят им эффективно использовать эти ресурсы и инструменты. Таким образом, они смогут развивать свои специализированные знания и расти профессионально как будущие специалисты.

\section{Список литературы:}

1. Бордовская Н.В., Кошкина Е.А. Структурно-функциональная модель терминологической компетентности специалиста // Вестник СПбГУ. Серия 16: Психология. Педагогика. 2016. №4. URL: https://cyberleninka.ru/article/n/strukturno-funktsionalnaya-modelterminologicheskoy-kompetentnosti-spetsialista (дата обращения: 28.11.2020).

2. Даниленко В.П. Лексика языка науки. Терминология: автореф. дис... д-ра филол. наук. М., 1977. 41 с.

3. Коляда С.В. Коммуникативная компетенция руководителя// Бизнес Ключ. - №10. - 2007. [Электронный ресурс]. URL: http://www.bkworld.ru/archive/y2007/n10-2007/n-10-2007_241.html (дата обращения: 14.11.2020). 
4. Лукашенко А.М. Профессиональные компетенции руководителя / Современная конкуренция. - №6. - 2009.

5. Iwona Sikora. Developing terminological competence in a specialized translation classroom - problems, resources, and tools // Technical University of Częstochowa. 2017. P 19.

6. M.T. Cabré. Terminology and translation // Y. Gambier and L. van Doorslaer. Handbook of Translation Studies: Volume. 2010. P. 359.

\section{ПЕДАГОГИЧЕСКОЕ РУКОВОДСТВО САМОСОВЕРШЕНСТВОВАНИЕМ ОФИЦЕРОВ КАК ОДНО ИЗ УСЛОВИЙ ЭФФЕКТИВНОЙ ДЕЯТЕЛЬНОСТИ КОМАНДИРА}

Краснова Марина Васильевна

канд. пед. наук, ст. науч. сотр. Военной академии ракетных войск стратегического назначения, РФ, Московская обл., г. Балашиха

Проняева Елена Вячеславовна науч. сотр. Военной академии ракетных войск стратегического назначения, РФ, Московская обл., г. Балашиха

В продолжение темы о профессиональном самосовершенствовании офицера (сборник статей по материалам XLIII MHПК № 1 (43), представляется актуальным рассмотрение вопроса о педагогически обоснованном руководстве этим процессом, которое предполагает понимание командиром того, что принципиальным условием самосовершенствования является включение офицером в понятие «успешный результат» не только достижения нормативных, предписанных различными документами показателей и стандартов внешних параметров деятельности, но и уровня задействования и развития при этом профессионально-значимых качеств, знаний, умений и навыков собственной личности.

Целевые психолого-педагогические исследования в области деятельности офицеров по самосовершенствованию показывают, что в ходе этой работы они испытывают определенные трудности. Среди них прежде всего выделяются: 
- слабое владение навыками самооценки;

- трудности в определении целей и задач самосовершенствования;

- не всегда правильное и рациональное планирование работы над собой;

- слабое владение методикой самосовершенствования.

Необходимо отметить и тот факт, что офицеры по-разному относятся к своему самосовершенствованию, а, следовательно, по-разному занимаются им. Условно можно выделить три группы офицеров с различными уровнями отношения к самосовершенствованию (см. табл. 1).

Высокий - характеризуется ярко выраженной потребностью к самосовершенствованию, установкой на всесторонне развитие своей личности. При этом побудительным фактором к самосовершенствованию становится не прямое внешнее требование (команда, приказ) и не нуждастимул, а личная инициатива офицера.

Средний - процесс самосовершенствования идет не систематически, так как «источник» его находится не в самой личности офицера, а в окружающих условиях, стимулах. Отсюда и некоторая «вынужденность» в характере работы над собой, осознание необходимости развивать профессионально-важные качества. Способ реализации этой активности добровольная, сознательная саморегуляция своего поведения.

Низкий - проявляется негативное отношение к самосовершенствованию, к оценке его необходимости в профессиональной деятельности. Побудительными стимулами являются, как правило, лишь жесткие требования и регулярный контроль со стороны командиров, товарищей по службе.

Таблица 1.

Характеристика активности офицеров в самосовершенствовании

\begin{tabular}{|c|c|c|c|}
\hline Уровень активности в & \multicolumn{3}{|c|}{ Возраст офицера } \\
\cline { 2 - 4 } самосовершенствовании & $\mathbf{2 5 - 3 0}$ лет & $\mathbf{2 5 - 3 5}$ лет & $\begin{array}{c}\text { свыше 35 } \\
\text { лет }\end{array}$ \\
\hline Высокий & & & $7 \%$ \\
Средний & $12 \%$ & $9 \%$ & $71 \%$ \\
Низкий & $55 \%$ & $66 \%$ & $22 \%$ \\
\hline
\end{tabular}

Анализ данных таблицы свидетельствует о том, что в отношении офицеров к самосовершенствованию преобладает средний уровень. Вместе с тем, довольно большое количество офицеров характеризует низкий уровень, особенно среди молодых офицеров. К сожалению, прохождение службы офицерским составом не способствует развитию высокой мотивации профессионального самосовершенствования. Налицо 
и такая отрицательная тенденция, как снижение числа офицеров с высоким уровнем самосовершенствования с увеличением выслуги лет. И если учесть, что показатели среднего уровня, характерного для большинства офицеров, также не вполне удовлетворяют предъявленным требованиям, то закономерен вывод для командиров-руководителей о необходимости существенного улучшения качества педагогического руководства самосовершенствованием офицеров.

В чем суть руководства офицеров работой над собой? Это сложный, многогранный процесс, представляющий собой систему учебных, воспитательных организационных мероприятий, направленных на обеспечение целеустремленной, систематической и разносторонней работы по совершенствованию своей личности. Вместе с тем, это тонкое, деликатное дело. Оно требует от командиров большого такта, высокой общей и военно-педагогической культуры, подлинной требовательности и заботы о людях. Ведущая роль в руководстве самосовершенствованием офицеров принадлежит командиру и его заместителю по военно-политической работе, которую они осуществляют с опорой на офицерские коллективы частей и подразделений.

Основная задача руководства этим процессом состоит в целенаправленном побуждении офицеров к активной работе над собой, в выработке у них соответствующих мотивационных установок на разностороннее самосовершенствование, в создании для этого необходимых условий. Само руководство носит творческий характер и зависит от многих объективных и субъективных факторов. Вместе с тем, в организации и осуществлении руководства командирам необходимо учитывать общие научно-обоснованные закономерности и тенденции. Поэтому, опираясь на данные психолого-педагогических наук и на практический опыта армейской жизни, в качестве основных направлений в качестве руководства самосовершенствованием офицеров в частях и подразделениях можно выделить:

- постоянное изучение офицеров и опыта их работы над собой;

- всестороннее разъяснение требований, предъявляемых к офицерам в современных условиях;

- разъяснение сущности, значения профессионального самосовершенствования и постановка конкретных задач по самовоспитанию и самообразованию офицеров;

- ознакомление офицеров с эффективными методами и приемами работы над собой и основными направлениями ее научной организации;

- формирование положительного общественного мнения, всестороннее стимулирование самовоспитательной работы офицерского состава частей и подразделений; 
- обеспечение личного примера в развитии своей личности самих офицеров-руководителей;

- контроль и помощь в работе над собой;

- включение офицеров в активные и разнообразные виды деятельности;

- создание офицерам необходимых условий для систематической и целенаправленной работы над собой [4.С.2550].

Остановимся на некоторых моментах руководства самосовершенствованием офицеров, которые влияют на степень функционирования конкретных психолого-педагогических механизмов развития личности и поэтому обладают, на наш взгляд, определенным воздействием на весь процесс самосовершенствования.

Командиру важно понять, что тактика его работы по всем вышеперечисленным направлениям должна преследовать следующие цели: актуализировать в деятельности офицеров основные мотивационные противоречия самосовершенствования; создать оптимальные условия для их разрешения в оптимальные разрешения в необходимых для военно-профессиональной деятельности побуждениях офицеров; поддерживать условия устойчивого функционирования этих побуждений. Как видим, она основывается на понимании процесса самосовершенствования как неразрывного единства внешних воздействий и внутренних условий.

Что касается внутренних условий самосовершенствования, то командиру-руководителю важно обратить внимание на два определяющих момента: формирование устойчивой положительной мотивации профессионального самосовершенствования у офицеров и ликвидации у них когнитивных ограничений в процессе работы над собой.

Формируя и развивая предпосылки эффективного самосовершенствования у офицеров (мотивация, компетентность и др.), командиры обязаны не упускать из виду и не менее важный момент: создавать такие «внешние» условия повседневной военно-профессиональной деятельности, которые бы соответствовали успешному и результативному процессу самосовершенствования и тем самым вольно или невольно стимулировали офицеров к более активной работе над собой.

Цель руководства самосовершенствованием в этом плане состоит в актуализации у офицеров мотивов в самосовершенствовании непосредственно с помощью моделирования конкретных ситуаций учебнобоевой и служебной деятельности и целенаправленных корректирующих воздействий со стороны командиров и начальников.

На представленной схеме (рисунок 1) достаточно обстоятельно представлены общие закономерности и тенденции оптимизации процесса самосовершенствования целенаправленным моделированием внешних 
факторов с опорой на рекомендации психологической науки и, на наш взгляд, представляющие интерес для офицера-руководителя.

\section{Система руководства процессом профессионального самосовершенствования}



\section{Рисунок 1. Система руководства процессом профессионального самосовериенствования}

Как видно из этой схемы, искусство управленческой деятельности командира состоит в умении создать ситуации самосовершенствования в процессе служебной деятельности и в способности включить в них офицерский состав.

Таким образом, одним из основных путей руководства самосовершенствованием является целенаправленное моделирование и развитие ситуаций, при которых офицеры постоянно сталкиваются с необходимостью постоянно активно расширять и применять имеющиеся знания, умения, навыки, ставятся в условия, требующие от них проявления формируемых профессионально-значимых качеств. Систематичность и регулярность действий в подобных ситуациях будет способствовать развитию личности офицера.

\section{Список литературы:}

1. Калита А.Б. Офицер - воспитатель подчиненных // Ориентир. - 2000. - № 5.

2. Куликова Л.Н. Проблемы саморазвития личности. - Хабаровск, 1997.

3. Королев Л.М. Психологическое обеспечение профессионального становления военного специалиста: Монография/Л.М. Королев. - М.: Издательско-торговая корпорация «Дашков и К», 2020. - 204 с.

4. Сережникова Р.К., Маргарьян А.Ю. О методической готовности будущих офицеров к организации самообразования военнослужащих // Профессиональное образование в современном мире.2019. Т.9 № 1. С. 2549-2558. 


\title{
ПРОБЛЕМЫ ОРГАНИЗАЦИИ ИНДИВИДУАЛЬНЫХ РАБОТ СТУДЕНТОВ ПО МАТЕМАТИКЕ
}

\author{
Нишонов Фарход Мусажонович \\ преподаватель математики, \\ Академический лицей \\ Ферганского политехнического института, \\ Республика Узбекистан, г. Фергана
}

\begin{abstract}
АННОТАЦИЯ
Современный этап строительства и реформирования высшей школы в Узбекистане предъявляет качественно новые требования к организации, содержанию и методике процесса обучения в высших учебных заведениях, его индивидуализации и дифференциации. Проведенный анализ выявил, что перед методикой обучения математике встала задача совершенствования теории и практики подготовки специалиста, соответствующего всему комплексу современных требований.
\end{abstract}

Ключевые слова: математика, методика обучения, качество знаний, умения, обучение, инновационные технологии.

В последние годы интенсивно развиваются новые подходы и математические методы, основанные на теории вероятностей и математической статистике. Это разработка математического аппарата таких прикладных дисциплин, как надежность и ремонт машин, обслуживание техники, сбор, учет обработка и статистический анализ данных, характеризующих процесс функционирования реальных систем техники с целью разработки мероприятий по повышению их эффективности и качества работы. Применение заданий с инженерно-техническим содержанием при проведении занятий на инженерных специальностях способствует повышению уровня усвоения материала, повышению интереса к изучению данного предмета. Знания по математическим дисциплинам будут сознательнее и прочнее усваиваться студентами, если в процессе обучения применять задачи с профессионально направленным содержанием. Проведенное исследование свидетельствует, что к началу XXI века система обучения студентов университетов Узбекистана поэтапно входит в кредитную форму подготовки, которая требует нового подхода к подготовке студентов. Это особенно важно, когда самостоятельная деятельность и в связи с этим, индивидуализация обучения студентов имеют первостепенное значение. В связи с этим, перед методикой обучения математике встала задача совершенствования теории и практики 
подготовки специалиста, соответствующего всему комплексу современных требований.

При использовании понятия «индивидуализация обучения» или «дифференциация обучения» необходимо иметь в виду, что при его практическом использовании речь идет не об абсолютной, а об относительной индивидуализации. В высшей школе, на практике индивидуализация всегда относительна по следующим причинам: 1) обычно учитываются индивидуальные особенности не каждого отдельного студента, а группы студентов, обладающих примерно сходными особенностями; 2) учитываются лишь известные особенности, или их комплексы и именно такие, которые важны с точки зрения учения; наряду с этим может выступать ряд особенностей, учет которых в конкретной форме индивидуализации невозможен, или даже, не так уж и необходим; 3) иногда происходит учет некоторых свойств или состояний лишь, в том случае, если именно это важно для данного студента (например, талантливость в какой-либо области, расстройство здоровья); 4) индивидуализация реализуется не во всем объеме учебной деятельности, а эпизодически или в каком-либо виде учебной работы и интегрирована с не индивидуализированной работой.

В контексте индивидуализации обучения понятие «дифференциация〉 исходит из особенностей индивида, его личностных качеств. Однако необходимо иметь в виду, что понятие «дифференциация» используется и в более широком значении: при формировании содержания образования и организации учебной работы мы сталкиваемся с дифференциацией по возрастному, половому, регионально-экономическому, национальному и другим признакам. Попытаемся еще уточнить, как мы характеризуем понятие «индивидуальный подход» и понятие «дифференциация». В первом случае мы имеем дело с принципом обучения, во втором - с осуществлением этого принципа, которое имеет свои формы и методы. В этом же значении представляется соотношение принципа индивидуального подхода и индивидуализации обучения. Этот принцип также наиболее широко рассмотрен в работе. При использовании нами понятия «индивидуализация обучения» или дифференциация обучения» необходимо иметь в виду, что при его практическом использовании речь идет не об абсолютной, а об относительной индивидуализации.

Одним из основных факторов, которые влияет на профессионализм в будущем, является целенаправленное качественное образование.

Определенное значение зависит от того в каком значении используется термин «самостоятельный». В основном выделяют 3 значения данного слова: 
- студент должен выполнять работу сам, без непосредственного участия педагога;

- от студентов требуются самостоятельные мыслительные операции, самостоятельное ориентирование в учебном материале;

- выполнение работы строго не регламентировано, студенту предоставляется свобода выбора содержания и способов выполнения задания.

Самостоятельная работа в высшей школе является специфическим средством организации и управления самостоятельной деятельностью студентов в учебном процессе, средством самоорганизации и самодисциплины студентов при овладении необходимыми знаниями, умениями и навыками. Как известно, при кредитной технологии обучения сокращение объема аудиторной работы непосредственно повышает значение и статус самостоятельной работы студента. Для правильной и эффективной организации СРС, по нашему мнению, большое значение имеют следующие условия: подготовленность преподавателей к эффективной организации самостоятельной работы по кредитной системе обучения; наличие учебно-методического комплекса по каждой дисциплине, включающий описание курса в печатном и электронном виде, форм и средств контроля уровня самостоятельного освоения студентом СРС с указанием содержания и сроков их проведения, справочника-путеводителя для студента на весь период обучения; обеспеченность компьютерной и телекоммуникационной техникой; индивидуализация заданий, а также учет уровня подготовленности и склонности каждого студента; применение инновационных технологий; оптимальная нагрузка студентов в области самостоятельной работы.

Как показывает практика, в большинстве университетах существуют две формы самостоятельной работы:

- традиционная, т.е. собственно самостоятельная работа студентов, выполняемая самостоятельно в произвольном режиме и времени, в удобные для студента часы, часто вне аудитории.

- аудиторная самостоятельная работа под контролем преподавателя, у которого в ходе выполнения задания можно получить консультацию.

В Ферганском политехническом институте приняты несколько видов самостоятельной работы: регулярные и долгосрочные. Регулярные самостоятельные работы выполняются студентами в соответствии с предложенными в силлабусе заданиями к каждому занятию. Их выполнение контролируется и оценивается преподавателем на консультационных занятиях. Как показывает опыт ведущих специалистов в области преподавания математики, а также опыт преподавателей 
кафедры, наиболее эффективными формами и видами регулярной самостоятельной работы студентов являются следующие: выполнение индивидуальных задач с тремя уровнями сложности, доказательство теорем и формул, написание докладов и рефератов, ответ на теоретические вопросы и т. д. Индивидуализация подготовки студентов при кредитной форме обучения не исключает, а предполагает также коллективные, фронтальные и групповые формы деятельности, усиление в обучении связей «преподаватель-студент» и «студент-студент», при этом большой акцент делается на самостоятельность в познавательной деятельности студентов.

В заключении необходимо отметить, что индивидуализация обучения в высшей школе при кредитной подготовке состоит в том, чтобы увидеть особенности психофизиологического развития студентов и строить учебный процесс, исходя из их возможностей и способностей. В нашем примере, раскрытие и совершенствование индивидуальности студентов происходит в процессе овладения знаниями основ высшей математики в университете, поэтому индивидуализация обучения не освобождает студентов от учебных заданий, которые им трудно даются. Задача индивидуализации заключается в том, чтобы дать всем студентам систему математических знаний как средство их развития и компетентности. Решение вопроса об индивидуализации процесса подготовки студентов нельзя понимать посредством сокращения учебного материала или решения математических задач для одних студентов и видоизменения её для других.

\section{Список литературы:}

1. Marginson S. World higher education under conditions of national/global disequilibria //Centre for Global Higher Education, UCL Institute of Education, London. -2018.

2. Nishonov F.M., Azizov E. Matematik matnlar tarjimasidagi o'ziga hos jihatlar va muammolar. //«Адабий алоқалар ва маданиятларнинг ўзаро таъсири» номли Халқаро илмий-анжуман мақолалар тўплами. 2-Қисм. 2019 й. C. 166-168.

3. Nishonov F.M., Qo'shnazarova M. Maktab yoshigacha bo'lgan bolalarda matematik tasavvurlarni shakllanishida didaktik o'yinlarning o'rni// Maktabgacha ta' lim taraqqijotining dolzarb masalalari. FarDU. - 2019. 166-167.

4. Nishonov F.M., Ehsonova N.T., \& Tolibov I.S. (2019). Professional growth of the teacher of mathematics of the academic lyceum in the conditions of technologies of the digital educational space. ISJ Theoretical \& Applied Science, 03 (71), 534-537.

5. Nishonov F.M, Kurpayanidi K.I. (2018). Some questions of design of tasks in mathematics. ISJ Theoretical \& Applied Science, 09 (65): 41-44. 
6. Trautwein C., Bosse E. The first year in higher education-critical requirements from the student perspective //Higher education. - 2017. - Т. 73. - №. 3. - С. 371-387.

7. Курпаяниди К.И. Вопросы совершенствования методики преподавания бизнес-дисциплин //Психология. Социология. Педагогика. - 2013. - №. 10. C. 03-07.

8. Курпаяниди К.И. Дорожная карта совершенствования организации учебного процесса в системе высшего образования //Международный журнал прикладных и фундаментальных исследований. - 2016. - №. 11-5. - С. 955958.

9. Курпаяниди К.И. Некоторые вопросы совершенствования методики преподавания бизнес дисциплин в высшем образовательном учреждении // Гуманитарные научные исследования. - 2013. - №. 11. - С. 15-15.

10. Курпаяниди К.И., Нишонов Ф.М. Конструирование систем задач по математике //Международный журнал гуманитарных и естественных наук. - 2018. - №. 10-1.

11. Курпаяниди К., Маматова 3.М., Толибов И.Ш. К вопросу о научном подходе к построению аутсорсинговой бизнес-модели современной предпринимательской структуры // Достижения науки и образования. 2019. №7 (48).

12. Нишонов Ф. Дифференциал тенгламаларнинг тебранмас ва тебранувчи ечимлари/Материалы конференции: Иқтисодий ресурслардан фойдаланиш самарадорлигини ошириш йўналишлари. Илмий-амалий анжуман материаллари. Фарғона политехника институти, 2015.

13. Нишонов Ф.М., Эхсонова Н.Т., Толибов И.Ш. У. Некоторые вопросы профессионального роста преподавателя математики в условиях цифровой экономики //Проблемы современной науки и образования. - 2019. №. 4 (137).

14. Нишонов Ф.М.Некоторые вопросы методики преподавания математики в общеобразовательной школе и высшем образовательном учреждении// Материалы конференции «Хозирги замон аниқ ва техник фанлар муаммолари ва уларнинг ечимлари» мавзусидаги Республика илмий-назарий ва амалий анжуман материаллари. I Бўлим. Ажиниёз номидаги Нукус давлат педагогика институти, Нукус, 2018. С. 120-122. 


\title{
ОСОБЕННОСТИ И СПЕЦИФИКА ПРОФЕССИОНАЛЬНОГО РОСТА ПРЕПОДАВАТЕЛЕЙ СИСТЕМЫ СРЕДНЕГО ПРОФЕССИОНАЛЬНОГО ОБРАЗОВАНИЯ
}

\author{
Узунова Галина Петровна \\ директор, \\ АНО «ПОО» «Открытый Таврический колледж», \\ $Р \Phi$, г. Симферополь
}

\section{FEATURES AND SPECIFICITY OF PROFESSIONAL GROWTH OF TEACHERS OF THE SECONDARY PROFESSIONAL EDUCATION SYSTEM}

\author{
Galina Uzunova \\ Director, \\ $A N O$ «POO» «Open Tavrida College», \\ Russia, Simferopol
}

\begin{abstract}
АННОТАЦИЯ
В статье рассматривается вопрос о специфике профессионального роста преподавателей колледжа. Анализируются представления педагогов об их профессиональном развитии, профессиональной карьере, мотивы их профессиональной деятельности. На основании проведенного анализа делается вывод о том, что организация в колледже помощи преподавателям в их профессиональном росте должна осуществляться на основе индивидуально-дифференцированного подхода, позволяющего каждому педагогу спроектировать индивидуальную траекторию своего профессионального развития.

\section{ABSTRACT}

The article discusses the issue of the specifics of professional growth of college teachers. The ideas of teachers about their professional development, professional career, the motives of their professional activity are analyzed. Based on the analysis, it is concluded that the organization of assistance to teachers in their professional growth in the college should be carried out on the basis of an individually differentiated approach that allows each teacher to design an individual trajectory of their professional development.
\end{abstract}


Ключевые слова: профессиональный рост, профессиональное развитие, индивидуальная траектория, индивидуально-дифференцированный подход.

Keywords: professional growth, professional development, individual trajectory, individually differentiated approach.

В настоящее время, в условиях реформирования системы профессионального образования, актуализируются вопросы повышения профессионального мастерства педагогов, осуществляющих свою деятельность в образовательных организациях среднего профессионального образования [4].

Актуальность данной проблемы обусловлена тем, что преподавателями колледжей зачастую становятся не квалифицированные педагоги, имеющие базовое педагогическое образование, а профильные специалисты, имеющие соответствующую профессиональную подготовку и определенный стаж профессиональной деятельности, никак не связанной с педагогической деятельностью. Отсутствие базового педагогического образования обусловливает самостоятельный поиск преподавателем колледжа методов и приемов осуществления своей педагогической деятельности. Такой поиск может быть основан на личном опыте педагога, на его трансляции в своей педагогической деятельности [3].

Однако реформирование системы образования в России обусловило пересмотр роли и функций современного педагога, трансформацию требований, предъявляемых к качеству его профессиональной деятельности и к его профессиональному росту [2]. Трансляция прошлого опыта, как и вооружение преподавателей определенным комплексом педагогических знаний и умений не могут гарантировать достижение ожидаемого эффекта. Здесь необходима новая система повышения его квалификации, позволяющая проектировать индивидуальную траекторию его профессионального роста [1].

С целью выявления особенностей и специфики профессионального роста преподавателей колледжа было проведено исследование, ориентированное на выявление мотивов и целей прохождения преподавателями курсов повышения квалификации.

В исследовании, проведенном методом опроса, приняли участие 214 преподавателей, работающих в колледжах разной направленности. Среди респондентов-преподавателей высшее педагогическое образование имели $70 \%$, и $30 \%$ имели другое базовое образование.

На вопрос о том, что привлекательного видят преподаватели в своей профессии, большинство отметили, что работа педагогом предполагает неполный рабочий день, большой отпуск, неплохую в среднем зарплату (Рис. 1). 


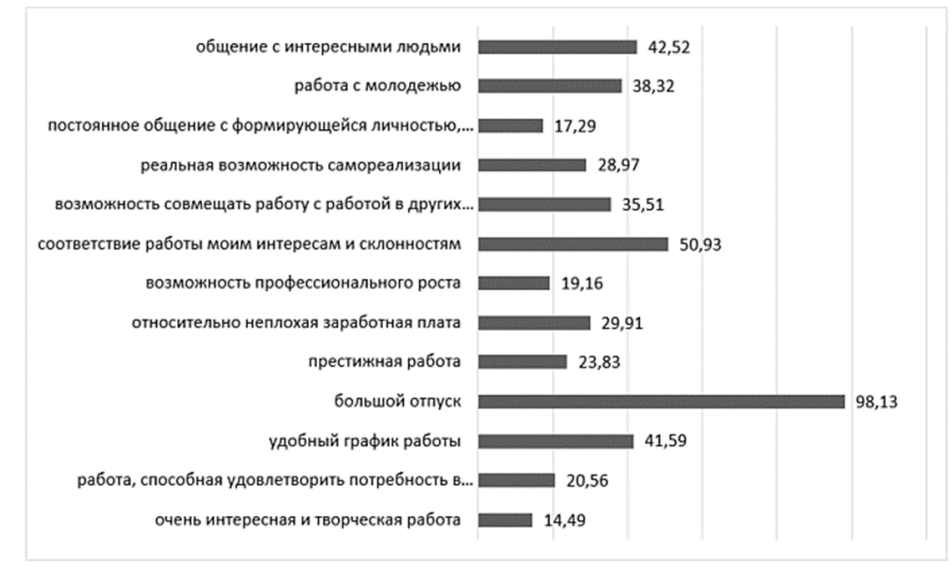

\section{Рисунок 1. Распределение ответов преподавателей колледжа на вопрос о привлекательности для них профессии педагога (\%)}

Отметим, что преподаватели могли выбрать разные варианты ответов без ограничений. В связи с этим, результаты анализа ответов преподавателей позволяют нам прийти к заключению о том, что выбор педагогической деятельности и профессии педагога для большинства из них никак не связан с самой спецификой деятельности. В большинстве случаев мотивами профессионального выбора служили стремление «устроиться», иметь работу, получать материальное вознаграждение, но никак не потребность в профессиональном росте и самореализации личности в выбранной сфере профессиональной деятельности.

Многих преподавателей привлекает в профессии педагога удобный график работы, возможность совмещать работу в колледже с работой в других образовательных организациях, то есть условия трудовой деятельности.

Лишь небольшое количество преподавателей (29\%) отметили, что педагогическая деятельность дает им возможность реализовать свои интересы и склонности, возможности и таланты. Только около $20 \%$ опрошенных преподавателей привлекает работа с молодежью и с формирующейся личностью.

Таким образом, результаты опроса свидетельствуют о недостаточно развитой мотивации преподавателей современных колледжей к своему профессиональному развитию и профессиональному росту.

Данный вывод подтверждается и результатами анализа ответов преподавателей на вопросы об их отношении к курсам повышения квалификации. 
Следует уточнить, что абсолютно все преподаватели, принявшие участие в нашем исследовании, периодически проходят курсы повышения квалификации. При этом, их мнение о пользе таких курсов отнюдь не однозначно.

Так, более половины опрошенных преподавателей колледжей считают курсы повышения квалификации пустой тратой времени (Рис. 2).

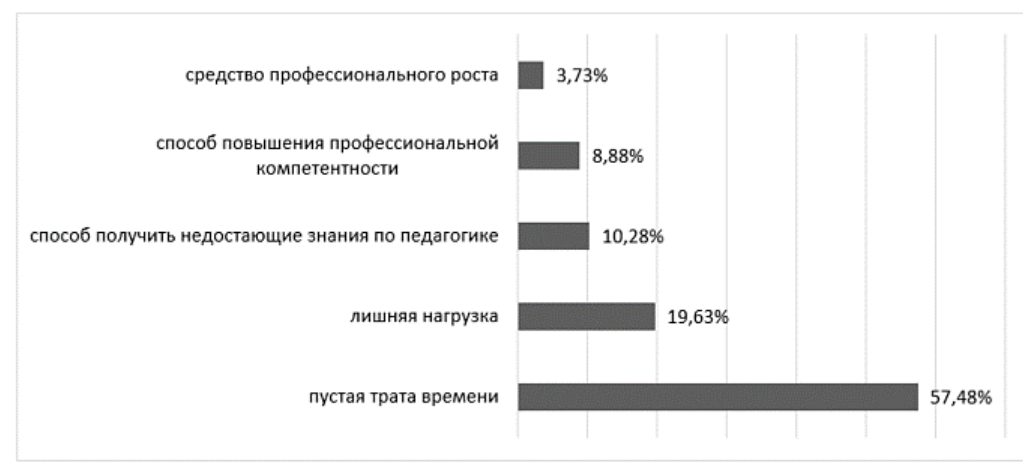

\section{Рисунок 2. Ответы преподавателей колледжа на вопрос: "Чем лично для Вас являются курсы повышения квалификации?» (\%)}

19,63\% преподавателей считают, что курсы повышения квалификации добавляют только лишнюю нагрузку на педагога.

Всего 10\% преподавателей отметили, что курсы повышения квалификации позволяют восполнить недостающие педагогические знания, и 9\% - что они позволяют повысить профессиональную компетентность. И лишь 8 преподавателей, что составляет 3,73\% от общего их количества, принявших участие в нашем исследовании, отметили, что курсы повышения квалификации являются одной из форм их профессионального роста.

В процессе опроса преподавателей было выявлены особенности их представлений о своем профессиональном росте.

Для многих из них профессиональный рост заключается в совершенствовании своего профессионального труда, причем, не педагогического, а труда в области экономики, юриспруденции, инженерной деятельности, то есть совершенствование в предметной деятельности (Рис. 3). 


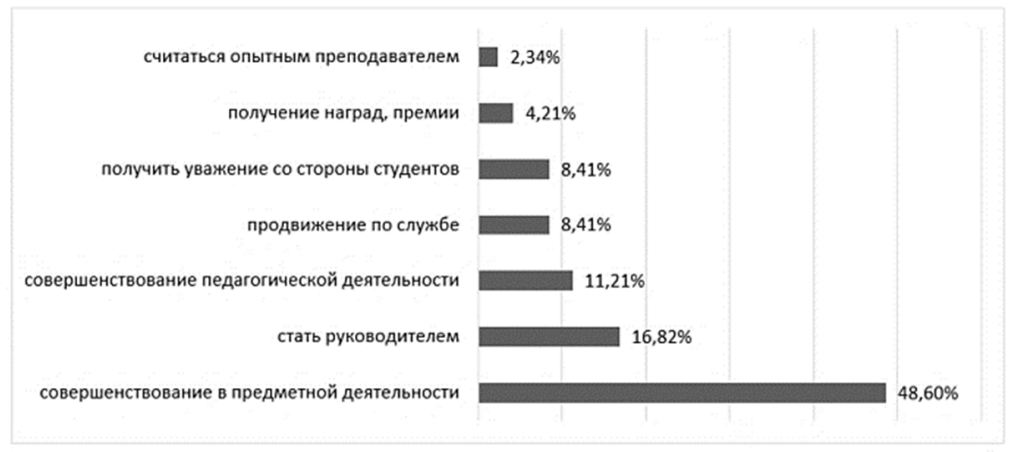

\section{Рисунок 3. Ответы преподавателей колледжа на вопрос: «В чем лично для Вас состоит Ваш профессиональный рост?» (\%)}

Восприятие же профессионального роста как совершенствование педагогического труда характерно для $16,82 \%$ опрошенных преподавателей.

Таким образом, результаты проведенного исследования позволяют прийти к заключению о том, что современным преподавателям системы среднего профессионального образования необходимо повышение мотивированности труда, оказание помощи в осознании ими важности и значимости их педагогической деятельности, в развитии педагогической направленности их личности. Решение таких задач может взять на себя система дополнительного профессионального образования педагогов. Освоение программ повышения квалификации должно быть ориентировано на развитие стремления педагогов к профессиональной педагогической компетентности, а не просто на восполнение их пробелов в педагогической грамотности.

\section{Список литературы:}

1. Воронцова В.Г. Гуманитарные аксиологические основы постдипломного образования взрослых / В.Г. Воронцова. - СПб., 1997. - 247 с.

2. Гарифуллина Р.Р. Проектирование и реализация индивидуальных образовательных маршрутов развития научно-методической компетентности преподавателя вуза в условиях образовательного кластера / Р.Р. Гарифуллина // Казанский педагогический журнал. - 2016. - № 4 (117). - С. 66 -71.

3. Громкова М.Т. Анлрогогическая модель целостного образовательного процесса: монография / М.Т. Громкова. М.: ЮНТЬТ-ДАНА: Закон и право, 2006. - 278 с.

4. Корнеев Ю.В. Развитие профессиональной компетентности педагогов учреждений среднего профессионального образования: автореф. дисс....канд.пед.наук. - М., 2008. 


\title{
ПСИХОЛОГИЯ
}

\author{
СЕКЦИЯ 5.
}

\section{СОЦИАЛЬНАЯ ПСИХОЛОГИЯ}

\section{ПСИХОЛОГИЧЕСКИЕ УСЛОВИЯ УСПЕШНОЙ АДАПТАЦИИ ПОДРОСТКОВ-МИГРАНТОВ}

\author{
Родин Фаина \\ специалист по работе \\ с русскоязычными подростками -мигрантами, \\ Израиль, Ришон Ле Цион
}

Следствием глобализации как процесса культурной, научной, технической унификации (приведения к единому стандарту, форме) и интеграции (установлению взаимосвязей между отдельными, уникальными, самостоятельными социальными объектами и явлениями) стали размытые границы и почти не существующие расстояния. Феномен глобализации породил огромную армию переселенцев, движимых различной мотивацией. Принято выделять две основные формы миграций:

- внутренние миграции - перемещение населения внутри страны из сел в города, из городов в села, из одного региона в другой

- внешние миграции - перемещение населения из одной страны в другую. Эмиграция - это выезд из страны. Иммиграция - въезд в страну.

Причин миграций довольно много. Главной причиной миграций являются экономические условия. При этом принято различать два вида миграций, имеющих экономические причины:

- переселенческие миграции, связанные с освоением новых земель;

- трудовые миграции, связанные с заключением трудовых контрактов.

Другими, не менее важными причинами миграций, являются политические условия. Помимо названных, миграции населения могут быть вызваны национальными, религиозными, экологическими и другими причинами. 
Автор данной статьи, испытав на себе и членах своей семьи трудности адаптации в принимающей стране, и работая более 30 лет с русскоязычными подростками-мигрантами в Израиле, заинтересован в анализе, систематизации как теоретического, так и практического материала по проблеме адаптации подростков из семей мигрантов и на этой основе на создании психологических предпосылок, позволяющих избежать трудностей приспособления в принимающей стране.

Что же происходит с подростками-мигрантами? Проиллюстрируем проблемы адаптации подростков-мигрантов некоторыми данными статистики системы образования Израиля.

Число иммигрантов из бывшего Советского Союза, начиная с 1990-х годов, достигло более одного миллиона человек и составило к текущему моменту более $13 \%$ населения Израиля. Из них около 295000 - детей и подростков, а это около $11,1 \%$ всех детей в стране. Многие из семей мигрантов находятся в сложном социо-экономическом положении, что является предпосылкой для ухода подростков из учебно-образовательных заведений.

Мигранты школьного возраста, прибывшие в Израиль с территорий бывшего Советского Союза, составляют около 17,5\% всех учащихся седьмых- двенадцатых классов, а среди бросивших школу они составляют $28 \%$. 46\% молодёжи, иммигрировавшей в Израиль за последние пять лет, не закончили полного курса обучения и не получили аттестат зрелости. Около $25 \%$, то есть каждый четвертый учащийся-иммигрант, бросили школу (для сравнения, среди их сверстников местного населения страны каждый десятый).

Поскольку перед автором стала задача анализа условий аккультурации и адаптации мигрантов-подростков, то мы обратились к исследованиям Джона Берри в области кросс-культурной психологии в современных поликультурных обществах, а именно - к его классификации успешности адаптации мигрантов в принимающей стране. Анализ проблемы указывает на низкий уровень социальной адаптации молодых иммигрантов, их низкую академическую успеваемость и, как следствие, снижение самооценки, ведущей к уходу из образовательного поля. Подростки часто испытывают дискриминацию, в связи с чем могут настроиться против принимающего общества и представлять для последнего опасность.

Согласно разработанной Дж. Берри теории, процесс вхождения в новую культуру связан с двумя аспектами:

- признание важности сохранения культурной идентичности;

- участие в межкультурных контактах. 
Комбинации этих проявлений определяет одну из четырех возможных стратегий аккультурации: ассимиляция, сепарация, маргинализация и интеграция.

Ассимилящия - аккультурация, связанная с полной идентификацией себя с новой культурой и отрицанием культуры этнического меньшинства, к которому принадлежит субъект. Дж. Берри называет ассимиляцию в доминирующей среде стратегией «плавильного котла».

Сепарация связана с отрицанием представителем этнического меньшинства культуры большинства и сохранением своих этнических особенностей. Сепарация порождает сегрегацию в отношениях с доминирующей группой и ведет к осложнениям в процессе адаптации.

Маргинализация - стратегия поведения мигранта, который не идентифицирует себя ни с культурой этнического большинства, ни с культурой этнического меньшинства, результатом чего является этнокультурная изоляция. Маргинализация обрекает субъекта на отчуждение, потерю идентичности.

Интегращия как стратегия характеризуется идентификацией как со старой, так и с новой культурами, и является идеальной моделью успешной адаптации подростков-мигрантов к условиям принимающей страны. Интеграция обеспечивает мультикультурализм. Согласно исследованиям, только интеграция может быть осознанно выбранной и успешной стратегией аккультурации у групп этнических меньшинств, что становится предпосылкой открытости и принятия по отношению к культурным различиям.

Дж. Берри осуществил сравнительное исследование этнокультурных молодежных средах (International Comparative study of Ethnocultural Youth) в 5 странах, традиционно принимающих много иммигрантов (США, Канада, Новая Зеландия, Австралия и Израиль) и 8 странах, с недавнего времени принимающих много иммигрантов (Франция, Германия, Нидерланды, Норвегия, Португалия, Швеция, Великобритания, Финляндия). Исследуемая рабочая группа составила 5366 подростков-иммигрантов и 2631 подростков из принимающего населения (в возрасте от 13 до 18 лет), а также 2302 родителя-иммигранта и 863 родителя из принимающего населения. Выяснилось, что модель интеграции выбрали $36.4 \%$, сепарации - 22,5\%, ассимиляции - $18.7 \%$, маргинализации - 22.4\%. Отмечено, что дискриминация со стороны принимающего общества препятствует нормальной интеграции мигрантов и толкает их к выбору модели маргинализации, создавая предпосылки для плохой психологической и социокультурной адаптации. Также выяснилось влияние интеграции как стратегии на формирование адекватной самооценки, 
психологического комфорта, снижение уровня тревожности, депрессии, психосоматических симптомов.

Положительное влияние стратегий на успех адаптации снижается далее соответственно в связи с выбором стратегий ассимиляции, сепарации, маргинализации. На приспособление к школьным требованиям, отсутствие поведенческих проблем оптимальным образом влияет стратегия интеграции, а затем ассимиляции и сепарации. Маргинализация находится на последнем месте по эффекту влияния на адаптацию подростков-мигрантов. Дж. Берри в исследовании не выявил различий в уровнях социокультурной и психологической адаптации у подростковиммигрантов и подростков из принимающего населения. По его мнению, «грамотная социальная политика, нацеленная на мультикультурализм, является важным формирующим фактором социальной адаптации мигрантов в новом обществе» $[1,378]$.

Поскольку все потребности личности взаимосвязаны, а успешность процесса адаптации по реализации одних потребностей оказывает влияние на другие, и место реализованных потребностей занимают другие потребности, автор обратился к теории самоактуализации А. Маслоу. По мнению последнего «человек постоянно испытывает какие-либо потребности. Среди них одни потребности выходят на первый план, доминируют и определяют характер и направленность поведения и деятельности человека, а другие потребности определяют общий стиль поведения и характер действий, их своеобразие» [2, 169].

В работе «Мотивация и личность» А. Маслоу описал иерархию потребностей человека, выделив следующие уровни:

- потребность в пище, отдыхе и удовлетворении потребностей, связанных с нормальным существование организма;

- потребность в безопасности, стабильности, защите от внешних угроз;

- потребность в социальных связях;

- потребность в признании со стороны общества;

- потребность в самоактуализации (развитие талантов, развитие способностей, эстетических идеалов, поиск и нахождение смыслов жизни и т.п.) По теории А.Маслоу достичь пятого уровня самоактуализации - цель жизни человека.

Автор данной статьи полагает, что структурную основу и содержательное наполнение частей, этапов любой модели, программы, проекта по адаптации личности должна составлять описанная иерархия потребностей. Поскольку новые репатрианты, как правило, в первые несколько лет вынуждены возвращаться к удовлетворению потребностей, перечисленных в первом уровне пирамиды А. Маслоу, то содержание работы 
коуча направлено на механизмы перехода к следующим ступеням пирамиды.

Вместе с тем, мы обратились к модели логических уровней Дилтса или технике неврологических уровней, как инструменту понимания собственных действий субъектом на разных уровнях. Это концепция, помогающая понять смысл действий человека на разных уровнях, обогатить смыслом свой путь и внедрить в себя новые ориентиры и новые личные ценности. Мы оценили модель Р. Дилтса как методологическую основу проекта адаптации подростков из семей иммигрантов, позволяющую

- обеспечить понимание движущих механизмов людей, систематически избегающих решения своих проблем.

- организовать мышление, собрать информацию, организовать межличностное общение;

\section{Пирамиоа Фиптса}

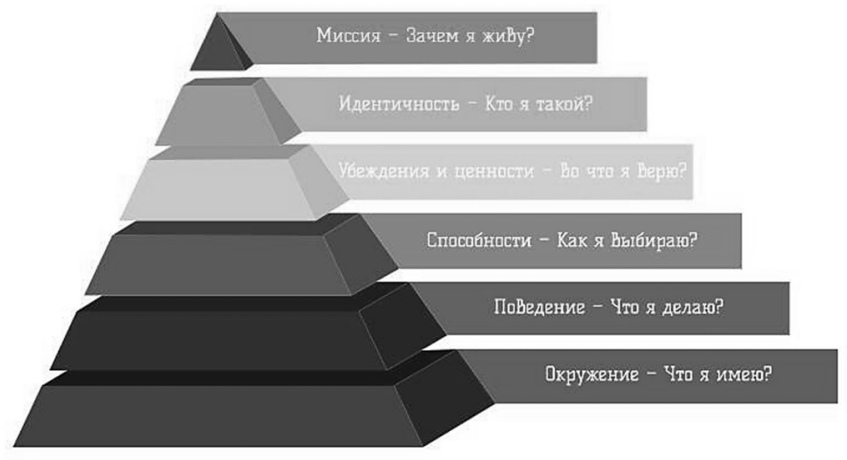

Рисунок 1. Модель логических уровней [3]

Таким образом, пирамида Дилтса нам нужна

- д для своевременного обнаружения сбоев в процессе адаптации;

- для развития точности и глубины общения подростков с другими людьми;

- для отслеживания происходящего в сфере самой личности, семьи, организации, команды и других формах партнерства.

Благополучная адаптация иммигрантов в целом и подростков в частности, во многом зависит от их самооценки и лидерских качеств. Именно эти составляющие успеха программа Андреа Моллой «12 шагов к исполнению желаний», на которую здесь ссылается автор, призвана 
развить у подростков- мигрантов. Программа реализуется посредством коучинговой технологии, позволяющей человеку, отвечая на вопросы, лучше понять себя, свои желания, устремления, ограничивающие убеждения и страхи, осмыслить их, набраться мужества, чтобы незамедлительно начать действовать, создавая свою жизнь по желанию и устремлениям. «Каждую неделю вы будете посвящать отдельному аспекту, осваивая новы е стратегии с тем, чтобы по окончании программы, вооружившись всеми необходимыми понятиями, стратегиями и инструментами, вы смогли полностью реконструировать свою жизнь». [4, 9]

Коучинговая технология, лежащая в основе программы, базируется на социальном проекте, проведенном Андреа Моллой, специалистом по коучингу с группой, состоящей из 10 добровольцев. Результатом проделанной работы, стала книга Лайф-коучинг «Меняю жизнь».

Программа подразумевает 12 этапов и длится 12 недель.

Основой стратегии данной программы стала идея модели GROW. Каждую неделю мы формируем конкретную цель(GOAL), проверяем реальное положение дел (Reality chek), анализируем варианты(Options), берём курс только вперёд (Way forward). Каждая неделя посвящена отдельному аспекту, вооружающему участников новыми стратегиями, инструментами, понятиями, которые станут платформой для изменения жизни.

Краткое содержание каждой недели:

Неделя 1. Первые шаги

Анализ, критическая оценка своей жизни. Неделя 2. Здоровая жизнь

Необходимость здорового образа жизни, как правило. Неделя 3. Прекрасная физическая форма

Превращение занятий спортом в неотъемлемый элемент своей жизни. Неделя 4. Правильное питание

Неделя 5. Возрождённые отношения

Как наладить отношения с теми, кто дорог и завести новые знакомства. Неделя 6. Оценка прогресса на середине пути

Поддержка, поощрение, анализ Неделя 7. Удовольствие от работы

Неделя 8. Пусть деньги работают на вас Неделя 9. Жильё

Дом - уютное убежище

Неделя 10. Позитивный настрой Неделя 11. Весёлая жизнь

Неделя 12. Завершающий этап.

Такая структуризация программы делает ее адаптивной к новым условиям, что позволяет расширить рамки ее применения, в частности использовать в работе с подростками-мигрантами и их семьями. 
Автор в рамках профессиональной деятельности, базируясь на программе известного мастера-коучера Андреа Моллой и сохраняя структуру этой программы, осуществил работу по содержательному наполнению этапов, ориентируясь на адаптацию подростков-мигрантов через лайф-коучинг, апробировал эффективность Лайф-коучинга в индивидуальной работе, сочетая её с другими формами и технологиями консалтингом, тренингами.

Цель проекта: создание предпосылок для успешной адаптации подростков-мигрантов.

Задачи:

- повышение уровня адаптации подростков;

- формирование адекватной самооценки;

- активизация внутреннего ресурса подростков для интеграции в общество принимающей страны.

Осуществлялась работа с группой подростков (10 человек) - новых репатриантов, находящихся менее семи лет в стране. Каждый из них, преодолевая трудности иммиграции, выпал из нормативной системы образования, проживает в неблагополучном районе города и, подражая ближайшему окружению, воспринимает их культурные коды как модель поведения. Проблемы усугубляются трудностями в освоении языка принимающей страны. Практически их жизнь и жизнь их семей - это борьба за выживание. Решая проблемы выживания, родители не имеют возможности помочь социализации своих детей.

На основе полученных сведений были сформулированы следующие факторы, с учетом которых моделируется работа в данном проекте:

- у подростков-мигрантов уровень адаптации к социальной среде и таких ее характеристик, как самопринятие и эмоциональная комфортность, снижен;

- существуют различия в уровне и сущностных характеристиках социально-психологической адаптации подростков с различным социокультурным статусом;

- для моделирования работы важно изучать и учитывать «Образ Я» и представление каждого о возможности контролировать свою жизнь;

- родители подростков также нуждаются в адаптации и социализации»;

- приглашенные в программу подростки находятся на первой ступени развития потребностей по шкале А. Маслоу и, соответственно, на первом уровне пирамиды Р. Дилста.

Новизна предложенного проекта заключается в том, что субъектом работы являются подростки-мигранты и их семьи. Содержательное наполнение каждого шага, а их 12, представлено техниками и 
информацией, соответствующими возрастным особенностям участников проекта. Соотношение индивидуальной и групповой работы - 60\%: 40\%. Параллельно в проекте заняты подростки - мигранты и их родители. На завершающем этапе проводятся совместные сессии, организуется диалог в разновозрастной группе. Обязательно для сохранения полученных результатов продолжать работу в течение полугода, организуя ежемесячные встречи - «пики» с самоотчетами, презентациями, одобрением и поощрением успехов.

Оценка и самооценка результатов работы осуществлялась по 10-ти бальной шкале. Отметку 8-9 баллов выставили 10 из 10 участников, что позволяет сделать вывод о сформированности предпосылок для дальнейшей адаптации и развития, создании предусловий интеграции как стратегии поведения подростков в принимающей стране.

\section{Список литературы:}

1. Берри Дж. Кросскультурная психология. Дж. Берри, Х. Сигалл. М., 2007.- $560 \mathrm{c}$.

2. Маслоу А. Мотивация и личность / А. Маслоу. - СПб.: Питер, 2013. - 352 с.

3. Моллой А. М75 Лайф-коучинг. Меняю жизнь!/А.Моллой;пер.с англ.Е.А. Бакушева. - Минск: "Поппури",2010. - 272 с.

4. Убеждения и привычки. Как изменить? 2013, Роберт Дилтс. 


\title{
PEDAGOGY
}

\author{
SECTION 1.
}

GENERAL PEDAGOGICS, PEDAGOGICS AND FORMATION HISTORY

\section{EDUCATION OF THE DOMESTIC SPIRIT OF STUDENTS OF PROFESSIONAL EDUCATIONAL INSTITUTIONS}

\author{
Komil Abdullaev \\ Independent researcher of \\ Tashkent State Pedagogical University, \\ Uzbekistan, Tashkent
}

\section{ВОСПИТАНИЕ ОТЕЧЕСТВЕННОГО ДУХА СТУДЕНТОВ ПРОФЕССИОНАЛЬНЫХ ОБРАЗОВАТЕЛЬНЫХ УЧРЕЖДЕНИЙ}

Абдуллаев Комил

соискатель Ташкентского государственного педагогического университета, Узбекистан, г. Ташкент

\footnotetext{
ABSTRACT

This article discusses the formation of patriotic qualities of students of vocational education in the system of continuing education.
} 


\section{АННОТАЦИЯ}

В статье рассматриваются вопросы формирования патриотического духа у студентов профессиональных учебных заведений в системе непрерывного образования.

Keywords: education, vocational training, quality, patriotism, student, educational institutions.

Ключевые слова: образование, профессиональная подготовка, качество, патриотизм, студент, образовательные учреждения.

The relevance of research. The problem of the spiritual and moral education of the younger generation, which is destined to build a new Russia, is especially acute today. The core of all Russian education has always been patriotism. However, in the $90 \mathrm{~s}$ of the XX century, the paradigm of communist education changed to variable educational systems, the destruction of value structures, called the axiological crisis, which became another in a long list of other "crises". Activities aimed at the development of patriotism among young people were subjected to destructive criticism, which largely contributed to discrediting not only the existing practice of patriotic education, the whole huge effort of organizing and conducting it, but also the very idea of forming the personality of a citizen of a patriot. During this period, the state's attention to education decreased, which led to a weakening of the work of educational institutions in this direction. This fully applies to professional education and upbringing as an integral part of a person's socialization system, the formation of his personality.

The study of the philosophical and pedagogical works of Russian thinkers N.A. Berdyaeva and V.I. Vodovozova, N.Ya. Danilevsky, I.A. Ilyina, V.N. Magpies of Rosinsky, B.C. Solovyova, V.Ya. Stoyunin, K.D. Ushinsky made it possible to establish that the main ideas on the basis of which the upbringing of patriots in the pre-revolutionary period was carried out were: reliance on nationality, on national identity and the Russian idea; the creation of a Russian national school, the connection of patriotism with citizenship, with moral qualities, including Orthodox morality. The upbringing of patriots in Russia was based on estates and class, loyal sentiments; the best examples of literature, painting, art, examples from history, local history, a harmonious combination of national and universal values, the development of tourist-excursion and extra-curricular socially useful work, characterized by a wide variety of means, forms and methods, the creation of a system of patriotic education, purposefulness and constancy of character patriotic work. 
Analysis of the pedagogical literature of the Soviet period in the history of the Fatherland (1917-1991) showed that Soviet socialist patriotism was viewed as an ideological and political quality, while observing the principle of partisanship and the class approach. Pedagogical science and practice have achieved visible success, having accumulated rich theoretical and methodological potential. The supranational idea was realized, friendship and brotherhood of peoples of different nationalities were strengthened, interethnic harmony was achieved, the need and ability to live in the interests of society and the state were formed. Patriotic education was carried out in a team and with the help of a team, by involving young people in practical, conscious, socially useful activities, student self-government was used, a variety of forms of military patriotic education, a huge experience of museological and local history work.

Analysis of modern studies of the problem of patriotic education by such authors as M.P. Buzsky, A.N. Vyrshchikov, I.N. Glazunova, A.V. Lutovinov, SV. Marzoev, A.V. Petryankina, M. Rat, Yu.N. Trifonov and others, made it possible to state the presence of a pluralistic nature of patriotic consciousness in the context of the search for a national idea of the development of Russia, the organization of education of patriotism, taking into account the principles of democratization and humanization based on universal human values, respect for the country's cultural heritage, and also to determine the main approaches (ideological, value, creative, systemactivity, competence) to understanding the essence of patriotism and the organization of patriotic education of the younger generation. Patriotism is viewed as an ideology, principle, personality quality, feeling, as a specific feature of the Russian mentality, spiritual and religious self-manifestation of personality. It has been established that patriotism, being a broader concept, includes nationalism, since it does not deny the existence of ethno-national pride and ethno-national identity, but unites citizens on the basis of belonging to one country, its history, culture, political system. A number of researchers believe that patriotic education contributes to the formation of citizenship, which is quite natural, since a patriot - this is, first of all, a citizen of his Fatherland. This circumstance was taken into account when developing the value basis of patriotic education, the components of which were civic activity, the rule of law, the priority of public and state interests over personal, etc.

Various manifestations of patriotism were systematized: love for the Motherland, Fatherland, for native places, for the native language, knowledge of the history of the Motherland, respect for the traditions and customs of the people, understanding of the general political situation in the world, the tasks faced by the native country, intolerance of national, racial hostility, respect for other peoples, countries, the desire to defend the honor 
and dignity of the Motherland, active and conscious participation in labor activities for the good of the Motherland, readiness to serve the interests of their country, readiness to defend their Fatherland. Researchers identify different forms of patriotism: public and personal, true and false, state, Russian, Soviet, local, civil (constitutional), one-national, popular, liberal, Orthodox. This diversity has made it possible to work on a wide range of forms, methods and means in working on the content of this concept in educational activities.

At the present stage have devoted their dissertation research to S.A. Alieva, I.N. Glazunova, Yu.V. Lazarev, A.P. Petryankina, D.M. Magdiev, S.I. Meshkova, V.V. Piontkovsky, V.N. Ustyakin; students of cadet corps S.N. Smirnov; cadets of military higher educational institutions and students V.A. Belovtsev, S.N. Vinnikova, T.P. Gvozdev, V.E. Kucherov, I.I. Melnichenko, A.S. Rybinchuk, V.E. Utkin, A.V. Fadeev, Sh.Sh. Khairullin. Based on the analysis of the works of these authors, the concept of patriotic education of students was refined as the formation of patriotic feelings, patriotic consciousness and behavior, the civil and patriotic position of the individual and socially significant motivation of patriotic activity, taking into account the characteristics of the age of early adolescence as a period of conscious self-determination and professional self-realization Organization of patriotic upbringing in school is a purposeful process of interaction between students, teachers and social partners of an educational institution of secondary vocational education in the formation of patriotism, which manifests itself in the readiness to realize oneself in the chosen professional activity and socially significant actions, following the traditions of serving the Fatherland.

The developed model of organizing the patriotic education of secondary school students as the main components within the framework of a holistic pedagogical process includes: principles, innovative approaches, concept, purpose, objectives, conditions, subjects of activity, content, means, forms and methods, variable technologies, results, correction.

In the system of upbringing patriotism, the following groups of methods were used: the formation of a person's patriotic consciousness (views, ideas, knowledge, concepts, ideals); organization of various types of activities, including communication, experience of patriotic behavior; self-control, selfesteem, self-reflection; stimulation, motivation of activities and behavior. Groups of funds were represented by such blocks as material, technical, educational and organizational means. The content included a set of reliable, exhaustive and modern scientific knowledge of a patriotic nature, value orientations. 


\section{References:}

1. Voronina I.K. The meaning, methods and forms of civil-patriotic education of student youth // Young scientist. 2015. No. 7.3. S. 4-5.

2. Snopko N.M. Psychological mechanisms and pedagogical foundations of patriotic education in the vocational education system: author. diss .... doct. ped. sciences.M., $2007.47 \mathrm{p}$.

3. Bondarenko E.A. Models of patriotic education in modern conditions // Internet and education. 2009. No. 15. [Electronic resource]. Access mode: http://www.openclass.ru/node/83656 (date of access October 21, 2017).

4. Junco R. The effect of Twitter on college student engagement and grades / Junco R., Heiberger G. and Loken E // Journal of Computer Assisted Learning. 2011. No. 27, pp. 119-132. [Electronic resource]. - Access mode: http://onlinelibrary.wiley.com /doi/10.1111/j.1365-2729.2010.00387.x/pdf. (date of circulation 10/21/2017).

5. Siemens G. Connectivism: a learning theory for the digital age. 2004. [Электронный pecypc]. - Available at: www.elearnspace.org/Articles/connectivism.htm. (date of circulation 20/10/2017).

6. Zavada G.V., Lyaukina G.A. Possibilities of using social networks in higher education. Innovations in vocational and vocational pedagogical education // Materials of the 20th All-Russian Scientific and Practical Conference. RGPPU: Yekaterinburg. 2015.S. 241 - 244.

7. Kovalenko G.A., Haertdinova G.A. Social network of the world wide web Internet as a potential model of learning (on the example of the social network "VKontakte") // Modern problems of science and education. 2014. No. 3 (53). [Electronic resource]. - Access mode: http://www.science-education.ru/117 (date of access October 21, 2017).

\section{THE ROLE OF HISTORICAL ARCHITECTURAL MONUMENTS IN THE FORMATION OF NATIONAL PRIDE BY PRESCHOOL ADULT CHILDREN}

Shakhnoza Khasanova

Lecturer,

Tashkent State Pedagogical University,

Uzbekistan, Tashkent 


\begin{abstract}
This article discusses the formation of national pride in older schoolage children, the role of historical architectural monuments in the formation of national pride.
\end{abstract}

Keywords: national pride, historical monument, child, upbringing, aesthetic upbringing, upbringing, youth.

The development of a sense of homeland among young people is one of the important factors of the high spirituality of the nation. Our country has created ample opportunities for the study and dissemination of the rich cultural and historical heritage of our ancestors, the scientific and spiritual values of the people. National identity determines the place and status of a particular person in the national society, in his countries. The introduction of national identity is carried out through the strengthening of the national basis of the content of education, the creation of methods for enriching the national component of the content of education. In this regard, the study of the course of history of Uzbekistan in secondary schools of the Republic uses a variety of sources that reflect historical facts and events, in particular, architectural monuments, acquaintance with which allows students to gain a deeper understanding and mastery of historical knowledge. information to form an interest and respect for the historical past.

The architectural monuments and structures of our country (and their number is very small) testify to the fact that the folk culture of a certain historical period, when acquainted with them, developed in accordance with a certain historical idea. the period is formed in the minds of students. When you visit many restored and restored, renewed memorable historical sites palaces, pavilions, monuments, students will be enriched with historical knowledge about the development of society and culture of their countries. The study of this process is an important pedagogical problem today. From the first days of independence, the main problem of political scientists and scholars was an objective assessment of the historical development of Uzbekistan. Every element of these positions, every fact of national history has been fully explored and strong social policies, in particular the sustainable development of the education system, including history education, have been identified as priorities for social development. and the economic development of the young state.

In turn, historians, educators - scientists and methodologists have studied various aspects of the study of historical sciences, for example, the effectiveness of the use of interdisciplinary links in the teaching of history. However, despite the fact that the use of architectural monuments as a 
means of developing students' feelings about the Motherland was considered one of the most pressing issues, it was not the object of special scientific research. In his works, the first President of the Republic of Uzbekistan IA Karimov emphasizes the importance of national and cultural values for the spiritual and moral upbringing of the younger generation, the historical approach to the restored values among young people, the formation of feelings. national pride in the past and present of its people. The use of materials related to the history of architecture opens wide prospects for educating students in the spirit of love and respect for the Motherland and its history, deepening historical knowledge.

In-depth study of the history of the Uzbek people, a correct understanding of the essence of historical processes, awareness of social events, life and activities of national heroes, materials about the architectural heritage of our ancestors - all this together creates conditions for students to develop a sense of homeland.A.Abdullaev, E.Azimov, B.Aminov, B.Akhmedov, H.Samatov devoted their researches to this problem, they revealed the national-historical process, its influence on the formation of national-ethnic personality traits. the world history of the nation (people) in development. The research results of these authors are being used effectively in the historical education process. Architectural monuments have a worthy place in the system of historical national values. The creation of science-based content and methods of studying them increases the effectiveness of history education. In the early years of independence, methodological inconsistencies, errors, and objectivity were characteristic of some historical assessments for the study of history.

The study of architectural monuments is mainly limited to the example of structures associated with a certain historical period in the Turkestan region in the 18-19 centuries. Only this heritage was believed to be enlightening. During the years of independence, the cultural heritage has been enriched with new architectural structures erected in memory of our great ancestors. Thus, the State Museum of the History of the Temurids, the Squares of Memory and Martyrs were built in Tashkent, and the Khasti Imam architectural ensemble was restored. Familiarization with these historical monuments has a great educational effect on the formation of national pride in children. The process of educating children in the spirit of devotion to the Motherland on the basis of historical and architectural monuments requires a comprehensive approach. In the first stage, an excursion will be organized directly to the monument. In the second stage, children express their impressions of visiting historical places and consolidate their impressions of independent creative activity. 
In the third stage, the educator summarizes the children's pictures, videos, stories, and opinions expressed to them in the comments. Undoubtedly, such a didactic system helps to increase the effectiveness of lessons and independent work, as historical monuments with their content and rich visual aids help to awaken in children a sense of national pride, devotion and love for the Fatherland.

One of the urgent problems of state policy is to inculcate in the hearts and minds of children the content and essence of high "spiritual", "moral", "cultural", "aesthetic" concepts on the basis of the "First Step" program. In this regard, the ongoing large-scale socio-spiritual reforms in the Republic of Uzbekistan, the rapid development of science and technology and production - raises the issue of educating a person who can meet the needs of society.

Indeed, today it is important to direct young people, who are the foundation of the future, responsible in all respects, who can personally take the initiative for the development of society. In this regard, the age and specific psychological, physiological and physical capabilities, interests, abilities and needs of children in preschool education are taken into account.

During the experimental work, pupils of preschool educational institutions used educational lessons that serve to form elements of national pride in preschool children through historical architectural monuments. The fact that the educators involved in the experimental work were offered training, the technology of organizing virtual excursions, not only ensures the effective conduct of the process, but also allows you to make the most of the time.

The development of methods of patriotic education in preschool education is of great importance. For the successful formation of patriotism it is necessary to give children a basic knowledge of the Motherland, the country, the people, history, culture. Patriotic education includes the spiritual and moral aspects of shaping the worldview, which in turn allows to cultivate a loving heart. It is important that patriotic education has a spiritual and moral character. The upbringing of a patriot who knows the history of his country and his country, who loves his homeland, cannot be done without mastering the culture of the people and understanding the spiritual values of his people.

\section{References:}

1. Ruzieva D.I. Forming a sense of national pride in students. - T .: "Fan", 2007.

2. Musurmonova O. Family spirituality is a national pride. - T .: "Teacher", 1999.

3. Ibragimov A. et al. Sense of homeland .. - T .: "Uzbekistan", 1996. 
4. Bondarenko E.A. Models of patriotic education in modern conditions // Internet and education. 2009. No. 15. [Electronic resource]. Access mode: http://www.openclass.ru/node/83656 (date of access October 21, 2017).

5. Junco R. The effect of Twitter on college student engagement and grades / Junco R., Heiberger G. and Loken E // Journal of Computer Assisted Learning. 2011. No. 27, p. 119-132. [Electronic resource]. - Access mode: http://onlinelibrary.wiley.com /doi/10.1111/j.1365-2729.2010.00387.x/pdf. (date of circulation 10/21/2017).

6. Siemens G. Connectivism: a learning theory for the digital age. 2004. [Электронный pecypc]. - Available at: www.elearnspace.org/Articles/connectivism.htm. (date of circulation 20/10/2017).

7. Zavada G.V., Lyaukina G.A. Possibilities of using social networks in higher education. Innovations in vocational and vocational pedagogical education // Materials of the 20th All-Russian Scientific and Practical Conference. RGPPU: Yekaterinburg. 2015.p. 241 - 244.

8. Kovalenko G.A., Haertdinova G.A. Social network of the world wide web Internet as a potential model of learning (on the example of the social network "VKontakte") // Modern problems of science and education. 2014. No. 3 (53). [Electronic resource]. - Access mode: http://www.science-education.ru/117 (date of access October 21, 2017). 


\title{
ҚАЗАҚ ТІЛІНДЕГІ КОНФЕРЕНЦИЯ \\ БАЯНДАМАЛАРЫ
}

\author{
ПСИХОЛОГИЯ
}

1-БӨЛІМ.

ПЕДАГОГИКАЛЫҚ ПСИХОЛОГИЯ

\section{ЖЕКЕ ТУЛҒАНЫН ТАНЫМДЫК ҮРДІСТЕРІНІН ДАМУЫ МЕН ҚАЛЫПТАСУЫНЫН МУМКІНДІКТЕРІ}

\author{
Әліпбек Ардақ Зәуірбекқызы \\ n.z.к., доиент м.а., \\ Оңтүстік Қазақсттан \\ мемлекеттік педагогикалық университеті, \\ Қазақсстан, Шымкент \\ Бахрамова Гульмира Абдурасуловна \\ n.z.к., ава оқыьтушы, \\ Оңзтүстік Қазақсттан \\ мемлекеттік педагогикалық университеті, \\ Қазақстан, Шымкент \\ Джсанибекова Мухлиса Мирзакаримовна \\ 5В010300 - Педагогика және психология мамандывы, \\ 4-курс студенті, Оңтүстік Қазақсттан \\ мемлекеттік педагогикалық университеті, \\ Қазақ̧стан, Шымкент
}




\title{
Жәнділла Қайнар Серікұлы
}

7М01110-«Педагогика және психология»,

1-курс магистранты, М.Әуезов атындавы Оңтүстік Қазақстан университеті, Қазақстан, Шымкент

\begin{abstract}
АННОТАЦИЯ
В данной статье рассматриваются особенности профессиональной деятельности педагога-психолога в системе обновленного образования. Кроме того, в работах ученых-исследователей проанализированы виды профессиональной деятельности педагога-психолога как специалиста вспомогательной профессии.
\end{abstract}

\section{ABSTRACT}

This article discusses the features of the professional activity of a teacher-psychologist in the system of updated education. In addition, the works of researchers analyzed the types of professional activities of a teacherpsychologist as a specialist of the auxiliary profession.

Адамның қалыптасуына оны қоршаған ортаның: табиғи, әлеуметтік жағдайдың тигізер әсері өте зор. Адамның әлеуметтік ортасы оны тікелей қоршап тұрған орта - отбасы, құрдастар, көршілер, сыныптас ұжым. Бұларда адамның қалыптасуы жүзеге асады. Кең мазмұнда алғанда әлеуметтік топ дегейіміз - адамдардың маңайындағы үлкен топ: қоғамдық тап, ұлт, ел, қоғам, сонымен қатар адам өмір сүріп отырған қоғамдағы жағдай.

Ірі әлеуметтік топтар өзара байланысты шағын топтардан (3-5, 10-15 адам) тұрады, олар белгілі әдет-ғұрыпқа, нормаларға негізделіп, қалыптасады. Адамға әсіресе, жастық шақта күшті әсер ететін орта отбасы, оның мүшелері ғана емес, ата-аналар, әке мен шеше, сонымен қатар онда қалыптасқан әдет-ғұрып, дағды.

Отбасында адамның мына сапалары қалыптасады: көпшілдік немесе тұйықтық, еңбек сүйгіштік немес жалқаулық, ұқыптылық немесе ұқыпсыздық, ақкөңілдік немесе өшпенділік, әділдік - әділетсіздік, адалдық - арамдық, ұяттынық немесе ұятсыздық. "Отбасы - адамның өте маңызды, өте жауапты ісі. Отбасы адамды кемеліне келтіреді [1].

Қоғам адамға бірінші кезекте мәдениет пен қоғамда, адамдар арасында қалыптасқан қатынастар арқылы әсер етеді. Адамның қалыптасуына үлкен әсер ететін ғылым, өнер және бұқаралық ақпарат құралдары - баспасөз, радио, теледидар, білім және адам өмір сүріп, еңбек 
етіп отырған қоғамдағы жағдайлар. Сонымен, жеке тұлғаның дамуына бірнеше фактор ықпал ететіндігін келесі 1-сызбадан көруге болады.

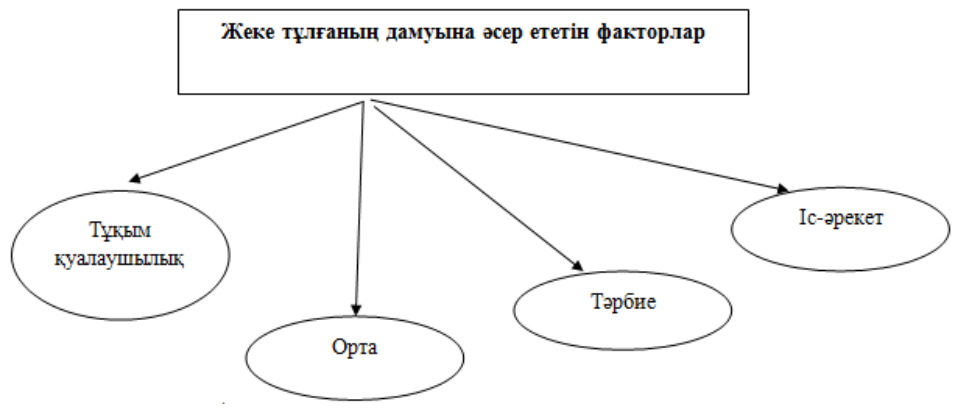

\section{Сызба 1. Жеке тұлваның дамуына әсер ететін факторлар}

Адамның адамгершілігі - оның ең жоғарғы қасиеті. Оның негізгі белгілерінің бірі - өзі үшін ғана емес, ел, қоғам үшін өмір сүру, адамдық ар-намысты ардақтау, кез-келген уақытта жақсылық жасауға дайын болу. "Өзің үшін еңбек қылсаң, - дейді Абай, - өзі үшін оттаған хайуанның бірі боласың. Досыңа достық, - қарыз іс, дұшпаныңа әділ бол". Ақылды, мейірімді адам әр уақытта өзгенің жақсылығын бағалағыш келеді. Арлы адам - ардақты. Біздің өткен тарихымыз - біздің арымыз. Арымыз таза болса, тарихымыз да таза. Осы сапаларды өз бойларына сіңіру әрбір оқушының ұстанған бағыты, нысанасы болуы керек. Себебі адамгершілігі мол адам - басқаларга үлгі-өнеге [2].

Кез-келген танымдық үрдіс бейнелеу және реттеу қызметін атқарады. Бірақ бейнелеу қызметінен басым үрдістер (танымдық үрдістер) және реттеу қызметінен басым психикалық үрдістерді (эмоция, ерік) бөліп көрсетуге болады.

Танылдық үрдістер жүйесіне келесі үрдістер кіреді: түйсік және қабылдау, зейін, ес, қиял, ойлау, сөйлеу, эмоция.

Танымдық үрдістер жүйесінің барлық жүйелі блоктары үнемі өзара әрекеттесу үрдісінде болады және танымдық іс-әрекеттің бірлігін қамтамасыз етеді. Танымдық процестер жүйесі өзара әрекеттесу үрдісінде үнемі аралық нәтижелер көрінеді.

Танымдық үрдістер жүйесі бірінші блогынан екіншісіне ауысқандағы ақпараттың қандай өзгерістерге ұшырайтыны көрсетілген (синусоида түрінде кестеде бейнеленген). Танымдық үрдістер жүйесі жұмысының соңғы нәтижесі алынған материалға сәйкес келеді, бірақ оның тура көшірмесі болмайды (кестеде қысқа сызықтармен бейнеленген). Сонымен, танымдық үрдістер жүйесінің жұмысы 
адамның объективті шындықты адекватты субъективті бейнелеуін қамтамасыз етуден тұрады.

А.В.Запорожец периептивті әрекеттердің қалыптасуы оқытудың әсерімен бірнеше деңзейлерден өтеді деп есептейді:

I-деңзей - адекватты перцептивті бейне, балада материалдық заттармен тәжірибелік әрекет жолымен жүреді;

II-деңцееи - сенсорлық үрдістер өз қозғаласының көмегімен орындалатын рецептивтік аппараттарды орындайтын өзінше перцептивтік әрекетке айналдырады. Балалар заттардың кеңістіктік қасиетін қол мен көздің бағдарланып - зерттеу қозғалысының көмегімен танысады;

III-деңзей - перцептивті әрекеттерді қысқарту үрдісімен басталады;

$I Y$-деңзгей - перцептивті үрдістер дәріптенеді яғни идеалды түрге айналады[3]. Балалар тез және қандай да бір сыртқы қозғалыстың көмегінсіз - ақ қабылданатын обьектілердің белгілі бір қасиеттерін танып, осы қасиеттер негізінде оларды бір-бірінен айыра алу қабілілеттілігіне ие болады.

Сонымен, адамның мазмұны - қоғамдық қатынастың жиынтығы. Алайда, бұл қатынас өзгермей қалмайды, тұрақты түрде бірқалыпта тұрмайды, ол қоғамның өзгеруіне орай жаңаланып отырады. Бұл дегеніміз адамның да мазмұны өзгереді деген сөз, сондықтан да ең алдымен адам өмір сүретін қоғамды өзгерту қажет.

\section{Әдебиеттер тізімі:}

1. Жарықбаев Қ.Б. Психология негіздері. - Алматы: «Эверо», 2005.

2. Джакупов С.М. Психология познавательной деятельности. - Алма-Ата, 1992.

3. Қазақ тілі терминдерінің салалық ғылыми түсіндірме сөздігі. Педагогика және психология. - Алматы: «Мектеп» баспасы, 2002.

4. Жақыпов С., Бердібаева С. Психологиялық зерттеу нәтижелерін статистикалық өңдеу тәсілдері. - Алматы, 1998.

5. Сейтәлиев Қ. Жалпы психология. - Алматы: Білім, 2007.

\section{ЖАС ҰРПАҚТЫ ҰЛТТЫК БІРЕГЕЙЛІКТІ САҚТАУҒА ТӘРБИЕЛЕУДІН МУМКІНДІКТЕРІ}

\section{Қойшиев Қалдан Елеуұль}

n.z.к., ава оқылтушы,

Онттүстік Қазақсстан мемлекеттік педагогикальқ университеті, Қазақстан, Шымкент 
Әліпбек Ардақ Зәуірбекқызы

n.z.к., доиент м.а.,

Оңттүстік Қазақстан мемлекеттік педагогикалық университеті,

Қазақстан, Шымкент

Танабаева Гульмира Тулебаевна

ф.z.к., ава оқыытушы,

Оңтүстік Қазақстан

мемлекеттік педагогикальқ университеті,

Қазақстан, Шымкент

Ибрай Еңлік Ибрайқызы

5В010300 - Педагогика және психология мамандызы, 4-курс студенті,

Оңзтүстік Қазақстан мемлекеттік педагогикалық университеті, Қазақстан, Шымкент

\begin{abstract}
АННОТАЦИЯ
В этой статье рассматривается важность психологических подходов к воспитанию молодежи к сохранению национальной идентичности. Вместе с тем, он связал понятие «этническая идентичность» с психологическими взглядами в трудах Ж. Аймауытулы.

\section{ABSTRACT}

This article examines the importance of psychological approaches to educating young people to preserve national identity. At the same time, he linked the concept of "ethnic identity" with psychological views in the writings of J. Aimauytuly.

Ел президенті Н.Ә.Назарбаевтың «Біз өзіміздің тілімізді, дінімізді, жеке бас ерекшелігімізбен сақтай аламыз және біз осы рухпен біздің жастарды тәрбиелеуіміз тиіс» - деп атап көрсетілді жолдауда [1].

Ұлтымыздың да, еліміздің де өзін-өзі анықтаудың іргелі негіздері бар. Олар: 1) Тәуелсіздікке деген, «Ұлы Жібек жолын» қайта жаңғыртуға деген бағыт-бағдар; 2) бірдей еңбектену, халық бірлестігі, тарихтың, мәдениеттің ерекшелігін ескеру және мемлекеттік тілді қолдану жүйесін жетілдіру әрекеті; 3) қазақтың ұлттық мәдениетін толықтыратын тәжірибе сабақтастығы. Қоғамды жетілдірудің осындай қазақстандық тәжірибесін әлем мойындауда [2].
\end{abstract}


Этникалық бірегейлік - этникалық қауыммен өзінің ұқсастығын ғана емес, оны бағалауды, оған мүше болудың маңызын бөлісетін этникалық сезімін (абырой, бедел, реніш, қорқыныш сезімі) жете ұғынуы. Этникалық сезім - этникааралық салыстырудың маңызды өлшемдері, бұл сезімдер индивидтің әлеуметтену үдерісінде қалыптасатын адамның этникалық қауыммен терең эмоционалдық байланысы және моралдық міндеті бойынша сүйенуі болып табылады.

Психологтар этникалық бірегейлікті қалыптастыруға ықпал ететін факторлардың ішінен бөліп көрсетеді:

1) отбасында, мектепте және әлеуметтік ортада этникалық әлеуметтенудің ерекшеліктерін;

2) этнобайланысты ортаның, алдымен гетерогендіктің/ гомогендіктің ерекшеліктерін;

3) этникалық топтар арасындағы мәртебелік қатынастар.

Этникалық бірегейлікті (этникалық гипоидентичность) жоғалту тұтас алғанда, адам үшін жағымсыз себептерге алып келеді. Өзінің маңызын және ұлттық бірегейлігін, сонымен қатар өзінің мүмкіндіктері мен қабілеттерін жете ұғынбауы, адамның ішкі жағынан азат етілмеуі, өзіне қысым көрсетуі, жасқаншақтауы, өзінің мәдени «Менін» басуға тырысуы, оны ішкі кикілжіңге алып келеді. Ол өзіне деген сенімін жоғалтады немесе оны тіпті де меңгермейді, ынтасыз, өзін қорғай алмайды және басқаның айласының пассивті объектісі болып қалыптасады [3].

Ю.В.Бромлей этностың өзіндік белгілерін қалыптастыруда аз да болса рөл атқаратын өзіндік әлеуметтік-психологиялық тетіктерін, атап айтқанда, сендіру, еліктеу және өзара жұқтыруды ерекше атап көрсетеді [4]. Сонымен бірге ұлттық сана-сезімді қалыптастыруда сәйкестендіру (идентификация), эмпатия, децентрация, стереотипизация, рефлексия және т.б. әлеуметтік-психологиялық тетіктер маңызды рөл атқарады.

Өз халқының мәдениетіне (ұлттық мәдениетіне) қатыстыру әрі меңгеру ұлттық рухани құндылықтарды және нормаларды интериоризациялайды. Яғни, тұлға өзін сол халықтың бөлігі ретінде сезінеді. Ұлттық мәдениет сол ұлтқа тән материалдық және рухани құндылықтардың, нормалар мен моралдың, құқықтың, салт пен дәстүрдің, өнердің, әлеуметтік және саяси құбылыстардың жиынтығы. Осыған байланысты, 20 ғасырдың басында қазақ халқының ұлттық бірегейлігін сақтауда Ж.Аймауытұлының Жүсіпбек Аймауытұлының психологиялық мұралары зор мәнге ие. Бұл қазақ топырағында өте сирек кездесетін құбылыс, өйткені мыңдаған жылдар бойына рухани мұрасы жалғасып келе жатқан халыққа ғылыми психологияның найзағайдай жарқ ете қалуы 
заңды да болатын. Ж.Аймауытұлының еңбегі - бүкіл түркі халықтарында белгілі жүйемен ғылыми астармен жарық көрген тұңғыш еңбек.

Ж.Аймауытұлы өз туындыларын жазуда батыста және орыс елінде жарық көрген психологиялық еңбектердің, оқулықтардың, оқу құралдарының Л.С.Выготскиймен бірге психологияның жаңа ғылыми негіздерін кұруға ат салысқан П.П.Блонский (1884-1941) енбектері Ж.Аймауытұлының психологиялық оқу құралын жазуына арқау болғаны байқалады.

Ж.Аймауытұлы ескі психология адамдарды өзгеріске түспейтін, қатып-семіп, шыныққан зат күйінде қарастырады деп мұны өте теріс, мұндай түсінікпен келісуге болмайды дейді. Оның пікірінше, адам өзгермелі, құбылмалы жәндік. Оның жәндік деп тұрғаны бір есептен дұрыс та, өйткені адам ұғымы да организм деп аталатын текті ұғымға кіреді. Бір кезде ұлы Аристотель де адамды сөйлейтін жануар деген болатын. Олай болса, адам өзгермелі, құбылмалы жәндік деген сөздің бір жағынан оғаштығы жоқ. Адам қоршауының өзгеруіне байланысты қылығы да өзгеріп отырады. Аймауытұлының пікірінше, ғылымға сүйенген психологияның мақсаты - адамның қылығы не себептен өзгеретінін, ол өзгеріс неден туатынын, қалайша қалыптасатынын табу болмақ.

Аймауытұлы өзінен бұрынғы психология ғылымы жайында айтқандардың қисындарын сынай келе, бұрынғы жан тамыршылары көбінде адам туралы жазғанда «Мен» деген ұғымға жүгінетін еді дейді. Олар адамды әлеуметтен бөліп алып, оның жеке басын тексеруді ойластыратын. Ал Ж.Аймауытұлының пікірінше, жеке адамның қылығын әлеуметтен тыс қарастыру мүмкін емес.

Ж.Аймауытұлының ұлттық тәлім-тәрбиелік терминдер жасау мәселесіне ерекше көңіл бөлуі - оның сол кездегі әлеуметтік сұраныстан туындағаны да белгілі. Өйткені, Қазан төңкерісінен кейін жер-жерде ашыла бастаған жаңа типтегі казақ мектептеріне түрлі пәндерден оқулықтар мен оқу құралдарын дайындау қажеттігі, сондай-ақ ұстаздар үшін әдістемелік құралдар жазу мәселесі, сайып келгенде, бұл ұлттық мектептің жаңа жүйесін жасау ісіне ерекше маңыз алатын мәселе еді.

Автордың жалпы ғылыми терминдер жасау жөніндегі принциптерін топтастырсақ, мына ұстанымның төңірегінен табылар еді.

Біріншіден, ғылыми атауларды сұрыптауда, шет жұрттан алынған ұғымдарды төл тілімізге барынша жақындатып, оған лайықты ат табу.

Екіншіден, термин жасауда төл тіліміздің өзіне тән ішкі зандылықтарын, яғни дыбыс жүйесіне қатысты өзекті жақтарын мықтап ескеру. 
Үшіншіден, шетел тілдерінен (Еуропа, араб, парсы т.б.) терминдер алғанда аса сақтықпен қарап, бұларды ала қойған жағдайдың өзінде әз тіліміздің айтылуына қарай икемдеп қолдану.

Төртіншіден, шетел тілдерінен алынған термин сөздерді қабылдауда орыс тілінің дәнекерлік рөл атқаратынын, яғни жалғастырушы болатынын әркез есте ұстау [5].

Ғұлама ғалымның психологиялық мұралары туралы айтқанда, біз оның осы мәселедегі негізгі желісі мына төмендегі қисындардың төңірегінен табылады деп ойлаймыз. Бұлар біртуар ғалымның психология саласындағы өзіндік орнын қайталанбас ерекшелігін жақсы байқатады.

\section{Әдебиеттер тізімі:}

1. Елбасы Н.Ә. Назарбаевтың «Болашаққа бағдар: рухани жаңғырту». Ақпараттық-түсіндірмелі материал. - Астана, 2017. 56б.

2. Әбиев Ж., Бабаев С., Құдиярова А. Педагогика. - А., 2004.

3. 3 Жарықбаев Қ., Қалиев С. Қазақ тәлім-тәрбиесі. -Алматы., 1995.

4. Қазақтың тәлімдік ой-пікір онтологиясы. І-том. Қ. Жарықбаев және т.б. A., 1994.

5. Жарықбаев Қ., Табылдиев Ә. Әдеп және жантану. - Алматы., 1994.

\section{ОКУШЫЛАРДЫН ЛИДЕРЛІК КАСИЕТІН ТӘРБИЕЛЕУДІН МҮМКІНДІКТЕРІ}

Әліпбек Ардақ Зәуірбекқызы п.в.к., дочент м.а., Оңтүстік Қазақстан мемлекеттік педагогикалық университеті, Қазақсстан, Шымкент

\section{Сманов Ілесхан Сманович}

n.z.d., профессор, Оңтүстік Қазақстан мемлекеттік педагогикалық университеті, Қазақстан, Шымкент 
Амирханова Гулимжан Нурадиновна

ава оқыытушы, магистр,

Онттүстік Қазақсттан мемлекеттік педагогикальқ университеті, Қазақ̆стан, Шымкент

\title{
Искендар Марат Оралбекұлы
}

5В010300 - Педагогика және психология мамандыгы,

5-курс студенті,

Онттүстік Қазақстан мемлекеттік педагогикальқ университеті,

Қазақсстан, Шымкент

\begin{abstract}
АННОТАЦИЯ
В этой статье рассматривается вопрос о воспитании лидерства учащихся в учебно-воспитательной системе - психолого-педагогический. Здесь также анализируется понятие «лидерство» с точки зрения философских, педагогических, психологических, социологических наук.

\section{ABSTRACT}

This article examines the issue of raising the leadership of students in the educational system - psychological and pedagogical. It also analyzes the concept of «leadership» from the point of view of philosophical, pedagogical, psychological, sociological sciences.

Республикадағы әлеуметтік-экономикалық жағдайдың өзгеруі, қоғамдық құрылыстың ауысуы, ерікті, табанды, тәуелсіз, белсенді, сауатты, ақпараттанған, жаңа буынның адамын талап етті. Өзінің соңынан адамдарды ертіп жүре алатын тұлғаға, жаңа буынның адамына әлеуметтік тапсырыстың пайда болуына себепші болды. Өзі үшін ғана емес, өздері жүрген топ үшін де жауап бере алатын, моральды-этикалық принциптердің сақталуына, өздерінің істеріне жауапты адамдарға сұраныс артты. Өз заманының сұранысына сай жаңа адамға деген қажеттілік, жауапкершілікті ала білуге қабілетті тұлғаны дамыту, оқушы жастарды лидерлікке тәрбиелеу тәсілдерін өзгертті. Осы өзгерістер салдарынан, жаңа буын лидері шынайы құндылықтарды таратушы болуы қажет, ол өз мүмкіндіктерін жүзеге асыра алуы, айналасындағы жас адамдардың әлеуетін аша білуі, өзгерістерге бейімделуі мен қажетті шешімдер қабылдай алуы тиіс [1].

Бұл жағдай, қоғамнан лидерлік мәселесін қайта ойланып қарастыруды талап етеді. Жалпы лидерлік әлеуметтік құбылыс ретінде
\end{abstract}


қоғамның барлық саласынан орын алып отыр. «Лидерлік» түсінігі философияда, педагогикада, психологияда, әлеуметтануда, саясаттануда және өзге де адамтану мен қоғамтануға қатысты ғылымдарда зерттеліп, бірқатар ғасырлар бойы ғалымдардың зерттеушілік қызығушылығын арттырып келеді.

Лидерлік мәселесінің зерттелуі антикалық философиядан (Аристотель, Платон) бастау алып, орта ғасырдағы философтардың діни білімдерінде өз жалғасын тапқан. Олар нағыз белсенділікке тек құдай ғана ие екендігін, ал, адам өз бастамасымен әрекет ете алмайтындығын айтады. Қайта жаңғыру дәуірінде Гегель тұлғаның лидерлік жағдайын бостандық көзі ретінде қарастырып, адамға алға қойған мақсатына жетуге әрекет етуге мүмкіндік береді деп, санады. Сол заманның ойшылдары Гельвеций, Дидро лидерлікты адамның өзіне деген сүйіспеншілігін және жеке қызығушылығын арттырудағы тұлға белсенділігінің түрткісі ретінде қарастырған [2]. «Лидерлік» феноменінің дербестігі көптеген теориялық тұжырымдамалардың пайда болуына алып келді. Лидерлікке қатысты ең алғашқы теориялардың бірі XX ғасырда пайда болды. Оның пайда болуы ағылшын антропологы, психологы Ф.Гальтон еңбектерімен байланыстырылады. Ол лидерлік феноменін тұқым куалаушылықпен түсіндіреді. Теория жақтаушыларының пайымдауынша адамға лидерлік жүре емес, туа бітеді [3]. Мұнда, лидерлік ұғымы психологиялық феномен тұрғысынан түсіндіріледі.

Жиырмасыншы ғасырдың 30-шы жылдарында батыстың әлеуметтік психологиясында бұл феноменге көп көңіл бөлінді. Америка Құрама Штатының ғалымы К.Левин бастаған топ «лидер» және «лидерлік» ұғымын әлеуметтік психологиядағы динамикалық тұтастылық ретінде қарастырды. Олар мінез-құлық тұлғаның өзара әрекеті мен жағдайының нәтижесі деп қарастырды [4].

Мұндай пікір лидерлердің туа пайда болмайтынын вана емес, оны топта тәрбиелеу мүмкіндігін де білдіреді. Демек лидерлік, әлеуметтік-психологиялық феномен болып табылады.

Осыған байланысты ғылыми әдебиеттерде лидерліктің әлеуметтік және психологиялық теориялары қалыптасты. Олардың арасынан біз болмыс теориясын (харизматикалық тәсіл), лидер рөлін анықтау теориясын, жавдаяттық теорияны, кешенді теорияны қарастырамыз (кесте 1). 
Kecme 1.

Лидерлік теориялары

\begin{tabular}{|c|c|c|}
\hline $\begin{array}{c}\text { Теориялар } \\
\text { атауы }\end{array}$ & Теориялар мазмұны & $\begin{array}{c}\text { Теориянын } \\
\text { негізін } \\
\text { салушы }\end{array}$ \\
\hline $\begin{array}{l}\text { Болмыс теориясы } \\
\text { (харизматикалық } \\
\text { тәсіл) } \\
\end{array}$ & $\begin{array}{l}\text { Лидер болып адам туылады. Лидерлікке тұқым } \\
\text { қуалаушылық тән. }\end{array}$ & Ф.Гальтон \\
\hline $\begin{array}{l}\text { Лидер рөлін } \\
\text { анықтау теориясы }\end{array}$ & $\begin{array}{l}\text { Лидер - бұл ерекше рөлді қабылдаушы, } \\
\text { (біріншісі - кәсіби рөл, екіншісі - әлеуметтік- } \\
\text { эмоционалдық рөл). }\end{array}$ & Р.Бейлз \\
\hline Жағдаят теориясы & $\begin{array}{l}\text { Лидерлік - топтағы құрылған жағдайдың өнімі, } \\
\text { белгілі бір жағдаятта беделдікке ие болған } \\
\text { адам, лидер болады. }\end{array}$ & Ф.Фидлер \\
\hline Кешенді теориясы & $\begin{array}{l}\text { «Болмыс теориясын», «жағдаяттық теориясын» } \\
\text { және «лидер рөлін анықтау теориясын» бірге } \\
\text { қосқан кешенді теория. Лидерлік - бұл } \\
\text { тұлғааралық қатынастарды ұйымдастырушы } \\
\text { үрдіс, ал лидер - осы үрдісті басқарушы } \\
\text { субьект. }\end{array}$ & В.Белл \\
\hline
\end{tabular}

«Болмыс теориясы» лидерны өзіндік қасиетіне тән негіздейді, яғни лидерліктің негізгі детерминанты болып, қайталанбас лидерлікке туылғаннан ие болу табылады. Яғни «болмыс теориясына» сәйкес кезкелген адам лидер бола бермейді, адам лидер болып туылады [5].

Лидерліктің болмыс теориясын жақтаушылар адамды лидер ретінде танудың алғышарттары деп олардың тума қасиеттерін және индивидтің сипатын (күшін және жүйке үрдісінің қозғалмалылығын, экстраверттілігін, эмпатияға қабілеттілігін, анық көрінетін эвристикалық және интеллектуалдық қабілеттерді) санайды. Мұндай қасиеттер оларға кез-келген жағдайларды басқаруға және жетекшілік етуге, яғни лидер рөлін өз қолына алуына жол ашады.

Әлеуметтануда адамның осындай өзіне тән ерекше қырын атау үшін арнайы термин енгізілді. «Харизма» түсінігін ғылыми айналымға неміс әлеуметтанушысы, тарихшы, экономист және юрист М.Вебермен енгізген [6]. Сонымен біз «харизма» деп ерекше лидерлік қасиеттер және лидерлердің іс-әрекет сипаттамасының жиынтығын айтамыз, сонымен қатар өзіндік бір жеке ерекшелігімен лидерлердің өзгелерге әсер ете алу қасиетін түсінеміз. 
Е.В. Абашкина аталван валымдардың еңбектеріндегі лидерлардың сипатына жан-жақты талдау жасай отырып, былайша жинақтап көрсетедi:

- ізбасарлары тарапынан қолдау табуы;

- өзіне деген сенімділігі;

- күтілген нәтижеге жетуге сенімділігін көрсете алуы және ол туралы айналасындағыларға түсінікті және жүйелі түсіндіре алуы;

- өз адамдарына дем беріп, рухтандыру үшін жеткілікті оптимизмі мен сенім қорының болуы;

- жігерлілігі, мінезінің жұмсақтығы;

- көңіл күйдің орнықтылығы.

Е.В. Андриенко лидер болып қандай да бір ерекше қасиетке ие адамдар ғана бола алады деудің еш негізі жоқ дей отырып, бірақ дәл осы теорияның психологиялық және практикалық маңыздылыққа ие екендігін жоққа шығармайды [7].

Сонымен, ғалымдардың осындай пікір таластыруларынан кейін лидер рөлін анықтау теориясы пайда болады.

«Лидер рөлін анықтау теориясын» американдық зерттеуші Р. Бейлз негіздеген. Р.Бейлз лидер - бұл ерекше рөлді қабылдаушы деп көрсетеді. Бұл теорияны Т.Ньюк, А.Харе де қолдады. Олар бірнеше топта бір адам әр түрлі рөлді ойнайды және түрлі орынды иемденуі мүмкін деп көрсетті. Олардың пікірінше, лидерлік тұлғаның немесе топтың атқаратын қызметін емес, оның әр түрлі жағдайларға тап болғанда күрделі және көпжоспарлы ықпал ету нәтижесін білдіретіндігін түсіндіреді.

Олар лидерлердің бір-бірінен ерекшеленетін екі түрін атап көрсетедi:

Біріншісі - жұмысты орындау барысында пікірлерін, ұсыныстарын білдіру мен мәселелерді шешуге байланысты кәсібилік рөлі.

Eкіншісі - адами қарым-қатынас мәселесін шешуге қатысты «әлеуметтік- эмоционалдық маман» рөлі. Топтың әрекетінің жемісті және тиімді болуы үшін лидерліктің осы екі түрі де болуы қажет.

Сонымен, лидер, лидерлік мәселесі қарастырылған психологиялықпедагогикалық еңбектерге жасаған талдау лидер, лидерлік феноменінің әдебиеттерде жан-жақты талданғанын, бірқатар лидерлік теориялардың (болмыс теориясы, жағдаяттық теория, лидер рөлін анықтау теория, кешенді теория және т.б.) қалыптасқандығын көрсетті.

\section{Әдебиеттер тізімі:}

1. Baikulova A.M., Ibrayeva M.K., Shalabayeva L.I., Abdigapbarova U.M., Mynbayeva A.P. The System of Development Programmes on Pre-School and School Education in the Republic of Kazakhstan // Interchange. - 2016. - №1. P. 1- 16. 
2. Андреева Г.М. и др. Зарубежная социальная психология ХХ столетия: Теоретические подходы: учебное пособие для вузов. - М.: Аспект-Пресс, 2006. - 288 c.

3. Гальтон Ф. Наследственность таланта, её законы и последствия / пер. с англ. - СПб., 1875. -299 с.

4. Ашин Г.К. Критика современных буржуазных концепций лидерства. -М.: Мысль, 1978. - 135 с.

5. Вебер М. Харизматическое господство. Психология и психоанализ власти. Хрестоматия. - Самара: Издательский дом «Бахрах», 1999. -Т.2. - С. 55- 68.

6. Stogdill R.M. Handbook of Leadership. A survey of theory and research. N.Y., 1974. -362 p.

7. Абашкина Е.Б., Косолапова Ю.Н. О теориях лидерства в современной политической психологии США // Экономика, политика, идеология. 1995. -№1. - C. 75-81. 


\title{
O'ZBEK TILIDAGI KONFERENTSIYA MA'RUZALARI
}

\author{
PEDAGOGIKA
}

\author{
1 -BO'LIM \\ GENERAL PEDAGOGIKA, \\ PEDAGOGIKA VA TA'LIM TARIXI
}

\section{TALABALARDA AKADEMIK MOBILLIKNI RIVOJLANTIRISH}

Shermanova Diyora Shakarboyevna

Samarqand davlat universiteti pedagogika fakulteti

1-bosqich magistranti,

$O$ 'zbekiston, Samarqand

So'nggi bir necha asrlarda ijtimoiy ishlab chiqarish va tsivilizatsiya rivojlanishidagi taraqqiyot fan va ta'lim yutuqlari bilan bog'liq edi. Ta'lim nafaqat shaxsning sotsializatsiyasi va ijtimoiy-madaniy integratsiyasining muhim omillaridan biri, balki shaxsning ijtimoiy kapitalini rivojlantirish, uning ijtimoiy-iqtisodiy harakatchanligi darajasini oshirishning samarali vositasidir. Bizning davrimizda ta'limning genezisida muhim omil bo'lib, uning rivojlanish maqsadlarining aksi bo'ldi: milliy ta'limni takomillashtirish, global ta'lim makoniga integratsiya qilish, turli maktablarning bilimlari, texnikasi va usullari bilan almashish, yo'nalishlar, dunyoning umumiy qarashlarini shakllantirish, uni saqlab qolish va qayta qurish. Shuning uchun zamonaviy ta'lim makoni va ta'lim jarayonining ijtimoiy jihatlarini sotsiologik tahlil qilish insoniyat jamiyati rivojlanishining har qanday bosqichida dolzarbdir.

Har qanday ijtimoiy harakat to'siqsiz emas, balki ozmi-ko'pmi muhim to'siqlarni engib o'tish orqali amalga oshiriladi.

Shaxs yoki ijtimoiy guruhning barcha ijtimoiy harakatlari harakatchanlik jarayoniga kiritilgan.P. Sorokin ijtimoiy harakatchanlik deganda shaxs 
tomonidan yoki ijtimoiy ob'ekt yoki qiymat orqali yaratilgan yoki o'zgartirilgan, har qanday ijtimoiy pozitsiyadan boshqasiga o'tishi tushuniladi.

\section{- Talabalarning xalqaro akademik harakatchanligi nima?}

$\mathrm{Bu}$ talabalarning o'qish joyiga tashrif buyurgan holda chet el universitetida asosiy fakultetdan tashqari kunduzgi o'qitish, shuningdek, ishtirok etish bahosi kreditda ko'rsatilgan va sertifikatda taqdim etilgan qisqa seminarlarda, yozgi / qishki maktablarda qatnashishdir. Xalqaro akademik harakatchanlik doirasida chet elda o'qish uchun borgan talabalar chet el universitetlarida o'qish natijalarini qaytarmasdan kredit olishlari mumkin. Ya'ni, chet el universitetida to'g'ri tanlangan kurslarni qabul qilib, imtihonlarini muvaffaqiyatli topshirganingizdan so'ng, safaringizdan keyin MIEMga bir qator qarzlarni topshirishingiz shart bo'lmaydi.

Akademik mobillik dasturlarida HSE talabalarining ishtiroki tartibga solinadi (agar siz ushbu dasturda qatnashmoqchi bo'lsangiz, O'QING).

Uzoq muddatli akademik mobillik dasturlariuniversitetlararo shartnomalar bo'yicha HSE tomonidan markazlashgan holda tashkil etilgan veb-saytda joylashgan. Yangiliklarni kuzatib boring, yiliga 2 marotaba ushbu dasturlarda qatnashish uchun arizalarni qabul qilish muddati e'lon qilinadi.

Arizani rasmiylashtirish uchun zarur bo'lgan hujjatlar ro'yxatini quyidagi manzilda topishingiz mumkin.

Shuningdek, siz chet elda qisqa muddatli o'qishni mustaqil ravishda tashkil qilishingiz mumkin, masalan, chet el universitetining yozgi tematik maktabida qatnashish uchun ariza yuborish orqali:

HSE chet elliklar uchun xuddi shunday yozgi maktabga ega:

Bu yanada jiddiy o'quv dasturlariga tayyorgarlik ko'rishga yordam beradi, fikrdoshlar bilan madaniyatlararo muloqotning unutilmas tajribasini va chet elda biznes (turistik bo'lmagan) qolish tajribasini beradi.

Bunday maktabda qatnashish uchun ariza tuzishingiz va o'zingiz qabul qilgan universitetga yuborishingiz kerak bo'ladi, ichki hujjatlar NRU HSE sizga kelganingizda yordam beradi.

Shuni ta'kidlash kerakki akademik harakatchanlik uchun eng "qulay" davrlar bu bakalavrning 2-kursi (siz allaqachon o'quv jarayoniga moslashganingizda) va 3-kursingiz (diplom oldidan hali vaqt yetganda). Magistraturada sizga 1-kursning 2-yarmi va 2-kursning 1-yarmini ko'rib chiqishingizni maslahat beramiz (unchalik ma'qul emas, GIAga o'z vaqtida kirmaslik xavfi mavjud).

Universitetning birinchi yilidanoq e'lon qilingan tanlov / arizalarni qabul qilishni boshlash / xalqaro grant uchun tanlovda ishtirok etishni taklif qilish uchun barcha to'plamni tez va oson yig'ish uchun qanday hujjatlarni tayyorlashingiz kerak? 
1. Sizning bilim darajangizni tasdiqlovchi sertifikat xorijiy til... Ha, ko'pincha xalqaro sertifikat talab qilinadi (inglizcha: IELTS, TOEFL, Kembrij sertifikati va h.k.). Bunday sertifikatni olish uchun siz maxsus sertifikatlangan markazda imtihon topshirishingiz kerak, sertifikatlarning amal qilish muddati boshqacha.

Bilasizmi, HSE Kembrij Xalqaro Ingliz tili imtihonlari KET, PET, FCE, CAE, CPE, BEC, TKT va ILEC imtihonlarini o'tkazishini bilasizmi ???

2. Xulosa yoki tarjimai hol yoki rezyume. Ingliz va rus tillaridagi ushbu hujjat bir marta to'planib, vaqt o'tishi bilan to'ldirilishi va o'zgartirilishi kerak. Bu sizga ko'p asab va harakatlaringizni tejashga yordam beradi.

3. Ingliz va rus tillaridagi nashrlarning ro'yxati, shuningdek, birinchi nashr olinganidan keyin tuzilishi kerak va uni to'ldirishni unutmang. $\mathrm{Bu}$ erda siz nafaqat ta'lim va ilmiy, balki olingan mukofotlar, sertifikatlar, sovg'alar to'g'risidagi ma'lumotlarni ham qo'shishingiz mumkin. Sportdagi yutuqlar va ijtimoiy faoliyat ko'plab grantlar, stipendiyalar va dasturlarda ular muhim rol o'ynaydi.

4. Qisqa Tasvir ingliz va rus tillarida o'zlarining o'quv, ilmiy va professional loyihalarida. Agar jiddiy narsa yo'q bo'lsa, unda siz tugatgan kurs ishining tavsifi, shuningdek amaliyot yoki yarim kunlik ish paytida olingan kasbiy mahorat bo'lishi kerak. Ulardan qaysi biri sizni qulay nurda mutaxassis sifatida taqdim etishi mumkinligini o'ylab ko'ring.

5. Ingliz tilidagi baholar bilan transkriptga buyurtma berishingiz kerak. Buni (sertifikatni buyurtma qilish) amalga oshirish mumkin.

6. Umuman olganda, o'tgan va o'qish davomida siz uchun keladigan barcha o'quv fanlari ro'yxatini qaerga qarashni bilasizmi? Sizga ish (1 yil davomida) yoki asosiy (butun davr uchun) o'quv dasturi kerak. Ular sizning o'quv dasturingiz veb-saytida, o'ng paneldagi "Hujjatlar" bo'limida joylashgan.

- Yana nimani yodda tutishingiz kerak?

Akademik harakatchanlik har doim ham chet elga sayohat qilishni anglatmaydi, shuningdek, "o'z uyida" xalqarolashuv deb ham ataladi: siz o'qituvchilar bilan muloqot qilish, xalqaro ishtirokchilar bilan seminar va konferentsiyalarda qatnashish orqali katta tajriba orttirishingiz mumkin. Siz (chet ellik talabani o'z qaramog'ingizga olishingiz) yoki til klubiga borishingiz mumkin:

Asosiysi, faol bo'lish. Axir global dunyoda zarur bo'lgan ishbilarmonlik, ilmiy va sodda do'stona aloqalar shu tarzda o'rnatiladi.

Oldingi ishtirokchilarning tajribasi akademik mobillik dasturlari. $\mathrm{Bu}$ erda siz o'zingizning ma'lumotingizni bilib olasiz. Bundan tashqari, siz allaqachon jarayonni bevosita biladigan yigitlar bilan uchrashishingiz va ular bilan muloqot qilishingiz mumkin.

akademik harakatchanlik, ta'lim sohasidagi xalqaro hamkorlik yo'nalishlaridan biri sifatida talabalar almashinuvi va o'qituvchilar Kadrlar 
tayyorlash, malaka oshirish, takomillashtirish maqsadida Belorusiya Respublikasi va chet davlat o'quv faoliyati... Shu bilan birga, bunday almashinuv, qoida tariqasida, tenglik asosida amalga oshiriladi va vaqtinchalik. O'qish yoki amaliyotni tugatgandan so'ng, akademik almashinuv ishtirokchilari o'z universitetlariga qaytib kelishadi va u erda o'qishni yoki kasbiy faoliyatini davom ettirishadi ("akademik mobillik" tushunchasining ta'rifi va uni amalga oshirish shakllarining tavsifi Belorusiya Respublikasi Ta'lim kodeksida keltirilgan).

Shuni ta'kidlash kerakki, ba'zida akademik harakatchanlik diplom olish uchun chet el universitetlarida o'qish deb ham tushuniladi. Bu mutlaqo to'g'ri emas. Akademik almashinuv ta'lim jarayoniga xalqaro tarkibiy qism kiritilganda, ta'limni baynalmilallashtirish g'oyasiga asoslanadi. Har bir mamlakatning o'ziga xos akademik an'analari bor va chet el universitetiga tashrif buyurib, inson o'z vakolatlarini o'z mamlakatida bo'lmagan, o'z universitetida bo'lmagan narsalar bilan to'ldirish imkoniyatiga ega bo'ladi. Shu bilan birga, qo'shimcha xalqaro malakalarni olish uyda ta'lim traektoriyasiga kiritilgan.

Xalqaro ta'lim bo'yicha ixtisoslashgan adabiyotlarda akademik mobillik tushunchasidan tashqarida diplom olish uchun chet elga o'qish uchun sayohat qilishni ko'rib chiqish odat tusiga kiradi. Ushbu kontseptsiya asosida aynan chet el universitetida vaqtincha qolish, keyinchalik o'z mamlakatiga qaytish tushuniladi. Buning uchun "chet elda o'qish bilan bog'liq tajribalar / chet elda o'qish bilan bog'liq tajribalar" maxsus atamasi "xorijiy ta'lim tajribasi" ishlatiladi.

\section{Adabiyotlar ro'yxati:}

1. Abdullayeva B.S. Fanlararo aloqadorlikning dolzarb muammolari // "Texnikaviy va ijtimoiy-iqtisodiy fanlar sohalarining muhim masalalari" mavzusidagi Oliy o'quv yurtlariaro ilmiy ishlar to'plami. Toshkent: TDTU, 2005, 161-164 betlar.

2. Azizxo'jayeva N.N. Pedagogik texnologiya va pedagogik mahorat. -Toshkent: TDPU, 2003, -175 bet.

3. Barkamol avlod orzusi. //Tuzuvchilar: Sh.Qurbonov, R. Axliddinov, H.Saidov. Toshkent: "Sharq", 1999 -205 bet.

4. Ziyomuxamedov B. Abdullayeva Sh. Ilg' or pedagogik texnologiya. Nazariya va amaliyot. - Toshkent: Abu Ali ibn Sino nomidagi tibbiyot nashriyoti, 2001, 80-bet.

5. Yo'ldoshev O'. Didaktik prinsiplar tizimi. //“Xalq ta'limi” jur. 2002, 4-son, 20-bet.

6. Roziqov O. va boshqalar. Ta'lim texnologiyasi. - Toshkent: "O'qituvchi", 1999. -71 bet.

7. Taylaqov N.I. Ta'lim tizimida zamonaviy axborot texnologiyalarini joriy etishning istiqbollari// "Ta'lim va tarbiya” jurnali. -Toshkent: 2002, 1-2 sonlar. 27-30 betlar. 


\title{
2-BO'LIM
}

\section{KASB TA'LIMI NAZARIYASI VA METODIKASI}

\section{AMALIY MASHG'ULOTLARDA SIMULYATORLAR BILAN ISHLASH}

\author{
Musamedova Kamola Abdulxakovna \\ Erkin izlanuvchi \\ Toshkent davlat transport universiteti, \\ O'zbekiston, Toshkent
}

\begin{abstract}
ANNOTATSIYA
Ushbu ishda asbob-uskuna va jihozlarsiz virtual holatda biror bir fizik jarayonni modellashtirish hamda virtual laboratoriya ishlarini o'tkazishga imkoniyat yaratadigan simulyatorlarni imkoniyatlari ko'rib chiqilgan.
\end{abstract}

Kalit so'zlar: simulyator; modellashtirish; dasturiy ta'minoti.

Simulyatorlar o"quv jarayoning qariyb barcha jabhalarida: boshlang ich ta'limdan boshlab, oliy o'quv yurtlarigacha qo'llanilishi mumkin. Keyingi vaqtlarda xattoki meditsina sohasida ham simulyatorlardan foydalanilmoqda. Simulyatorlardan foydalanishning asosiy sabablaridan biri ularning real ob'ektlarga nisbatan juda ham arzon alternative ekanligidadir. Simulyatorlar esa shunday haqiqiy asbob-uskuna va jihozlarsiz virtual holatda biror bir fizik jarayonni modellashtirish hamda virtual laboratoriya ishlarini o'tkazishga

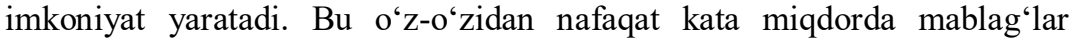
tejalishiga, balki ularga umuman ehtiyoj ham tug'dirmaydi. Simulyatorlarning qariyb hech qanday moliyaviy mablag'lar talab etmasligi ma'lum tadqiqotlarni talabalar tomonidan yuzlab, kerak bo'lsa minglab marotaba qayta-qayta amalga oshirishga imkoniyat yaratadi.

Simulyatorlardan foydalanishning yana bir afzallik tomoni ularning xavfsiz ekanligidadir. Ba'zi tadqiqotlarni amalga oshirish inson hayoti uchun xavf tug'diradi, masalan, yadro fizikasiga oid bo'lgan hodisalarnio'rganish. Bunday tadqiqot kata miqdorda moliyaviy xarajat talab etibgina qolmasdan, tadqiqotni olib boruvchilar uchun hayotiga xavf ham tug'diradi. Simulyatorlardan foydalanish jarayonida talabalar ma'ruza vaqtida o'rgangan bilimlarini virtual bo'lsada hayotga tadbiq qiladilar. Ushbu tadqiqotlar 
jarayonida bilimlarini yanada mustahkamlash bilan bir qatorda nazariya hamda hayotiy tadbiqotlarning rivojlanishiga bevosita xissa qo'shadilar [110]. Bundan tashqari o'sha simulyatorlarning ham yanada rivojlanishiga, yanada haqiqiy hayotiy tadqiqotlarga yaqin natijalar beradigan darajaga chiqarishda o'z xissalarini qo'shishlari mumkin. Bu o'z o'rnida talabalarni faqatgina "tinglovchi” vazifasida qolmasdan, bevosita ilmiy-tadqiqot ishlarida qatnashuvchilarga aylantiradi. Bu esa o'z navbatida talabalarda o'qish va tadqiqotlarga bo'Igan qiziqishlarini yanada ortishiga olib keladi [11-18].

Tabiiy fanlar yo'nalishida 2001 yildagi Nobel mukofotining laureate K. Viman tomonidan «Physics Education Technology» $(\mathrm{PhET})$ sayti yaratilgan. PhET saytida har xil mavzularga oid modellar mavjud bo'lib, ular Java va Macromedia flash dasturlarida yaratilgan.PhET saytida taqdim etilayotgan modellar Open Sourse bo'lib, xohlagan foydalanuvchi bepul foydalanishi mumkin. PhET dagi modellar soni 100 dan ortiq bo'lib ular fizika, matematika, kimyo fanlariga oid namoyish tajribalarini o'tkazish, virtual laboratoriya ishlarini tashkillashtirish va modellashtirish imkoniyatiga ega. Bu PhET dasturi O'zbekiston davlat ta'lim standartlariga va o'quv muassasalarida qo'llanilayotgan adabiyotlariga mos keladi. PhET dasturini http://phet.colorado.edu saytidan ko'chirib olishingiz mumkin.PhET dasturidagi modellardan fizika, matematika, ximiya va biologiya fanlaridan dars mashg'ulotlarida namoyish tajribalari sifatida, virtual laboratoriya mashg'ulotlarini tashkillashtirishda keng foydalanish mumkin.

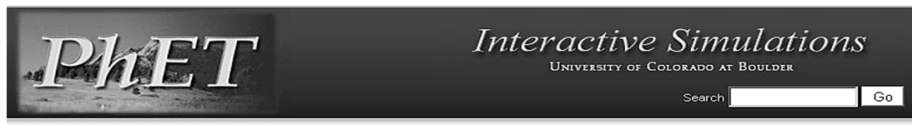

What's New I Ahout PhET

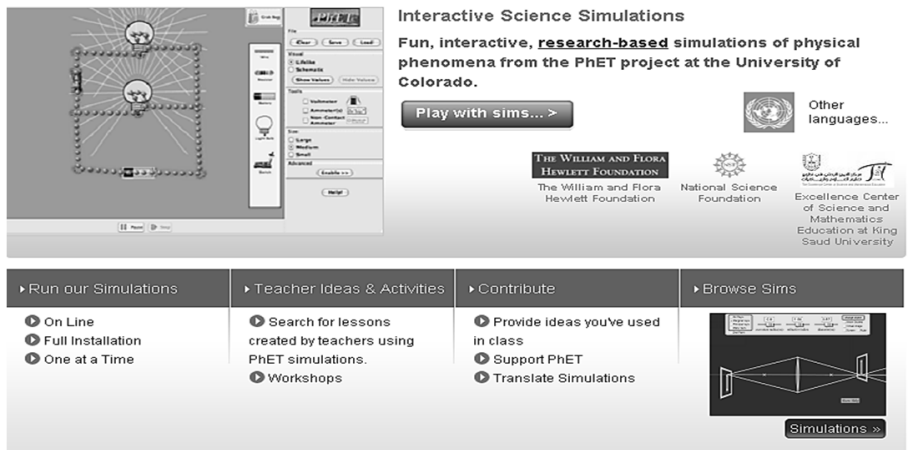

C 2009 University of Colorado. Some rights reserved

1-rasm. PhET dasturining umumiy ko'rinishi 
Dasturda keltirilgan modellarni faqat ingiliz tilida emas. Balki 50 dan ortiq tilga tarjimalarini toppish mumkin, xususan o'zbek tilida 1 ta model tarjima qilingan. Agar siz dasturda keltirilgan modellarni o'zbek tiliga tarjima qilishni hoxlasangiz, xech qanday qiyinchiliksiz bu niyatingizni amalga oshirishingiz mumkin.

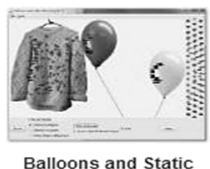

Balloons and Static Electricity

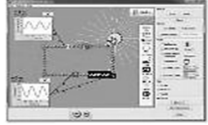

Circuit Construction Kit $(A C+D C)$



Generator

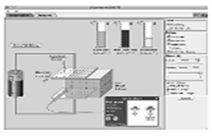

Capacitor Lab



Magnet and Compass



Electric Field Hockey

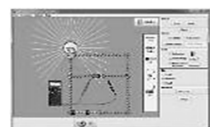

Circuit Construction Kit (DC Only)



Magnets and Electromagnets



Charges and Fields

2-rasm. PhET dasturida mavjud modellarning ko'rinishi

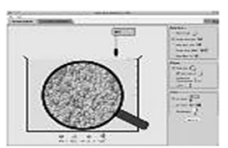

Acid-Base Solutions

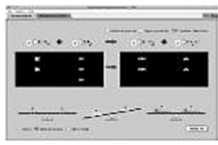

Balancing Chemical Equations

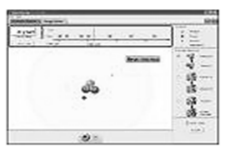

Beta Decay



Alpha Decay

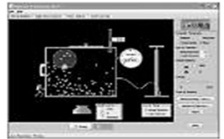

Balloons \& Buoyancy



Blackbody Spectrum

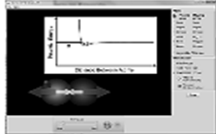

Atomic Interactions

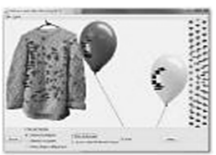

Balloons and Static Electricity

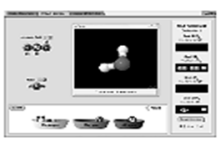

Build a Molecule

3-rasm. PhET dasturida mavjud modellarning ko'rinishi 
Buning uchun dasturning rasmiy saytida "Translated Sims" bandi mavjud bo'lib, u yerga kirib maxsus qaydnomani tuldirgan holda tegishli modelni tanlab o'zbek tiliga tarjima qilishingiz mumkin.PhET dasturida har xil fanlar kesimidagi modellarning ko'rinishini qo'yidagi rasmda ko'rishimiz mumkin.PhET dasturining rasmiy http://phet.colorado.edu saytining "O'qituvchilar uchun" bandida har bir model uchun metodik ko'rsatmalar (virtual laboratoriya ishlari, namoyish tajribalari va boshq.) keltirilgan.

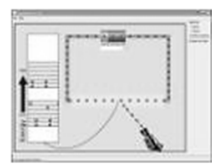

Conductivity

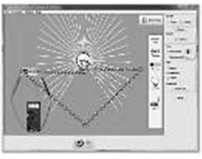

Circuit Construction Kit (DC Only), Virtual Lab

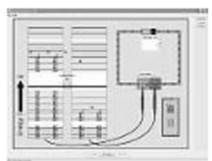

Semiconductors

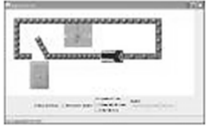

Signal Circuit

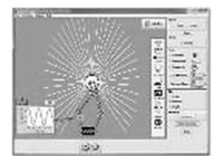

Circuit Construction Kit $(A C+D C)$, Virtual

Lab

4-rasm. PhET dasturining “Elektr va magnitezm” bo'limiga oid modellar

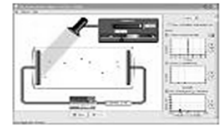

Photoelectric Effect

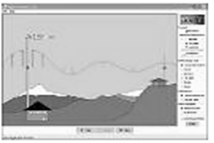

Radio Waves \& Electromagnetic Fields

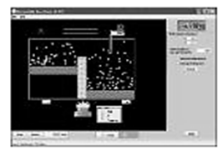

Reversible Reactions

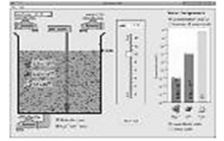

pH Scale

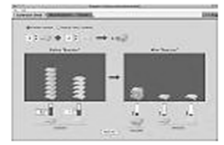

Reactants, Products and Leftovers

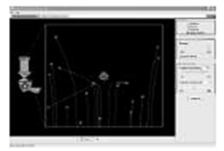

Rutherford Scattering

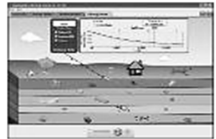

Radioactive Dating Game

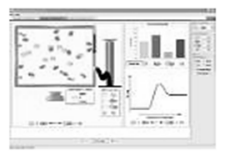

Reactions \& Rates

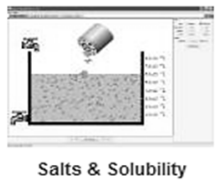

5-rasm. PhET dasturida mavjud modellarning ko'rinishi 
O'qituvchi xech qanday qiyinchiliksiz qo'yidagi qidiruv filtri orqali mavzuga oid dars ishlanasini yoki metodik ko'rsatmalarni, ta'lim turi kesimida pdf yoki doc formatlarida ko'chirib olishi mumkin.Crocodile Clips Ltd simulyatorlari bilan ishlash.Crocodile Clips Ltd o'zining yaratgan dasturlarini hozirda uy sharoitida (home licence) o'qituvchi va o'quvchilar (talabalar) bepul foydalanishlari uchun imkoniyat yaratdi.

Shuni ta'kidlab o'tamizki, hozirda Crocodile kompaniyasi dasturiy ta'minotlarini Yenka nomi bilan takomillashtirilgan holda yaratildi. Hozirda bu dasturlar Yenka nomi bilan chiqmoqda, lekin dasturlarning ishlashi Crocodile dagidan farq qilmaydi.Endi shu dasturiy ta'minotlar bilan tanishib chiqamiz. Crocodile Technology dasturiy ta'minoti haqida.Bu dasturdan o'rta maktab o"quvchi va o'qituvchilari, litsey, kollej talabalari va oliy ta'lim muassasalarining talaba, professor-o"qituvchilari «Elektr», "Elektrotexnika", "Sxemotexnika", "Elektr zanjirlar nazariyasi" fanlarida qo"shimcha pedagogic dastariy vosita sifatida keng foydalanishlari mumkin.

- Dastur electron konstruktor bo'lib, u monitor ekranida elektr sxemalarini yig'ish jarayonini xuddi haqiqiy tajribadagi singari imitatsiya qilish, elektr kattaliklarni multimetrda (3 o'lchovli), ampermetr va voltmetrlarda o'lchash imkoniyatini beradi. Masalan, dasturda: Mikroprotsessorlarni dasturlash va robototexnikaga oid modellarning 3D ko'rinishda simulyatsiyalashtirish mumkin. Konstruktor detallarining tasviri va o'lchov asboblarining sxematik va haqiqiy ko'rinishda berilgan;

- Qarshilikdan oqib o'tayotgan tok quvvatining qiymati berilgan nominaldan ortib ketsa, qarshilik (portlab) kuyadi, bu esa ekranda uning rangi o'zgarib qoraygan detal ko'rinishiga o'tishi bilan ko'rsatiladi; Lampochka va elektr isitgich asboblari quvvatning nominal qiymatida yorqinlashadi, agar ulardagi quvvat ishchi qiymatidan ortib ketsa kuyadi va bu asbob ekranda qorayib qoladi. Xuddi shuningdek ekranda boshqa detallardagi fizikaviy kattaliklarning o'zgarishi imitatsiya qilinadi;

- Ko'pgina jarayonlar va ularning natijalari tovushli effektlar orqali ifodalanadi. Bularning barchasi, talaba o'zi yo'l qo'ygan xatolarini ko'rishi, muvaffaqiyatsiz bajarilgan tajribaning sabablarini aniqlashni o'rganishi va elektr sxemalarini tajribani haqiqiy qurilmalarda bajarishdan oldin tahlil qilish ko'nikmalarini hosil qilish imkonini beradi.

Shunday qilib, bu dastur, kasbi kim bo'lishidan qat'i nazar foydalanuvchini izlanuvchanlikka, ijodiy fikr yuritishga, ish natijalarini tahlil qilishga o'rgatadi. Dastur imkoniyatlari juda keng bo'lib, undan amaliy mashg'ulotlarda (ya'ni masalalar yechishda) ayniqsa, virtual laboratoriya ishlarini bajarishda keng foydalanish mumkin. 


\section{Adabiyotlar ro'yxati:}

1. Халиков А.А. Ўқитишни ташкил этиш услуби. / Институт кафедраларнинг $\mathrm{XXV}$ илмий - услубий анжумани (17-18 апрел 2008 йил). Тезислар тўплами. Тошкент- 2008. -С. 15-16.

2. Халиков А.А., Айнакулов Э.Б. Методика преподавания технических дисциплин с применением символьной обработки информации. / Институт кафедраларнинг XXV илмий - услубий анжумани (17-18 апрел 2008 йил). Тезислар тўплами. Тошкент- 2008. -С. 126-128.

3. Халиков А.А., Мусамедова К.А. Ўкув фаолиятини эффективлиги ва унга таъсир этувчи омиллар. // “Таълим муаммолари журнали”. Олий таълим вазирлиги. Тошкент - 2011. - №3. -С. 112-114.

4. Халиков А.А. Ўқиш жараёнида телекоммуникация технологиялари. /Институг кафедраларининг 27-илмий-услубий анжумани тезислар тўплами.ТТЙМИ. 10-11б. Ташкент- 2012. -С. 10-11.

5. Xalikov A.A. Kasb ta'limi metodikasi. / Kasb ta'limi metodikasi fanidan amaliy mashg'ulotlarni bajarishga doir uslubiy ko'rsatma. TTYMI. Toshkent2012. $-112 \mathrm{c}$.

6. Халиков А.А. Ихтисослик фанларини ўқитиш методикаси./ Магистратура мутахассислиги учун ўкув кўлланма. Тошкент- 2016. -148 с.

7. Халиков А.А., Ибрагимова О.А., Мусамедова К.А. Анализ методов дистанционного обучения и внедрения дистанционного обучения в образовательных учреждениях. // Вестник научных конференций. №36(19). Часть 6. Тамбов-2017. -С. 171-173.

8. Мусамедова К.А., Ибрагимова О.А. Олий таълимда инновация. Журнал Интернаука. №1 1(140). Часть2. Москва-2020. -С. 47- 48.

9. Xoliqov A. Pedogagik mahorat. Toshkent. 2010. $-120 \mathrm{c}$.

10. Халиков А.А., Мусамедова К.А. Электронная педагогика в учебном процессе. // UNIVERSUM: Психология и образование. № 4(70). Москва2020. №4(70). -C. 13-16.

11. Xalikov A.A., Rixsiev D.X., Kolesnikov I.K. Zamonaviy raqamli optik aloqa vositalari. / Oquv qollanma «Complex print» nashriyoti Toshkent-2018. 424 b.

12. Xalikov A.A., Davronbekov D.A., Kurbanov G.F. Raqamli mobil aloqa vositalari. Darslik. Toshkent-2018. «Faylasuflar nachriyoti». 556 b.

13. Халиков А.А., Мусамедова К.А. O'quv jarayonida pedagogik texnologiyalardan foydalanish. Журнал Интернаука. №12(141).Часть 3. Москва-2020. -С. 65-66.

14. Мусамедова К.А. Модуляция в системе технологии дистанционного обучения. UNIVERSUM: Психология и образование. : электрон. научн. журн. 2020. №5(71).URL: http: // 7universum.com/ru/psy/archive/item/9287.Москва2020.-C.8-10. psy@7universum.com. 
15. Халиков А.А., Мусамедова К.А. Анализ реализации программы подготовки и переподготовки кадров специалистов на железнодорожном транспорте. UNIVERSUM: Психология и образование. № 5(71). Москва-2020. -С. 4-7. psy@7universum.com.

16. Khalikov A.A., Musamedova K.A. Modulation in the system of remote learning technology. //Международная конференция. «International Scientific Review of the Problems of philosophy, psychology and pedagogy». Boston. USA. 2020.CONFERENCE SITE: HTTPS: //SCINTIFIC-CONFERENCE.COM. info@p8n.ru. 
ДЛЯ ЗАМЕТОК 


\section{ПЕДАГОГИКА И ПСИХОЛОГИЯ В СОВРЕМЕННОМ МИРЕ: ТЕОРЕТИЧЕСКИЕ И ПРАКТИЧЕСКИЕ ИССЛЕДОВАНИЯ}

Сборник статей по материалам XLV международной
научно-практической конференщฺии

№ 3 (45)

Март 2021 г.

В авторской редакции

Мнение авторов может не совпадать с позицией редакции

Подписано в печать 26.03.21. Формат бумаги 60х84/16.

Бумага офсет № 1. Гарнитура Times. Печать цифровая.

Усл. печ. л. 8,38. Тираж 550 экз.

Издательство «Интернаука»

125424, Москва, Волоколамское шоссе, д. 108, цокольный этаж, помещение VIII, комн. 4, офис 33

E-mail: mail@internauka.org

Отпечатано в полном соответствии с качеством предоставленного оригинал-макета в типографии «Allprint» 630004 , г. Новосибирск, Вокзальная магистраль, 3 


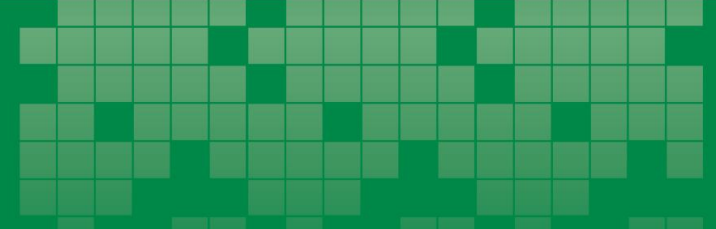

ООО «Интернаука» (г. Москва) проводит международные заочные научно-практические конференции по 26 научным направлениям. Предоставляя возможность опубликовать статьи быстро и качественно, мы помогаем аспирантам, соискателям и докторантам представить на суд научной общественности результаты проведенных исследований, открываем дорогу молодым, привлекаем в научную среду как начинающих ученых, так и профессионалов, имеющих богатый практический опыт в прикладной сфере и упрощаем процесс вхождения в научное сообщество, снижая барьеры расстояния, финансов, языка, статуса, возраста, опыта.

Мы проводим заочные конференции на ДВух языках: русском и английском, способствуя сближению научных сообществ разных стран.

Нашим изданиям присваиваются коды ISSN, УДК, ББК. Производится их регистрация в Российской книжной палате и рассылка по библиотекам нашей страны.

На сегодняшний день в рамках проекта "Интернаука" было проведено свыше 250 конференций, в которых приняли участие более 6000 ученых из 15 стран мира: России, Казахстана, Узбекистана, Азербайджана, Украины, Белоруссии, Польши, Армении, Латвии, Болгарии, Молдовы, Румынии, Эстонии, Греции, Турции.

ИНТЕРНАУКА

internauka.org

Конференции no 26

направлениям науки:

Архитектура

Астрономия

Биология

Ветеринария

География

Геология

Информационные технологии

Искусствоведение

История

Культурология

Математика

Медицина

Менеджмент

Педагогика

Политология

Психология

Сельскохозяйственные науки

Социология

Технические науки Фармацевтические науки

Физика

Филология

Философия

Химия

Экономика

Юриспруденция 